\title{
Birch Creek National Wild River, Alaska: Resource Values and Instream Flow Recommendations
}

Bunny B.G. Sterin, Doug Whittaker and Jon Kostohrys

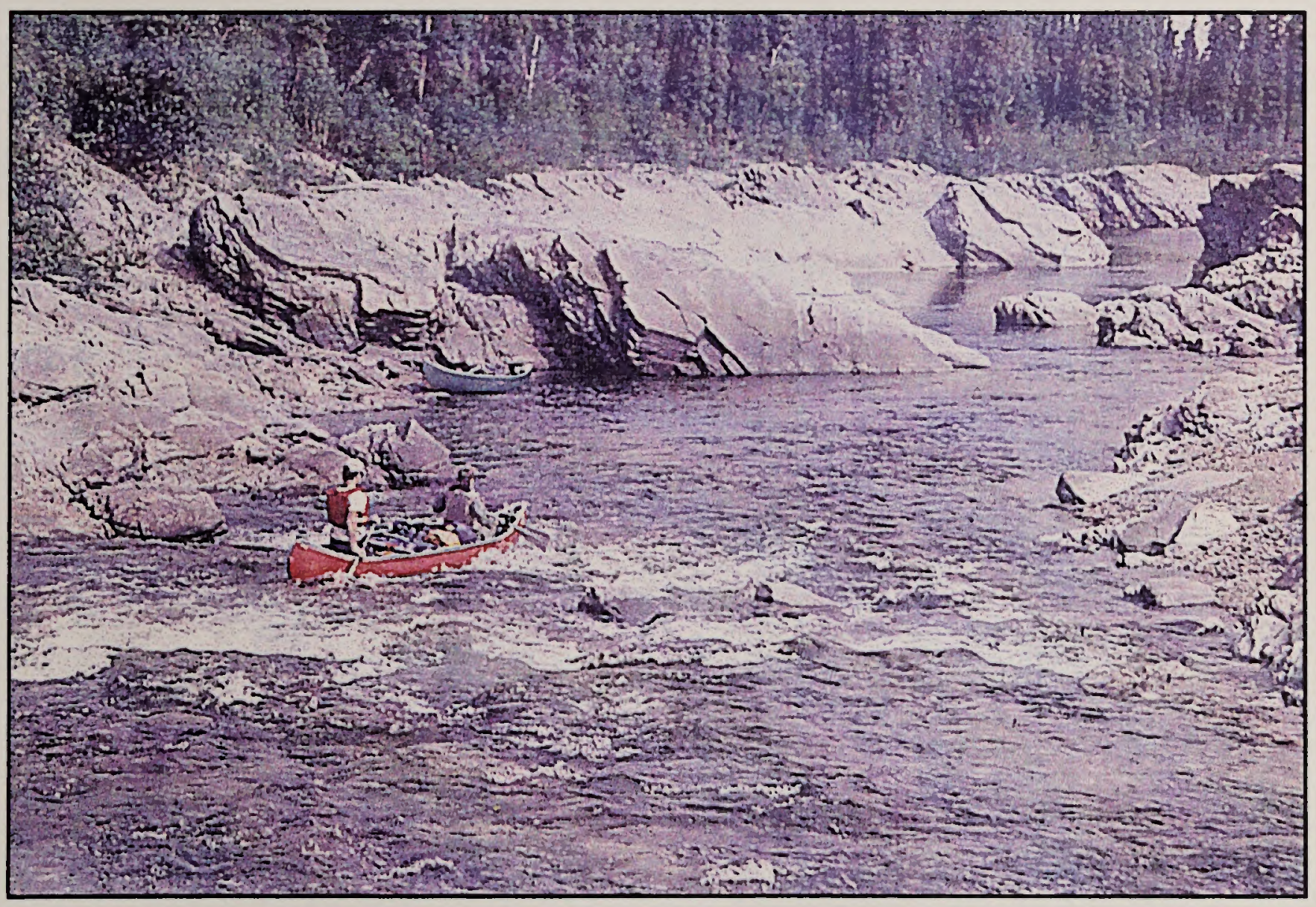


BLM LIBRARY

BLDG 50, ST-150A

DENVER FECERAL CENTER

P.O. BOX 25047

DENVER, COLORADO 80225 


\section{Birch Creek National Wild River, Alaska: Resource Values and Instream Flow Recommendations}

Bunny B. G. Sterin, Doug Whittaker and Jon Kostohrys

U. S. Department of the Interior Bureau of Land Management Alaska State Office 222 W. 7th Avenue, \#13 Anchorage, Alaska 99513 


\section{Cover Photo}

Birch Creek offers an enjoyable recreation experience for boaters.

\section{Authors}

Bunny B. G. Sterin is a hydrologist with the BLM Alaska State Office, Anchorage, Alaska Doug Whittaker is an outdoor recreation planner, formerly with the U. S. National Park Service. Jon Kostohrys is a hydrologist with the BLM Northern Field Office in Fairbanks, Alaska. 


\section{ACKNOWLedgments}

We appreciate the program support of Gene Terland, Interdisciplinary Group Administrator at the Alaska State Office, Bureau of Land Management; Richard Bouts, Associate District Manager; and Keith Woodworth, Natural Resource Specialist, both of the Northern District, Bureau of Land Management.

We also give special thanks to:

Jim Davis and family who provided much of the information for the recreation section;

Bo Shelby, Don Prichard, Wayne Svejnoha, Bruce Van Havern, Tom Boyd and Lon Kelly who participated as team members in the interdisciplinary flow assessment during the initial reconnaissance and data collection effort;

Ingrid Kacher, Carl Kretsinger, Brian Lubinski and Joe Webb of BLM and Christopher Estes of Alaska Department of Fish and Game, who provided their expertise and review on the fisheries segment;

Eric Yeager, Nate Collin, Jim Herriges, Randy Tracy and Ed Lee, BLM employees who endured frigid temperatures and impassable trails while assisting with the winter data collection;

Brian Bogaczyk, formerly of BLM, who assisted with the ripatian section;

Jack Mosby, who provided constant support and assistance from the National Rivers and Trails Association of the National Park Service; and

Jim Vohden and the late Scott Ray of the Alaska Division of Water, who worked cooperatively on the basinwide Birch Creek hydrology data collection effort. 


\section{Table of Contents}

Acknowledgments iii

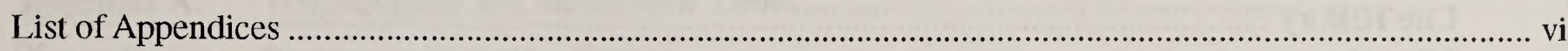

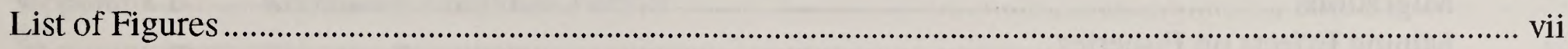

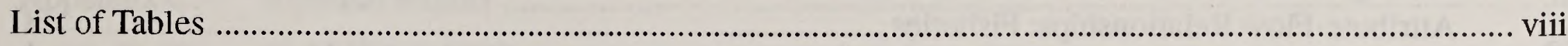

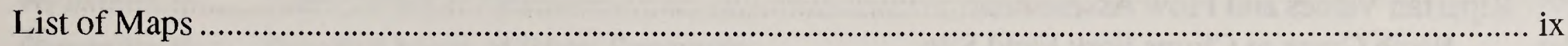

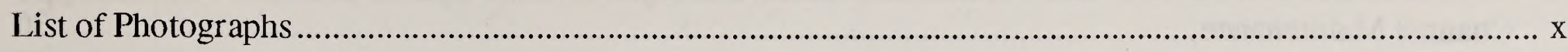

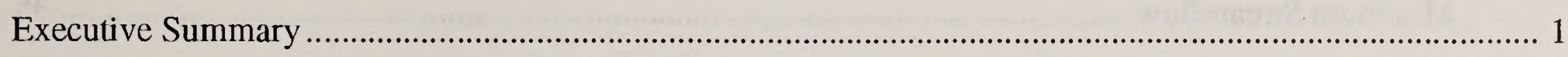

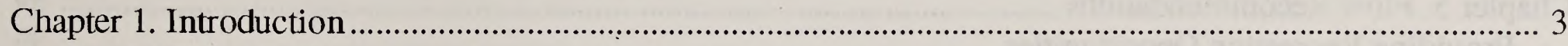

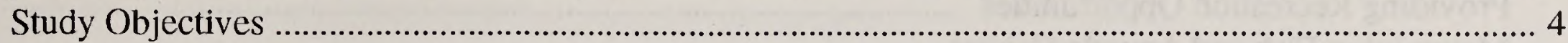

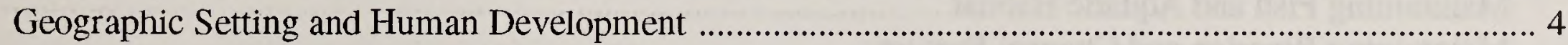

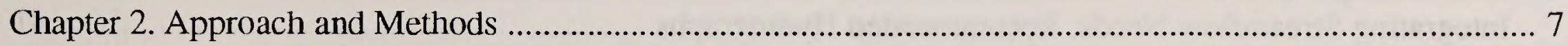

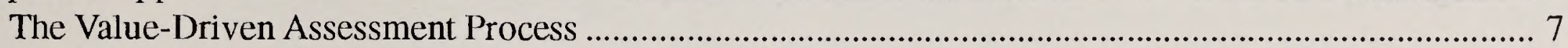

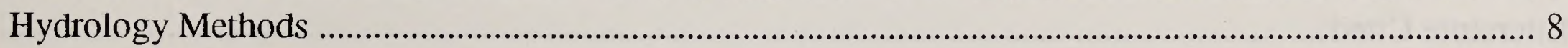

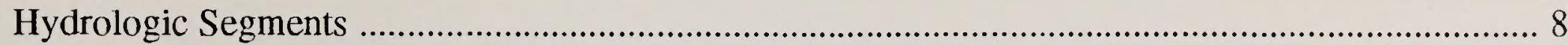

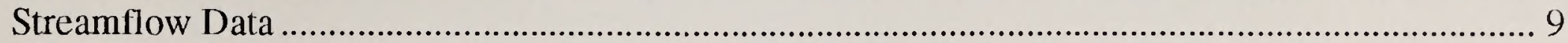

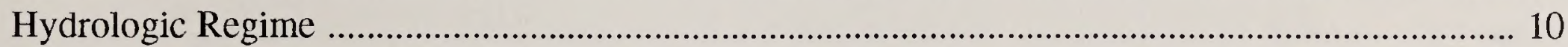

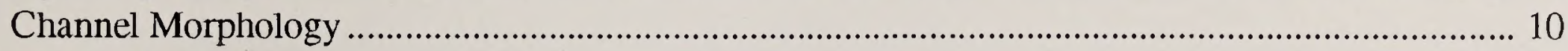

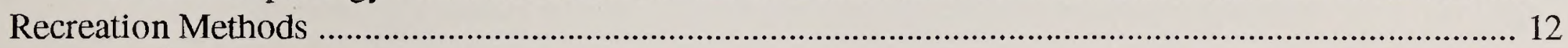

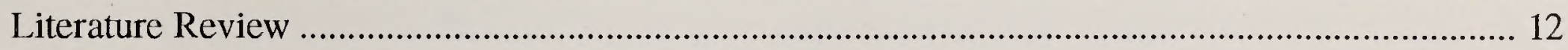

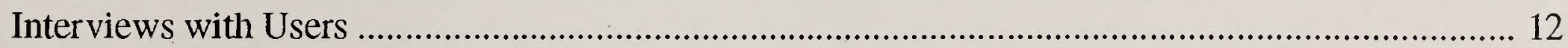

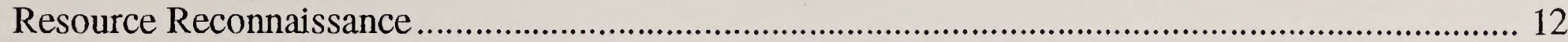

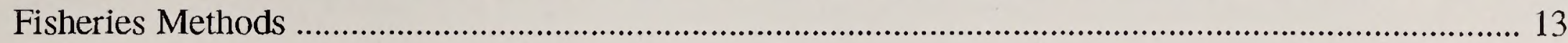

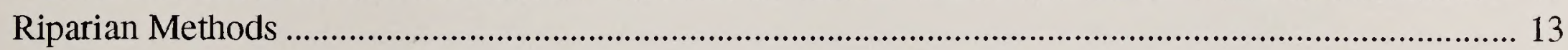

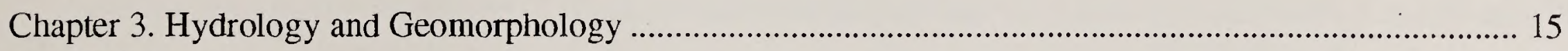

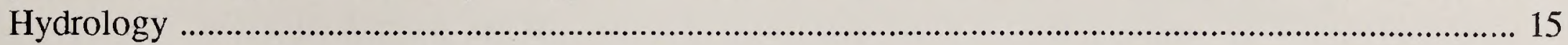

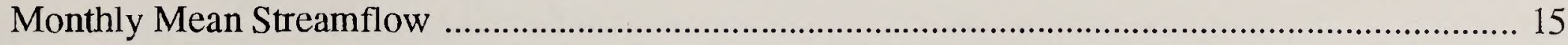

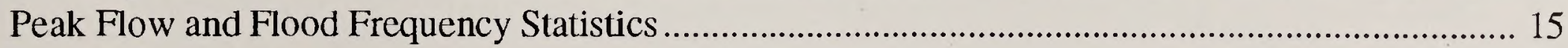

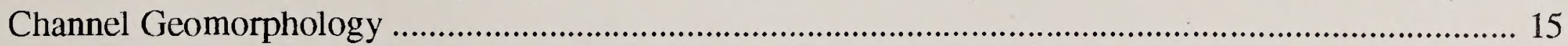

Chapter 4. Resource Values and Flow Needs Analysis ...................................................................... 19

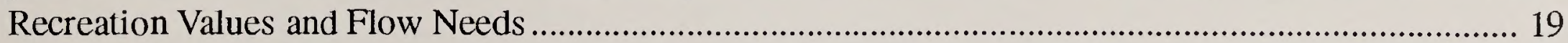

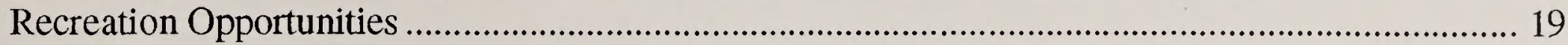

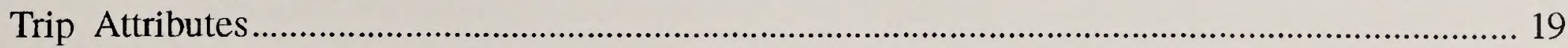

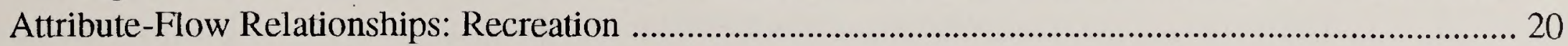

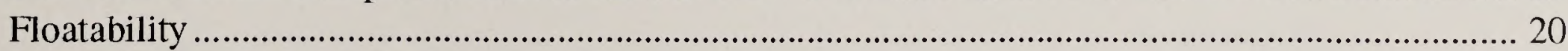

Definitions of Floatability Problems .................................................................................. 22

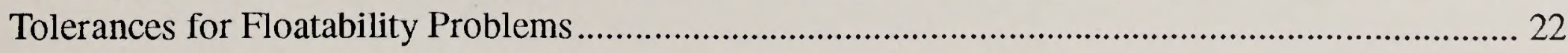

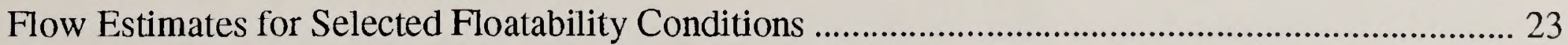

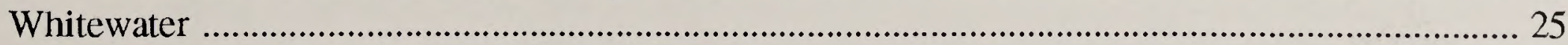

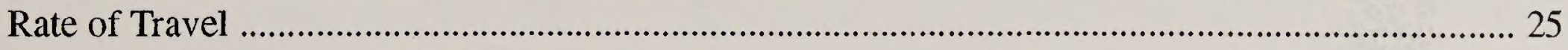

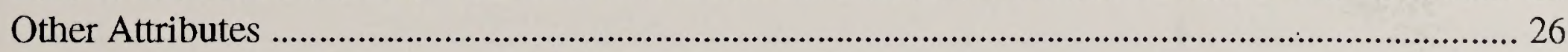

Overall Flow Preference Curves for Recreation ................................................................... 26 


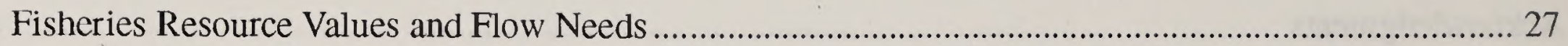

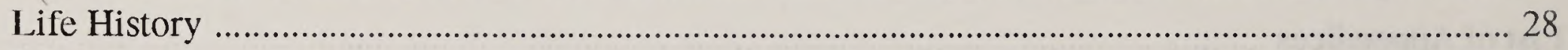

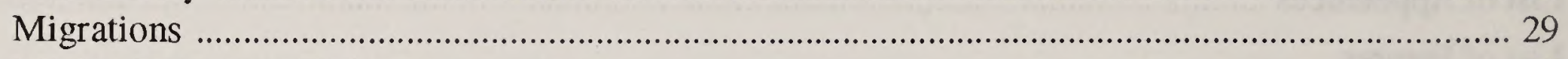

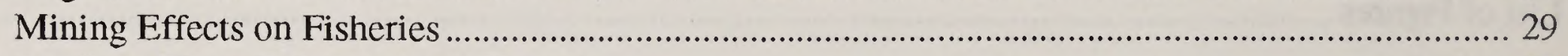

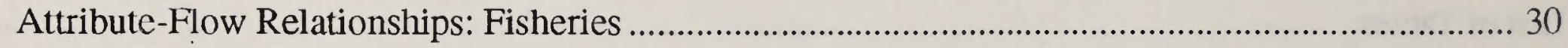

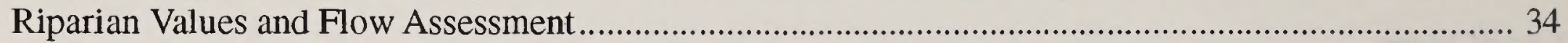

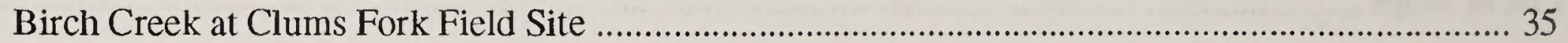

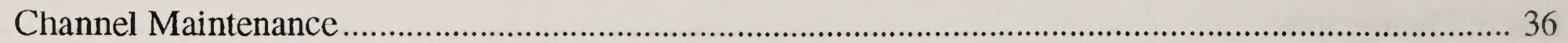

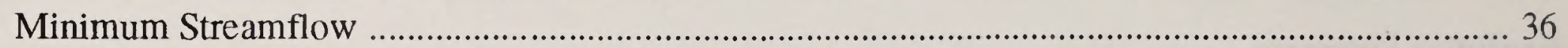

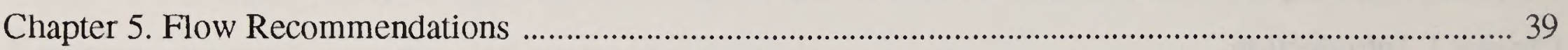

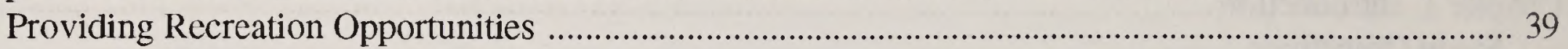

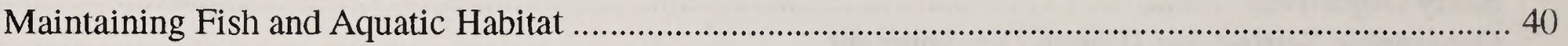

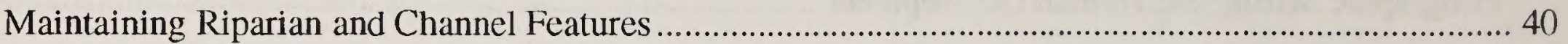

Integrating Streamflow Needs: Recommended Hydrographs ............................................................ 41

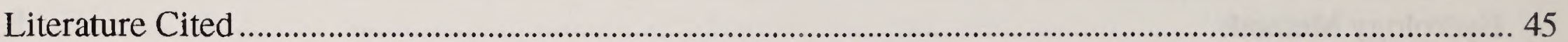




\section{LIST OF APPENDICES}

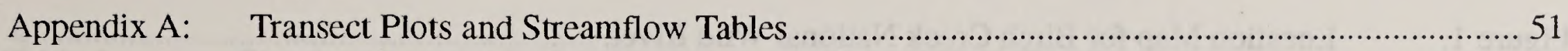

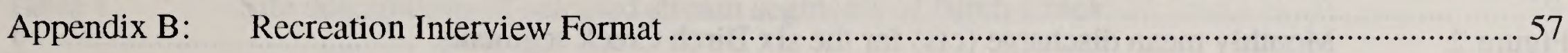

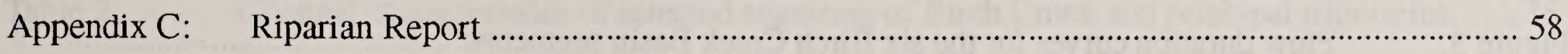

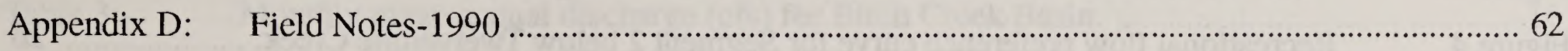

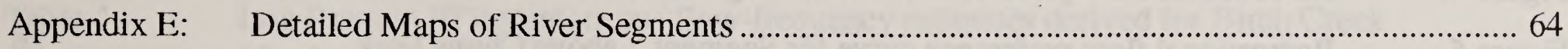




\section{List of Figures}

Figure 1. Location Map for Birch Creek National Wild River. 5

Figure 2. Monthly mean discharge (cfs) for the six Birch Creek segments. 16

Figure 3. Flow duration curves for the six Birch Creek Basin segments. 17

Figure 4. Recreational flow preference curve for Segment 2 below Twelvemile Creek. 26

Figure 5. Recreational flow preference curve for Segment 3 above Clums Fork. 26

Figure 6. Recreational flow preference curve for Segment 4 above Harrison Creek. 27

Figure 7. Recreational flow preference curve for Segment 5 below South Fork. 27

Figure 8. Recreational flow preference curve for Segment 6 at Steese Highway Bridge. 27

Figure 9. Wetted perimeter vs. discharge plot for Birch Creek above Twelvemile Creek. 31

Figure 10. Wetted perimeter vs. discharge plot for Birch Creek below Twelvemile Creek. 31

Figure 11. Wetted perimeter vs. discharge plot for Birch Creek above Clums Fork. 32

Figure 12. Wetted perimeter vs. discharge plot for Birch Creek above Harrison Creek. 32

Figure 13. Wetted perimeter vs. discharge plot for Birch Creek below South Fork. 33

Figure 14. Wetted perimeter vs. discharge plot for Birch Creek at Steese Highway Bridge. 33

Figure 15. Cross-section of channel and floodplain at Birch Creek above Clums Fork showing vegetation zonation......

Figure 16. Monthly mean and recommended streamflow for Birch Creek above Twelvemile Creek (Segment 1).

Figure 17. Monthly mean and recommended streamflow for Birch Creek below Twelvemile Creek (Segment 2). 42

Figure 18. Monthly mean and recommended streamflow for Birch Creek above Clums Fork (Segment 3).

Figure 19. Monthly mean and recommended streamflow for Birch Creek below Harrison Creek (Segment 4).

Figure 20. Monthly mean and recommended streamflow for Birch Creek below South Fork (Segment 5). 44

Figure 21. Monthly mean and recommended streamflow for Birch Creek at Steese Highway Bridge (Segment 6). 44

Figure 22. Channel cross-section for Birch Creek above Twelvemile Creek. 51

Figure 23. Channel cross-section for Birch Creek below Twelvemile Creek. 52

Figure 24. Channel cross-section for Birch Creek above Clums Fork. ......................................... 53

Figure 25. Channel cross-section for Birch Creek above Harrison Creek........................................ 54

Figure 26. Channel cross-section for Birch Creek below South Fork. .............................................. 55

Figure 27. Channel cross-section for Birch Creek at Steese Highway Bridge. ................................. 56 


\section{LisT OF TABLES}

Table 1. Site descriptions of selected stream segments of Birch Creek. ..................................... 9

Table 2. Channel characteristics of selected segments of Birch Creek and principal tributaries....... 15

Table 3. Monthly mean annual discharge (cfs) for Birch Creek Basin. ...................................... 16

Table 4. Log Pearson III instantaneous flow-frequency estimates derived for Birch Creek (discharge in cfs).

Table 5. Bankfull discharge calculated by four different methods and averaged for Birch Creek

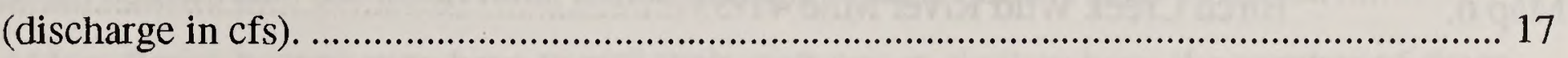

Table 6. Channel geometry at low and high discharge at two sites on Birch Creek. ...................... 18

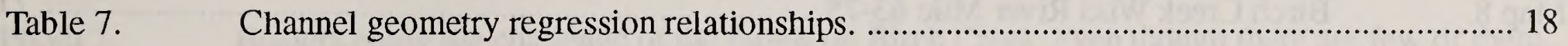

Table 8. Effects on channel geometry with 50\% flow reduction.............................................. 18

Table 9. Flow-related trip attributes of Birch Creek float trips. ................................................ 21

Table 10. User tolerances for floatability problems for Birch Creek per day................................. 23

Table 11. Threshold flow estimates for selected floatability conditions for Birch Creek

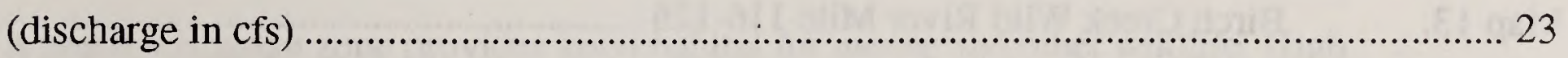

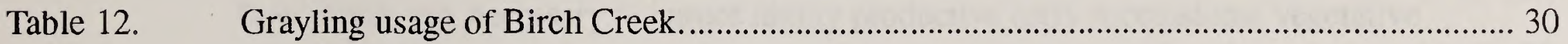

Table 13. Optimum habitat parameters for various grayling life stages ....................................... 34

Table 14. Minimum instream flows for fisheries using different criteria (discharge in cfs).............. 34

Table 15. Minimum instream flows for fisheries based on seasonal flow variations

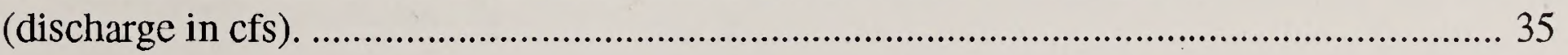

Table 16. Riparian channel and floodplain maintenance flows for Birch Creek (discharge in cfs).... 37

Table 17. Summary of important resource values and recommended flow needs for Birch Creek (discharge in cfs).

Table 18. Recommended streamflows by month for the six segments for Birch Creek

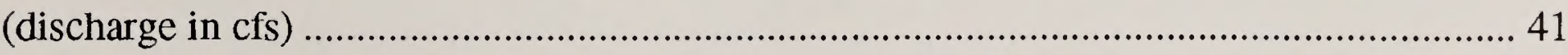

Table 19. Rating table for Birch Creek above Twelvemile Creek. .............................................. 51

Table 20. $\quad$ Rating table for Birch Creek below Twelvemile Creek. .............................................. 52

Table 21. Rating table for Birch Creek above Clums Fork. ................................................... 53

Table 22. Rating table for Birch Creek above Harrison Creek. .................................................. 54

Table 23. Rating table for Birch Creek below South Fork. .................................................... 55

Table 24. Rating table for Birch Creek at Steese Highway Bridge. ............................................ 56 


\section{LiST OF MAPS}

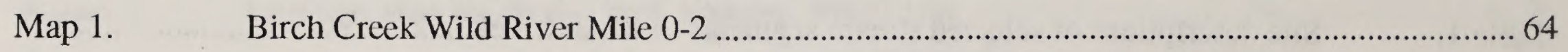

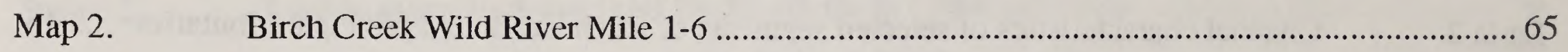

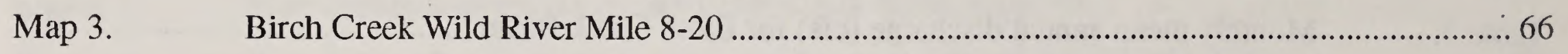

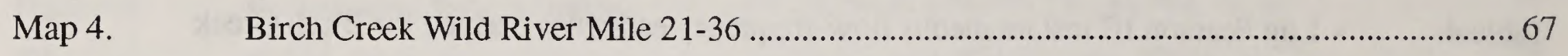

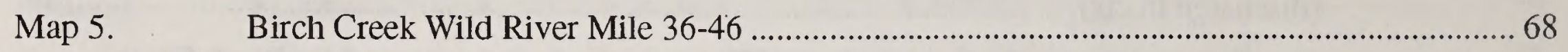

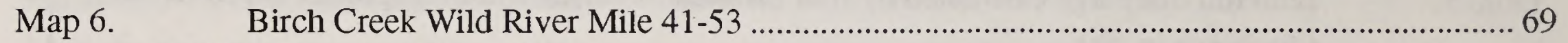

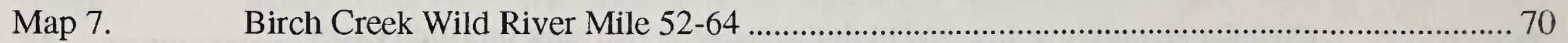

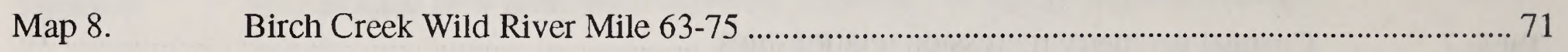

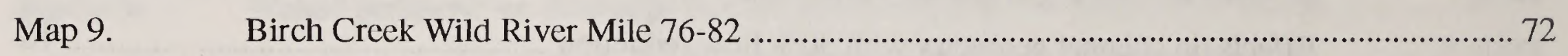

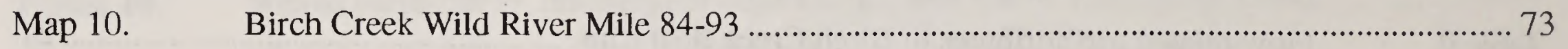

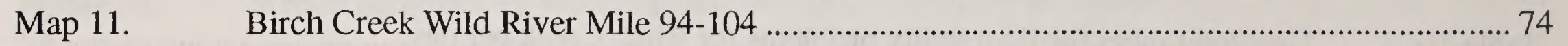

Map 12. Birch Creek Wild River Mile 106-116 _........................................................................ 75

Map 13. Birch Creek Wild River Mile 116-126 ..................................................................... 76 


\section{List of Photographs}

Photo 1. Birch Creek National Wild River offers opportunities for exploring Interior Alaska

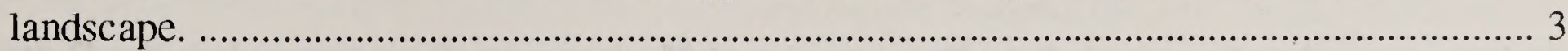

Photo 2. The BLM approach features an interdisciplinary team and integrated field work. ............... 7

Photo 3. Existing hydrology data was augmented with cross-section surveys and computer models. . 8

Photo 4. Under-ice streamflow measurements were made to supplement scarce winter flow data. ..... 9

Photo 5. Some boaters also use small rafts, although these result in slower rates of travel. ............. 19

Photo 6. At low flows, boaters may have to pull their craft across shallow bars; the number of drags

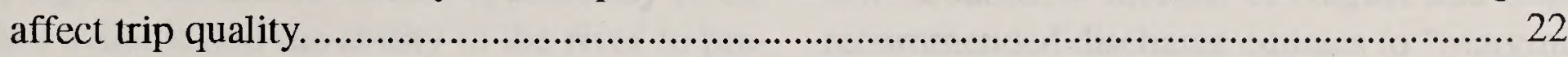

Photo 7. Boaters enjoy the challenge of the rapids on Birch Creek, even though there are few of them. Higher flows provide a greater challenge.

Photo 8. High quality recreation experiences depend in part on the existence of expansive gravel bars, which are maintained by periodic high flows.

Photo 9. Grayling are found throughout the river; different life stages have different flow requirements.

Photo 10. A healthy riparian zone provides good habitat for moose and other wildlife. High flow events are necessary to ensure highly productive early successional vegetative communities. 



\section{EXeCUTIVe Summary}

Birch Creek, a clear-water tributary to the Yukon River, in eastern interior Alaska, was designated a National Wild River by Congress on December 2, 1980. Inclusion into the Wild and Scenic Rivers System was based on primitiveness, road accessibility at an upstream and downstream point, outstanding geologic features, peregrine falcon nesting habitat, archeological and scenic values, opportunity to experience solitude and the ability of the river to provide outstanding recreational opportunities.

In 1989, BLM began an instream flow water resources monitoring project on Birch Creek. The goal of this project was to identify the amount of water (discharge or streamflow) necessary to preserve and protect the natural values of the Birch Creek Wild River and its immediate corridor environs and to recommend a legal mechanism through which those recommended streamflow regimes can be recognized and protected. While optimum streamflow regimes were identified, lesser values may be recommended when the optimum exceeds the natural streamflow regime.

River resource values are nearly all dependent to some degree on stream discharge. Results of literature reviews and field surveys were used to establish relationships between resource values and discharge.

Three types of recreational streamflow conditions for boating were identified on Birch Creek:

- Higher streamflow "optimum floatability and whitewater" conditions.

- Medium streamflow "optimum floatability" conditions.

- Lower streamflow "marginal floatability" conditions.

While many recreation users might prefer optimum floatability and whitewater throughout the summer, most recognize that the natural streamflow regime does not always provide optimum recreational opportunities. Accordingly, the recommended streamflow for recreation is tempered by actual streamflow expected under the natural regime. Streamflow in the middle of the optimum range is recommended during the typical high streamflow month (May), while streamflow on the low end of the "optimum floatability" range is recommended as the discharge decreases through June and July. In the low streamflow months of August and September, recommended discharge equates to "marginal floatability" conditions because higher discharges are uncommon at that time.

Protection of the grayling and other fisheries requires discharges sufficient to provide certain depths and wetted perimeters for various life stages during different times of the year. The critical life stages and time periods are listed below:

- Winter habitat for survival from December through March.

- Migration streamflow in April and from October to November.

- Early summer habitat in May and June.

- Normal summer habitat in July and August.

In the early summer, streamflow is required to provide good spawning habitat as well as to clean the gravel beds for spawning and macro-invertebrate production throughout the year. This streamflow is estimated to be at least 25 percent of bankfull discharge. During the main part of summer, streamflow is required for basic survival and fry rearing. Recommended streamflow is well below the monthly mean discharge. During the winter months, almost all of the available streamflow ( 90 percent of monthly average discharge) is necessary to maintain riffle depths and velocities for grayling survival and passage. In April and then again in October and November, streamflow is needed to allow migration to and from winter habitat. These streamflow recommendations are almost equal to expected natural streamflow ( 90 percent of monthly averages). 
Streamflow is needed to maintain channel form and function for aquatic and terrestrial habitat as well as for high quality recreation. Streamflow maintains the natural integrity of the river channel and its features. Two quantities of streamflow were identified:

- Channel maintenance streamflow equal to the bankfull level for at least a day annually.

- Minimum summer streamflow to maintain riparian vegetation survival during low streamflow times.

A summary of monthly instream streamflow requirements for the six surveyed segments is presented in Chapter 5 under the subsection, Integrating Streamflow Needs: Recommended Hydrographs.
Recommended streamflow for any given time period is that which satisfies the streamflow requirements of all resource values for each river segment.

The project team recommends that a State of Alaska Application for Reservation of Water be submitted to the Alaska Department of Natural Resources, Division of Mining and Water Management, Water Resources Section, specifying the streamflow amounts recommended in this report.

The project team also recommends that BLM quantify the instream values and file an Application for Reservation of Water with the Alaska Division of Natural Resources to protect the tributaries to Birch Creek with the most significant fisheries values. These include: Twelvemile Creek, Harrington Fork, Clums Fork, Harrison Creek and the South Fork. 


\section{ChAPTER 1. InTRODUCTION}

Birch Creek is a clear-water tributary of the Yukon River in the eastern interior of Alaska and features important recreational, wildlife, and scenic values. The Alaska National Interest Lands Conservation Act of December 2, 1980, (ANILCA, P.L. 96-487) established the upper portion of Birch Creek as a component of the National Wild and Scenic Rivers System. Approximately 126 miles of Birch Creek were classified as "wild" pursuant to the Wild and Scenic Rivers Act (USDI 1983). Inclusion into the Wild and Scenic Rivers System was based on primitiveness, road accessibility at an upstream and downstream point, outstanding geologic features, peregrine falcon nesting habitat, archeological and scenic values, opportunity to experience solitude and the ability of the river to provide outstanding recreational opportunities (USDI 1973 and USDI 1973a).

National Wild River status, however, does not necessarily ensure protection of instream river flows, nor guarantee a specific flow regime. The river management plan for Birch Creek specified that the Bureau of Land Management (BLM) conduct a water rights assessment and quantification to establish "a reservation of minimum water flows sufficient for public recreation use and to support the values for which the wild river was designated" (USDI 1983). The plan also noted that this reservation "will be determined in cooperation with the Alaska Department of Natural Resources Division of Land and Water Management," suggesting that the effort be used in support

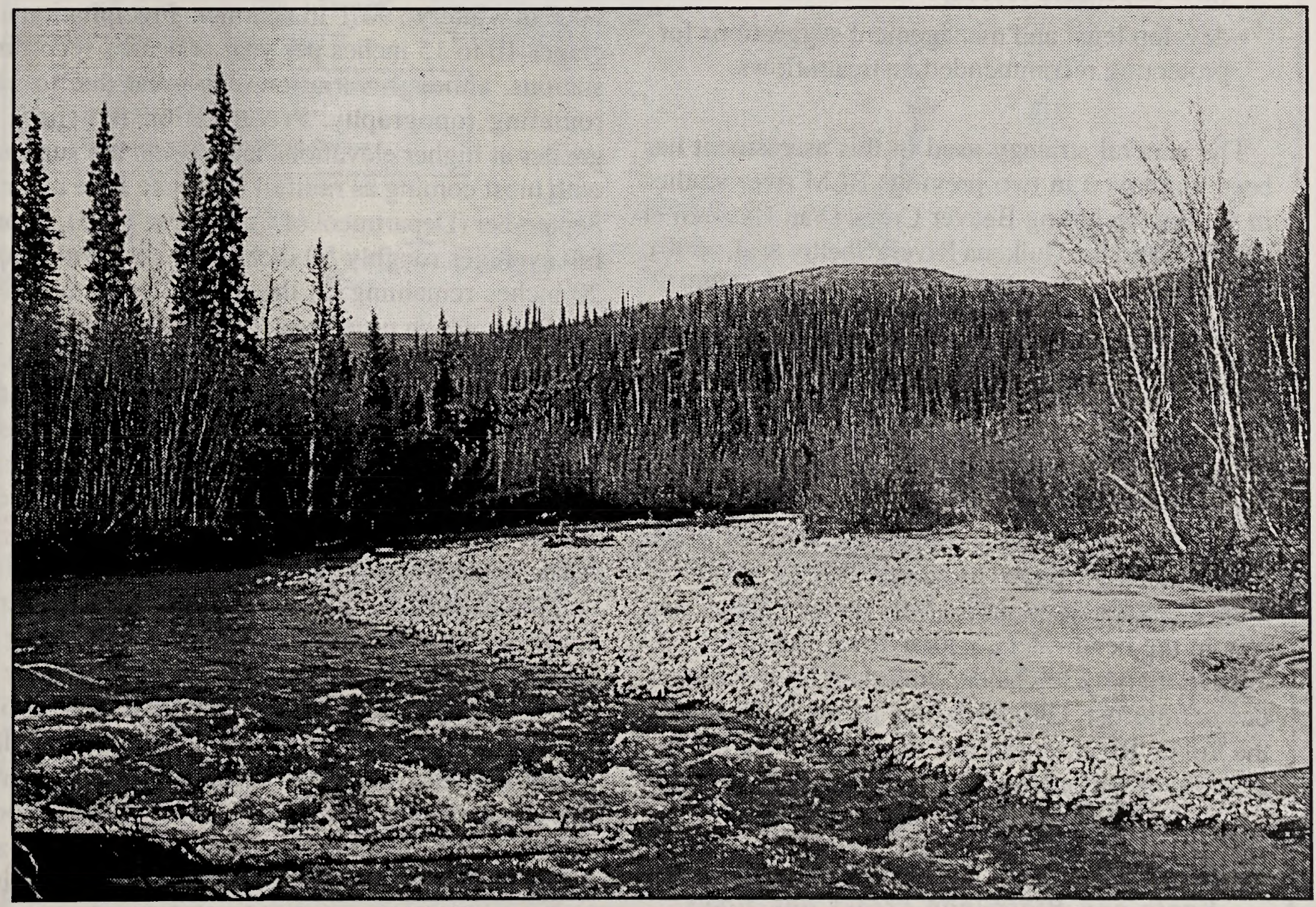

Photo 1. Birch Creek National Wild River offers opportunities for exploring the Interior Alaska landscape. 
of a state water right application. This directive provided the impetus for a water-right assessment for the Birch Creek National Wild River; the outcome of that assessment is provided in this report.

\section{Study Objectives}

The legal and management strategies for protecting Birch Creek streamflow presented in this report stem from an assessment of water rights protection options for the Beaver Creek National Wild River (Van Haveren et al. 1987). The reader is referred to that report for additional information on this subject.

The objectives of this water right assessment are to:

- identify streamflow-dependent resource values,

- determine the natural streamflow regime (average monthly discharge and flood frequencies) of Birch Creek at selected points along the designated National Wild River segment,

- determine what flows are needed to maintain flow-dependent resource values, and

- develop legal and management suggestions for protecting recommended instream flows.

The general strategy used in this assessment has been employed in two previous BLM river studies in Alaska, including Beaver Creek (Van Haveren et al. 1987) and the Gulkana River (Shelby et al. 1990), and is formally described in Jackson et al. (1989).

\section{Geographic Setting and Human Development}

The Birch Creek watershed is part of the YukonTanana physiographic province. This area is characterized by forested upland plateaus, some of gentle relief but others topped by steep 4,000- to 5,000-foot tundra-covered mountains. Intervening valleys, narrow in the headwaters, widen down valley into extensive marshy lowlands, underlain by discontinuous permafrost. Ultimately, the region is drained by the Yukon River. A succinct summary of the basin is given by Ellsworth and Davenport (USDI 1915):

Birch Creek is formed by the junction of Eagle and Ptarmigan creeks and flows southwestward for about 7 miles to the mouth of Twelvemile Creek, where it turns abruptly to the south and follows that direction for about 8 miles. It then receives the waters of Harrington Fork and takes an easterly course for about 45 miles to its confluence with the South Fork. The river then makes a sharp turn north and about 12 miles farther on leaves the mountainous country and enters the lowlands of the Yukon, through which it meanders sluggishly for over 100 miles, roughly paralleling the Yukon. Birch Creek flows into the Yukon River . . . about 25 miles directly west of Fort Yukon.

This report will cover the 126 miles of Birch Creek included in the National Wild and Scenic River System (see Figure 1), beginning approximately one mile upstream of the confluence with Twelvemile Creek, wild river mile (WRM) 0, and ending at the Steese Highway Bridge (WRM 126).

The basin lies in the subpolar continental climatic zone that features long cold winters and short hot summers. Temperature extremes range from minus $70^{\circ} \mathrm{F}$ in winter to $90^{\circ} \mathrm{F}$ in summer. Precipitation averages 10 to 15 inches per year at nearby recording stations, although variations are great due to surrounding topography. Precipitation is generally greater at higher elevations and during the summer, with most coming as rainfall from late June to early September (Department of Commerce 1963). Snowfall averages roughly 50 inches per year with about 20 inches remaining on the ground prior to spring break-up, which usually occurs in late April to midMay. Freeze-up often begins at higher elevations in mid-September, although some streams lower in the basin remain open until November. Ice cover is usually continuous over the winter, except in the vicinity of springs, and freezing to the bottom may occur (Webb 1982-86).

The uplands are underlain by Precambrian to Tertiary meta-sedimentary rocks, typified by the Birch Creek schist. The taller mountains, consisting of younger intruded granitic rocks, show evidence of localized Pleistocene glaciation (Pewe et al. 1967). The dendritic drainage pattern of the area is controlled by the northeastward trend of the bedrock structures. The lowlands are underlain by unconsolidated floodplain deposits, river terraces, alluvial fans, dunes, and lake deposits. Much of this material was deposited during the Pleistocene, when local alpine glaciers provided higher streamflow with greater erosional and depositional processes. This resulted in localized 
areas of mineral deposition (placer deposits), principally gold, throughout the basin (Mertie 1937).

Birch Creek basin is largely undeveloped with the exception of placer mining. The upstream portions of Birch Creek, Harrison Creek, Crooked Creek, and numerous smaller tributaries have all been extensively mined, and some of those claims remain active today. The mining usually consists of stripping and stockpiling the vegetative mat and organic soils, re-channeling the stream into artificial bypasses, and mining the valley to bedrock. Reclamation after mining ceases may include leveling disturbed ground, constructing new channels or reinforcing the bypass, and respreading stockpiled overburden.

While not specifically addressed in this study, mining activity in the river basin has some consequences for instream flow issues. Most of the mined areas are upstream of the Wild River Corridor and are managed by the BLM. They can affect downstream drainage through increased sedimentation, decreased channel stability, and higher flooding due to decreased channel and floodplain storage (Madison 1981). The increased sedimentation of fine material on the bed of mine-affected streams may also reduce the hydraulic conductivity between surface and subsurface water (Bjerklie and LaParriere 1985). While high discharge events (flushing flows) normally serve to cleanse the stream bed and maintain channel morphology, increased sediment loading often exceeds the capacity of the stream to naturally prevent clogging of the substrate (Weagle 1980). Maintenance of sufficient streamflow to ensure adequate aquatic habitat becomes even more significant because of these effects on the basin. These complicating factors were considered in the analysis of flow needs for aquatic habitat for fish and channel maintenance. Additional background information can be found in the BLM's placer mining EIS for Birch Creek (USDI 1988).

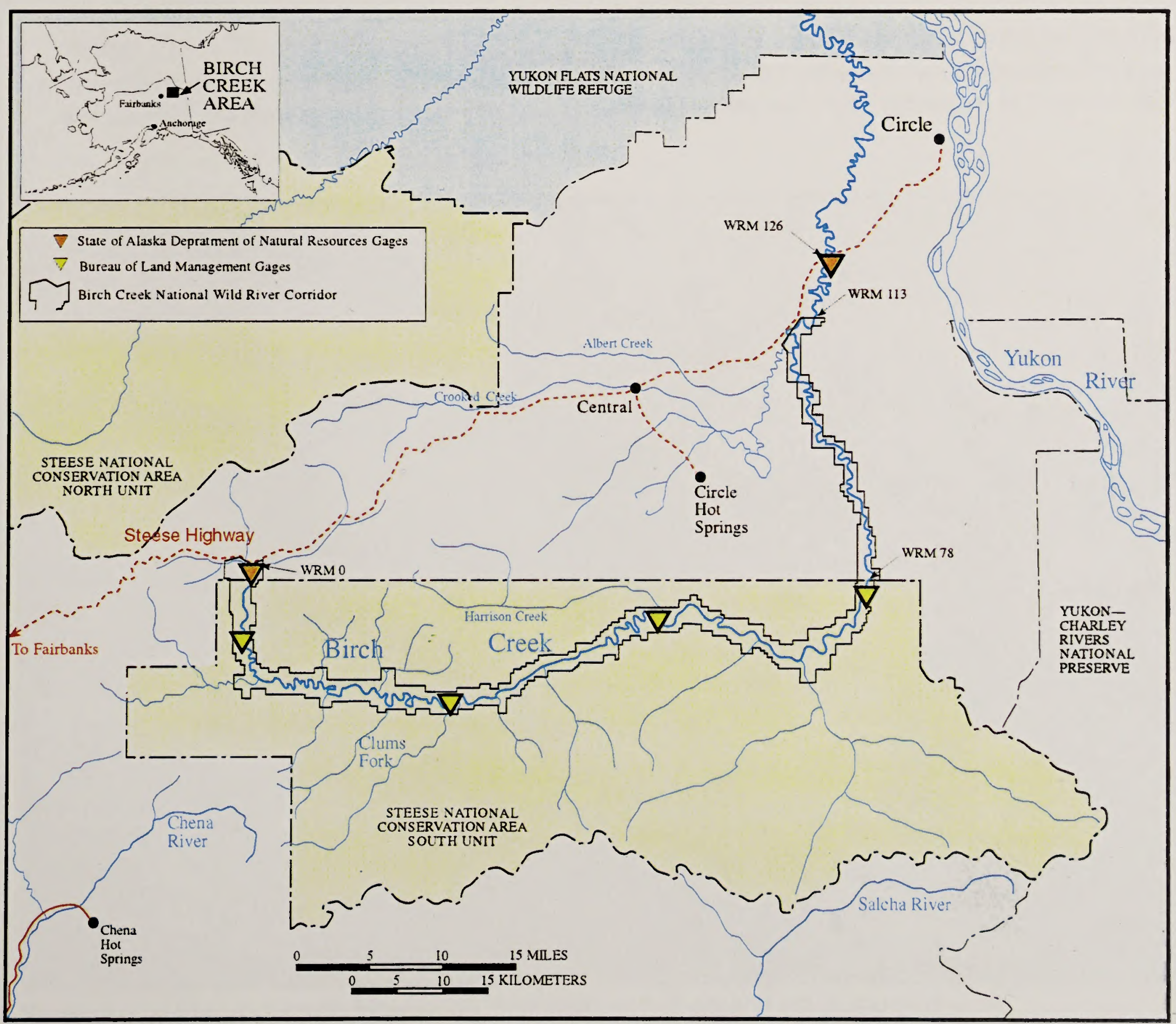

Figure 1. Location Map for Birch Creek National Wild River. 



\section{Chapter 2. APPROACH AND Methods}

\section{The Value-Driven Assessment Process}

The approach of this study utilizes an interdisciplinary team to conduct literature reviews and reconnaissance-level field studies as a basis for developing relationships between flows and water-dependent resource values. Jackson et al. $(1987,1989)$ have described this interdisciplinary approach as consisting of six general steps:

- Preliminary assessment and project design,

- Description of streamflow-dependent resource values,

- Quantification and description of hydrology and channel morphology,
- Analysis of the effects of streamflow on resource values,

- Identification of streamflow required to protect resource values, and

- Development of the legal strategies to protect instream flows.

The specific methods required to complete these steps for Birch Creek included literature reviews, resource reconnaissance, hydrological and other resource data collection and modeling, and professional judgment and analysis.

A central focus of the effort was the on-site field work. Resource reconnaissance specifically organized for this study was conducted in June and July

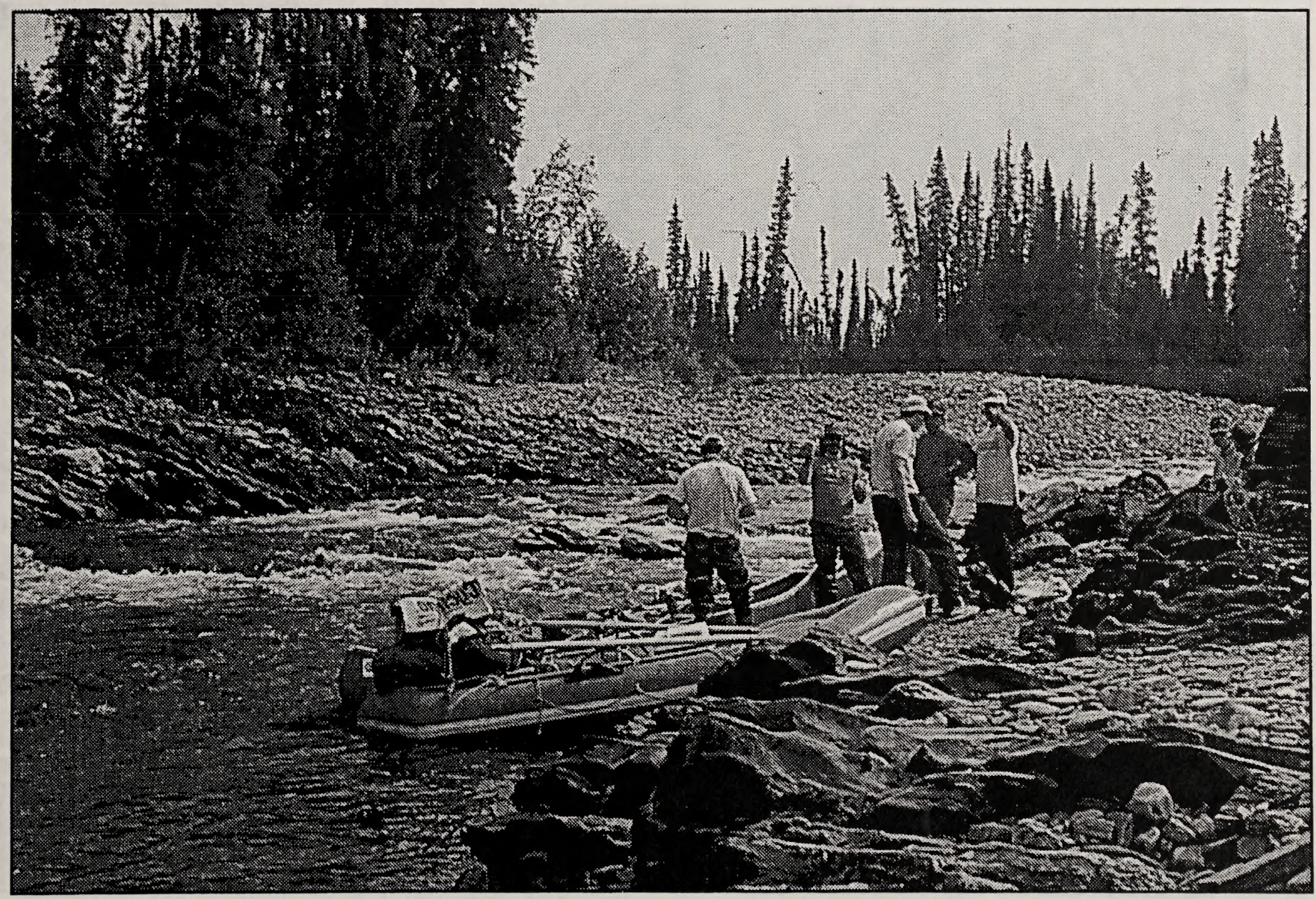

Photo 2. The BLM approach features an interdisciplinary team and integrated field work. 
of 1990, and consisted of two separate trips on the river. Trips were taken in rafts and canoes to assess floatability differences. The first trip was taken at medium water levels. The second was taken at extremely low water levels. Supplemental field work was conducted in subsequent years by BLM hydrology staff to collect better streamflow information, including two winter trips per year to conduct under-ice flow measurements. A discussion of the specific methods used by team members is given below.

\section{Hydrology Methods}

The goal of the hydrologic assessment was to determine monthly mean discharge for six hydrologic segments, as well as to identify flood frequency and instantaneous peak streamflow. Hydraulic geometry data were also collected at selected locations to represent characteristic reaches and help other resource specialists explore relationships between streamflow and resource values at those sites. Selection of criti- cal reaches was based on the identification of both wild river values and measurable criteria to quantitatively express them. Table 1 lists representative reaches within each study section and the survey sites chosen within each reach. These sites were sampled by the team from July $20-26,1990$. Hydraulic geometry cross sections were measured at representative locations in the critical reaches. Team members chose representative locations that corresponded to identified resource values. River discharge measurements were taken at nearby points hydraulically suitable for stream gaging. Significant tributaries, while surveyed to determine their hydrologic properties, were not analyzed for streamflow requirements.

\section{Hydrologic Segments}

Birch Creek streamflow varies substantially along its length due to basin topography and tributary inputs. Accordingly, the river was divided into six hydrologic segments with distinct flow characteristics. Hydrologic data was collected relative to these six



Photo 3. Existing hydrology data was augmented with cross-section surveys and computer models. 
segments and gage stations. The six segments and the corresponding gage station locations are summarized below and listed in Table 1:

- WRM 0 to Twelvemile Creek (above Twelvemile Creek)

- Twelvemile Creek to Harrington Fork (below Twelvemile Creek)

- Harrington Fork to Clums Fork (above Clums Fork)

- Clums Fork to South Fork (above Harrison Creek)

- South Fork to WRM 78 (below South Fork)

- WRM 78 to Steese Bridge (Steese Highway Bridge)

\section{Streamflow Data}

The United States Geological Survey (USGS) did extensive stream gaging in the Birch Creek basin during the initial gold rush, a period from about 1908 to 1912 (USDI 1915). Prior to 1990 , the only recent streamflow data are published by the Alaska Department of Natural Resources, Division of Mining and Water Management (DNR). These consist of stream gages on Birch Creek above Twelvemile Creek and at the Steese Highway Bridge, operated seasonally from 1985 to the present (Ray 1990, 1991, 1992, 1993; Vohden 1994). Additionally, stream gaging sites were initiated by BLM at three locations on Birch Creek in the fall of 1989 and data collected to the present (Kostohrys \& Sterin 1996). All estimates of winter discharge were based on the BLM streamflow measurements at these sites. All of the hydrology data from the BLM and DNR gages from 1989 to 1994 are in the reports noted above. Crosssectional survey data and streamflow tables are included in Appendix A.

At each field site, gages were surveyed to reference elevation (bench) marks, significant high-water marks and the current water level (Benson and Dalrymple 1967). Cross-sectional discharge (streamflow) measurements were made using a Price AA current meter to measure water velocity and a top-setting wading rod and tag line for depth and width (Rantz et al. 1982). Winter measurements were made by drilling a series of holes in the ice to define the cross-section and measuring

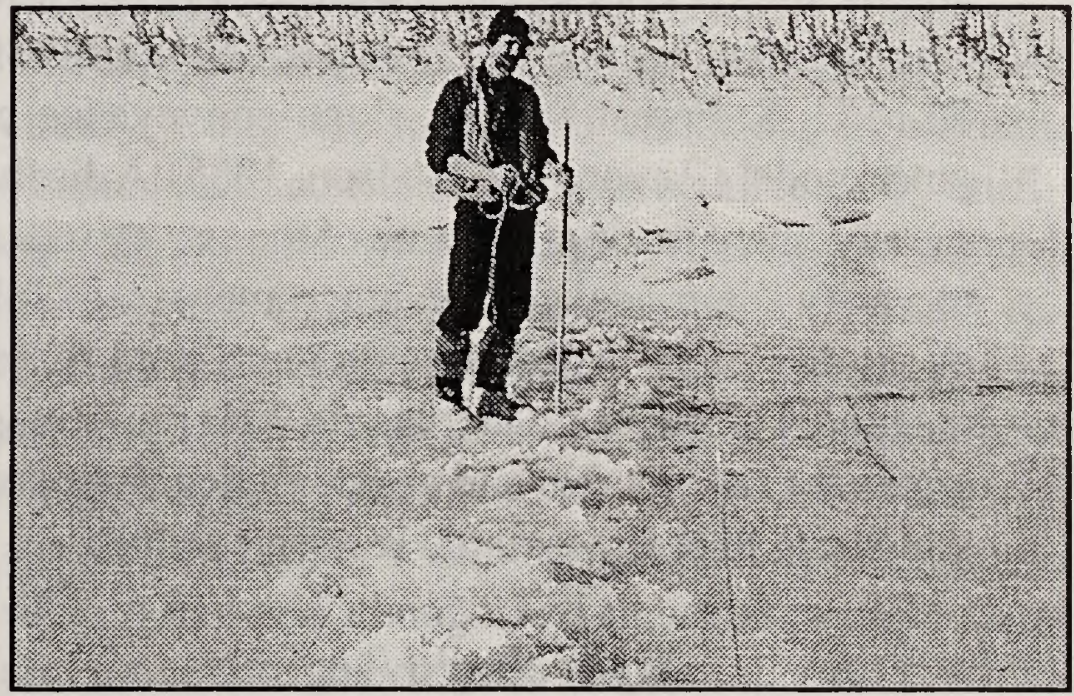

Photo 4. Under-ice streamflow measurements were made to supplement scarce winter flow data.

Table 1. Site descriptions of selected stream segments of Birch Creek.

\begin{tabular}{|c|c|c|c|c|c|}
\hline Stream Segment & $\begin{array}{l}\text { : legal : } \\
\text { Description }\end{array}$ & $\begin{array}{l}\text { Channel } \\
\text { Type }\end{array}$ & $\begin{array}{l}\text { Stream } \\
\text { Banks }\end{array}$ & $\begin{array}{l}\text { Bottom } \\
\text { Material }\end{array}$ & $\begin{array}{l}\text { Pools } 8 \\
\text { Rifles }\end{array}$ \\
\hline 1. Birch Creek above Twelvemile $\mathrm{Ck}$ & $\begin{array}{l}\text { SW 1/4, Sec. } 33 \text {, } \\
\text { T.6 N., R. } 10 \text { E., FM. }\end{array}$ & Meandering & Alluvium & Cobbles/gravel & $\begin{array}{c}\text { Shallow pools } \\
\text { Riffles numerous }\end{array}$ \\
\hline 2. Birch Creek below Twelvemile $\mathrm{Ck}$ & $\begin{array}{l}\text { SW 1/4, Sec. } 20, \\
\text { T.6N., R. } 10 \text { E. FM. } \\
\end{array}$ & Meandering-Braided & Alluvium & Cobbles/gravel & $\begin{array}{l}\text { Shallow pools } \\
\text { Riffles numerous }\end{array}$ \\
\hline 3. Birch Creek above Clums Fork & $\begin{array}{l}\text { NW 1/4, Sec. 14, } \\
\text { T.5 N., R. } 12 \text { E., FM. }\end{array}$ & Meandering-Braided & Alluvium & Sand/Gravel & $\begin{array}{c}\text { Deep pools } \\
\text { Riffles infrequent }\end{array}$ \\
\hline 4. Birch Creek above Harrison CK & $\begin{array}{l}\text { SW } 114, \text { Sec. } 13 \\
\text { T.6N., R. } 14 \text { E. FM. }\end{array}$ & Meandering-Incised & Bedrock & Cobbles/boulders & $\begin{array}{l}\text { Shallow pools } \\
\text { Riffles numerous }\end{array}$ \\
\hline 5. Birch Creek below South Fork & $\begin{array}{l}\text { SE 1/4, Sec. } 8, \\
\text { T.6 N., R. } 17 \text { E., FM. }\end{array}$ & Meandering-Incised & Bedrock & Cobbles/boulders & $\begin{array}{c}\text { Deep pools } \\
\text { Riffles numerous }\end{array}$ \\
\hline 6. Birch Creek at Steese Hwy Bridge & $\begin{array}{l}\text { NE } 1 / 4, \text { Sec. } 11 \text {, } \\
\text { T.10 N., R. } 16 \text { E., FM }\end{array}$ & Meandering & Alluvium & Sand/silt & $\begin{array}{l}\text { Deep pools } \\
\text { Riffles infrequent }\end{array}$ \\
\hline
\end{tabular}


the depth and velocity in each hole using a verticalaxis, vane-type current meter mounted on a graduated rod (Rantz et al. 1982). At all gaging sites, multiple cross-sections were surveyed to determine peak streamflow using the slope-area method (Dalrymple and Benson 1967). Rating curves, log-log regression plots of water level versus discharge, were then developed from discharge measurements made during 1989 through 1994 (Rantz et al. 1982). These rating curves were then used to compute the rating tables and associated cross-sectional properties.

At other sites, selected in the field during float trips in June and July 1990 to represent resource-related values (floatability, fish passage, etc.), a single crosssection and longitudinal profile was surveyed. Care was taken in selecting sites that were uniform in flow characteristics so as to meet the requirements of the hydraulic model as well as to allow comparability among sites (Leopold and Skibitzke 1967). The data was processed using CROSS, a modification of the BLM/U. S. Forest Service slope-conveyance computer model (Parsons and Hudson, 1985). A discharge measurement made at the time of the survey was used to verify the model for the stage measured. Subsequent discharge measurements were used to verify the model at varying water levels. This program generates the rating table and cross-sectional properties that relate to the associated resource values.

\section{Hydrologic Regime}

The mean monthly flow hydrographs for Birch Creek stations were derived from DNR gaged data (Ray 1990-92; Vohden 1994), BLM winter discharge measurements, data logger, and crest gage data. Computation of mean monthly flow at the sites with crest gages were determined by regression analysis of data logger records from the gage below South Fork, selected as the reference gage. Periods of no data, generally during April and May when water levels are fluctuating due to the effects of ice and snow run-off were estimated from regression comparisons with the Salcha River (USGS 1990-1995).

Streamflow for the winter period was estimated using regression curves derived from under-ice discharge measurements. One set of measurements was made in late fall/early winter and another in late winter/early spring to define the fall recession and winter low flow, respectively. This methodology assumes that once ice and snow cover isolate the stream from precipitation and temperature changes, the flow to the stream recedes uniformly as the water table in the aquifer is lowered by reduction of water volume in the aquifer (Rogers and Armbruster 1990). Accuracy of winter flows is low; as discharge approaches zero, flow measurements become unreliable as the water velocity diminishes below the measuring range of the instrumentation. Variability in the basin can occur as flows diminish downstream from the headwaters due to storage as ice. Streamflow may cease altogether if additional groundwater sources are not available. A flow measurement at one site may have little relationship to other sites in the basin unless geological conditions remain constant. Flow in the lower, unconfined alluvial channels is greater and shows more uniformity than in the upper portions of a basin where bedrock confines the aquifer and groundwater sources are non-continuous (Nelson 1978). Because of these factors, discharges less than about 10 cubic feet per second (cfs) should be considered estimates. Log-linear regressions were done for all sites to estimate the winter period, generally October through March. (Monthly discharge data derived from these various methods is given in the Hydrology and Geomorphology chapter.)

Peak flow statistics for the five stations were computed using a log-Pearson Type III distribution (Benson 1968) and from regional regression equations (Jones and Fahl 1994). The log-Pearson III analysis was completed using Pearson, a small computer statistical package for flood-frequency analysis developed by the BLM Denver Service Center. Peak flow statistics are given in the Hydrology and Geomorphology chapter.

\section{Channel Morphology}

Several channel or floodplain characteristics may provide important resource values, and it was necessary to understand how streamflow-regime changes might affect those characteristics. Team members explored a variety of these relationships through literature reviews and on-site work.

Channel characteristics within a drainage basin or watershed are determined by the climatological and physical characteristics within that basin. A stream develops hydraulic responses to variations in runoff, topography and lithology. Channel gradient, geom- 
etry and sinuosity are the most obvious results of these responses (Morisawa 1968). Channel morphology changes are based on the magnitude of energy input: variations in discharge can alter the bed form, bed material size, channel width, depth and sinuosity (Heede 1976). Relationships between discharge and channel geometry parameters such as cross-sectional area, wetted perimeter, top width, water depth and velocity are useful in determining critical fisheries habitat, channel passage for fish or recreational boating, and development of gravel bar and stream bank features utilized by the fish, wildlife, or recreational users.

Boundary shear stress is the erosional force exerted by the flow of the stream on the bed. This can be expressed in terms of water depth and stream gradient using the Duboys equation:

$$
T=v \mathrm{DS}
$$

Where: $T=$ boundary shear stress $v=$ specific weight of water $\mathrm{D}=$ depth of water $\mathrm{S}=$ stream gradient

While this relationship is only an approximation over the entire range of streambed material sizes and streamflow regimes, the importance of this relationship is that it shows that the stream increases in erosional power as the depth and stream gradient increases (Morisawa 1968).

Williams (1978), among others, states that the bankfull discharge (that water level at which the streamflow fills the channel to the top of the banks) is critical in determining channel morphology. However, he lists 11 definitions for the bankfull discharge and notes that each definition gave a different discharge and that recurrence intervals for those bankfull discharges varied from one to 10 years.

Emmett (1972) relates bankfull discharge to drainage area, specifically for streams in the Yukon region of Alaska, using the relationship:

$$
Q_{b}=27.1 D^{0.79}
$$

Where: $Q_{b}=$ the bankfull discharge $\mathrm{DA}=$ the drainage area
Others (Hill et al. 1991; Van Haveren et al. 1987) assume the bankfull discharge is approximated by the 1.5- to 2-year recurrence interval flow. These flows can be derived from regional flow formulas (Parks and Madison 1985) or computed from a LogPearson Type III analysis of stream gage data. Where significant differences occur, the regional formula can be adjusted to the gage data-derived values by proportional adjustments for discharge and drainage area.

Where field surveys are complete (both banks are surveyed to the level of the floodplain, and the stream is unconfined by rock walls or terraces), the bankfull water level can be graphically approximated by the slope break of the lower stream bank (Emmett 1972). Using discharge data from the computer-simulated flows, the bankfull discharges were determined on five of the Birch Creek sites. Given the variability of results provided by these methods, final estimates for this report were averaged.

While adjustments in channel morphology constantly occur due to natural variations in climate, channel characteristics can also be affected by artificial adjustments of discharge. Altering the natural flow regime may result in decreased flood peaks, reduced channel size and capacity, and increased vegetative growth in overflow channels or encroachment on gravel bars (Hirsch et al. 1990). Alterations in streamflow and/or sediment regime may affect poolriffle ratios and change bed material particle sizes and gravel bar distribution (Hill et al. 1991). While extensive regulation does not occur at this time in Interior Alaska, future development or water diversions in the upper basin (outside of the Wild River Corridor) could impact the natural hydrologic regime of Birch Creek.

Accordingly, two reaches of Birch Creek were analyzed for potential changes in hydraulic properties under a flow reduction scenario. The two sites (above Twelvemile Creek and at the Steese Highway Bridge) exhibit the widest differences in hydrologic characteristics and thus demonstrate variation in hydrologic responses.

The hydraulic properties of these two sites were analyzed at low and high flow regimes, in this case using the mean August flow as a representation of the summer low flow and the 1.5-year log-Pearson data to indicate an approximation of bankfull flow. The hydraulic properties were derived from the tables of cross-sectional characteristics. From these hydrau- 
lic properties, relationships were determined using regression analysis; a value for depth, velocity, and wetted perimeter was calculated for a given discharge. Due to the sharp break in the wetted perimeter curve, two relationships were derived to best fit the data. These relationships were then used to determine the magnitude of change to the hydraulic properties brought about by alterations in streamflow. In this example, a $50 \%$ flow reduction was used. Results of this analysis are summarized in the Hydrology and Geomorphology chapter.

\section{Recreation Methods}

Recreation methods focused on collecting and organizing information about four general areas:

1) available recreation opportunities,

2) specific values or trip attributes associated with those opportunities,

3) relationships between flows and trip attributes, and

4) the identification of specific threshold flows necessary to maintain high-quality recreation opportunities.

These areas were explored through several specific tasks, including a review of information written about the resource, on-site resource reconnaissance, and interviews with resource users. Relationships between flows and trip attributes and the subsequent flow need recommendations were eventually developed through professional judgments, but these were based on a systematic analysis of available information from all these sources, as well as from considerable experience with similar studies of instream flow needs for recreation.

\section{Literature Review}

The literature review focused on recreation opportunities and trip attributes. The Bureau of Outdoor Recreation Wild and Scenic River Analysis, the Birch Creek Management Plan, and recreation crew trip reports were three key sources, providing information about geographic context, physical features, recreation activities and use patterns, and recreation values.

\section{Interviews with Users}

Interviews were conducted with a half-dozen veteran river runners to identify trip attributes, specify flow-attribute relationships, and suggest overall flow needs. The interview format (see Appendix B) was developed from the approach used by the BLM instream flow team in the Beaver Creek, San Pedro River, Gulkana River, Dolores River and Delta River water right assessment studies (see Literature Cited for references), as well as from an instream flow study conducted on the Colorado River in the Grand Canyon (Bishop et al. 1987).

Interviews focused on three different areas. First, users were asked about user experience and trip characteristics: type of craft used, number of trips on Birch Creek, type of user (river manager, private river boater, etc.). Questions also focused on trip attributes or those qualities that define the "Birch Creek experience." Second, users were asked about their sensitivity to various flow levels when planning or taking trips on Birch Creek. Questions asked users to note if they obtained flow information and how they used it. A series of questions examined flow-attribute relationships and evaluations of flows, asking users to specify various flow levels that provide minimum or optimum navigability, floatability, whitewater, fishing, or rate of travel conditions. Finally, users were also asked to give an overall evaluation of flows.

\section{Resource Reconnaissance}

As noted above, the study team took two trips on the river, one at medium flows and one at extremely low flows. Recreation specialists noted the frequency and location of boat passage problems and compared them to those encountered by users on typical trips. Field work also included conducting transects at key riffles to represent boat passage issues and obtain estimates of the flows needed for good boatability. The on-site work was crucial for identifying how users take trips on the river, noting the importance of channel features such as gravel bars for camping, and estimating whitewater challenge at various flows based on experience with whitewater features on a variety of other rivers. 


\section{Fisheries Methods}

A literature search was conducted to develop information on species occurrence, life history and habitat requirements for fish in the Birch Creek system. Professional biologists knowledgeable about the Birch Creek fisheries were also contacted and interviewed.

The dominant sport fish in the Birch Creek basin, as in most Interior Alaska streams, is the Arctic grayling (Thymallus arcticus) (Krueger 1981; Armstrong 1986). Holmes (1981) showed grayling to be the most popular sport fish among anglers in Interior Alaska. Arctic grayling were selected as the representative species for this analysis because of their ecological and economic importance and because data are available concerning habitat utilization by this species. The mainstem of Birch Creek provides habitat for adult and sub-adult (juvenile) grayling (Webb 1977; Gammon 1990). While Birch Creek provides some spawning and fry habitat, much of this habitat type is provided in tributaries to Birch Creek, such as Harrington Fork, Clums Fork and South Fork (Webb et al. 1985; Kretsinger 1986).

An assessment of the relationship between streamflow and habitat availability for adult and juvenile grayling was conducted using a hydraulic analysis to provide relationships between flows and aspects of habitat components such as depths, velocities, and wetted perimeter. An assessment was also conducted on selected flows to maintain the quality of existing aquatic habitat, often referred to as channel maintenance flows.

For each study reach, a transect was located in typical habitat used by Arctic grayling. While shallow riffles or deep pools are indicators of a unique habitat, glides (those areas of uniform flow that form transitions between the pool and riffle) may provide more reliable information about habitat variability since the hydraulic simulations are more accurate. Glides, with their reduced velocity and turbulence, provide resting and feeding areas adjacent to the higher energy areas of the riffle. Glides also provide pool-like habitat for juveniles, which are often excluded from the deeper pools by adults. Information obtained from each cross-section was processed using the hydraulic analysis model. The output from this model, when compared to specific habitat needs such as suitable depths for spawning and migration, mean velocities preferred for juvenile and adults, or substrate availability as indicated by the wetted perimeter, produces a range of stream discharges that reflect the site-specific requirements for a stage in the fisheries life cycle. An optimum streamflow was then determined to protect the identified aquatic resource.

Habitat requirements for Arctic grayling were obtained from literature issued by Alaska Department of Fish and Game (Krueger 1981), Alaska Cooperative Fisheries Research Unit (Reynolds 1989), and U. S. Fish \& Wildlife Service (Hubert et al. 1985). The relationship of wetted perimeter to streamflow was adapted from Prewitt and Carlson (1977); Van Haveren et al. (1987); and DNR (1986).

\section{Riparian Methods}

Riparian areas are generally defined as a zone of unique vegetation bordering flowing waters, lakes and wetlands. For the purposes of this document, the terrestrial riparian zone is defined as any area in or adjacent to a drainageway, or its floodplain, and is characterized by species different than those of surrounding communities. Riparian vegetation influences the amount of incidental light as well as water quality parameters such as suspended solids and water temperature.

Riparian vegetation along Birch Creek is composed of:

1) forests (coniferous, deciduous and mixed),

2) shrub communities [willows (Salix), alder (Alnus crispa) and dwarf birch (Betula nana and Betula glandulosa)], and

3) herbaceous communities [composed of cottongrass (Eriophorum spp.), other sedges (Carex spp.) and ericaceous shrubs)] (Viereck 1970).

Water right assessment documents produced by the BLM, such as the Rio Chama Instream Flow Assessment (Fogg et al. 1992) and Dolores River Instream Flow Assessment (Vandas et al. 1990), base much of their rational for asserting water rights on the assumption that water quantity is the limiting factor in determining composition of riparian vegetation. For Interior Alaska, the literature does not support this assumption. Instead, it describes Alaska ecosystems 
as heat-limited, not water-limited (Van Cleve et al. 1986). High streamflow periods determine permafrost distribution, and therefore control composition of riparian plant communities. Ensuring adequate flow during the growing season is also important. Adequate flow prevents mortality of seedling herbaceous and woody vegetation within the main channel, and along low banks and gravel bars.

A literature search and professional interviews were done to elucidate ecological processes that determine the composition of riparian vegetation communities in Interior Alaska. Appendix C contains a more indepth discussion of riparian areas in Alaska. A channel cross section above Clums Fork was selected to represent a riparian vegetation structure because the floodplain is relatively wide (greater than one mile) and the meanders of Birch Creek and Clums Fork create a mosaic of wetlands and upland vegetation types. Because substantial amounts of deciduous browse are present, the site can be considered representative of high quality moose wintering areas found along Birch Creek. 


\section{Chapter 3. Hydrology AND GeOMORPhOlOGy}

\section{Hydrology}

Table 2 provides site description and channel characteristics of the six selected stream segments of Birch Creek and the gage site locations. It also contains information about the principal tributaries of the river.

\section{Monthly Mean Streamflow}

Monthly mean streamflows for the six Birch Creek segments are given in Table 3. The annual hydrograph for Birch Creek is characterized by very low flows for the winter period (November through April), a high flow period (May and June) from melting snow and rainfall, and a period of moderate flows (July through October) when rainfall augments the gradually declining water table (Kostohrys and Sterin 1996). Graphs of monthly mean streamflow and flow duration are shown in Figures 2 and 3.

\section{Peak Flow and Flood Frequency Statistics}

Instantaneous flow-frequency estimates derived from Birch Creek data are given in Table 4. These were derived from Log Pearson III analyses. Similar analyses using Parks and Madison (1985) and Jones and Fahl (1994) are presented in Kostohrys \& Sterin (1996). Bankfull discharges calculated by four different methods are given in Table 5 along with an average bankfull discharge based on these results.

\section{Channel Geomorphology}

Tables 6,7 and 8 illustrate the effects of flow reduction on channel geometry at two representative sites along the river: above Twelvemile Creek and at Steese Highway Bridge. Table 6 provides representative discharge, depth and velocity characteristics at a low and high flow. Table 7 provides the regression equations that can be used to calculate depth, velocity, or wetted perimeters at any flow. Table 8 provides the effects on channel geometry with a hypothetical 50 percent reduction in flow over time.

Table 2. Channel characteristics of selected segments of Birch Creek and principal tributaries.

\begin{tabular}{|c|c|c|c|c|c|}
\hline $\begin{array}{l}\text { Stre Description Main Channel } \\
\text { Segment }\end{array}$ & Segment begins & of Segments (mi) & Gage of & Drainage Area & Grodient \\
\hline 1. Birch Creek above Twelvemile Creek & 0 & 1 & 1 & 85 & 0.006 \\
\hline 2. Birch Greek below Twelvemile Creek & 1. & 9 & 6 & 156 & 0.005 \\
\hline 3. Birch Creek above Clums Fork & 10 & 24 & 34 & 436 & 0.003 \\
\hline 4. Birch Creek above Harrison Creek & 34 & 34 & 54 & 763 & 0.004 \\
\hline 5. Birch Creek below South Fork & 68 & 17 & 77 & 1350 & 0.005 \\
\hline 6. Birch Creek at Steese Highway Bridge & 85 & 40 & 126 & 2150 & 0.002 \\
\hline Principal Tributaries & Enters of WRM & & & & \\
\hline Twelvemile Creek at Put-in & 1 & 1 & 1 & 47 & 0.006 \\
\hline Harrington Fork at Birch Greek & 10 & 2 & 10 & 109 & 0.005 \\
\hline Clums Fork at Birch Creek & 34 & 2 & 34 & 169 & 0.006 \\
\hline Harrison Creek at Birch Creek & 55 & 1 & 55 & 120 & 0.008 \\
\hline South Fork at Birch Creek & 68 & 2 & 68 & 324 & 0.006 \\
\hline Crooked Creek at Central & 108 & 1. & NA & 161 & 0.008 \\
\hline
\end{tabular}


Table 3. Monthly mean annual discharge (cfs) for Birch Creek Basin (from Kostohrys and Sterin 1996).

\begin{tabular}{|c|c|c|c|c|c|c|}
\hline Month & $\begin{array}{c}\text { Above }^{\star} \\
\text { Twelvemile } \mathrm{Cr}\end{array}$ & $\begin{array}{c}\text { Below } \\
\text { Twelvemile } \mathrm{Cr}\end{array}$ & $\begin{array}{l}\text { Above }^{\star \star} \\
\text { Clums Fk }\end{array}$ & $\begin{array}{c}\text { Below } \\
\text { Harrison Cr }\end{array}$ & $\begin{array}{c}\text { Below } \\
\text { South Fork }\end{array}$ & $\begin{array}{l}\text { Steese }^{\star} \\
\text { Hwy Br }\end{array}$ \\
\hline Jan & 2.4 & 8.6 & 7.6 & 15 & 29 & 60 \\
\hline Feb & 1.6 & 7.1 & 4.1 & 8.5 & 16 & 41 \\
\hline Mar & 1.2 & 5.3 & 2.5 & 5.8 & 10 & 29 \\
\hline Apr & 18 & 48 & 74 & 152 & 258 & 345 \\
\hline May & 193 & 385 & 745 & 1,480 & 2,430 & 3,790 \\
\hline Jun & 177 & 256 & 473 & 948 & 1,560 & 2,520 \\
\hline Jul & 58 & 138 & 239 & 484 & 807 & 1,240 \\
\hline Aug & 59 & 159 & 279 & 565 & 940 & 1,380 \\
\hline Sep & 61 & 165 & 292 & 591 & 982 & 1,430 \\
\hline Oct & 31 & 65 & 117 & 302 & 406 & 737 \\
\hline Nov & 13 & 29 & 45 & 109 & 161 & 267 \\
\hline Dec & 5 & 15 & 18 & 41 & 66 & 109 \\
\hline Average & 52 & 107 & 199 & 392 & 639 & 997 \\
\hline
\end{tabular}

*Includes USGS and Alaska DNR data

** Estimated from limited data

While both sites exhibit significant reductions in depth and velocity, the site above Twelvemile Creek shows a much larger decrease in wetted perimeter at the lower flow, and a moderate decrease at bankfull

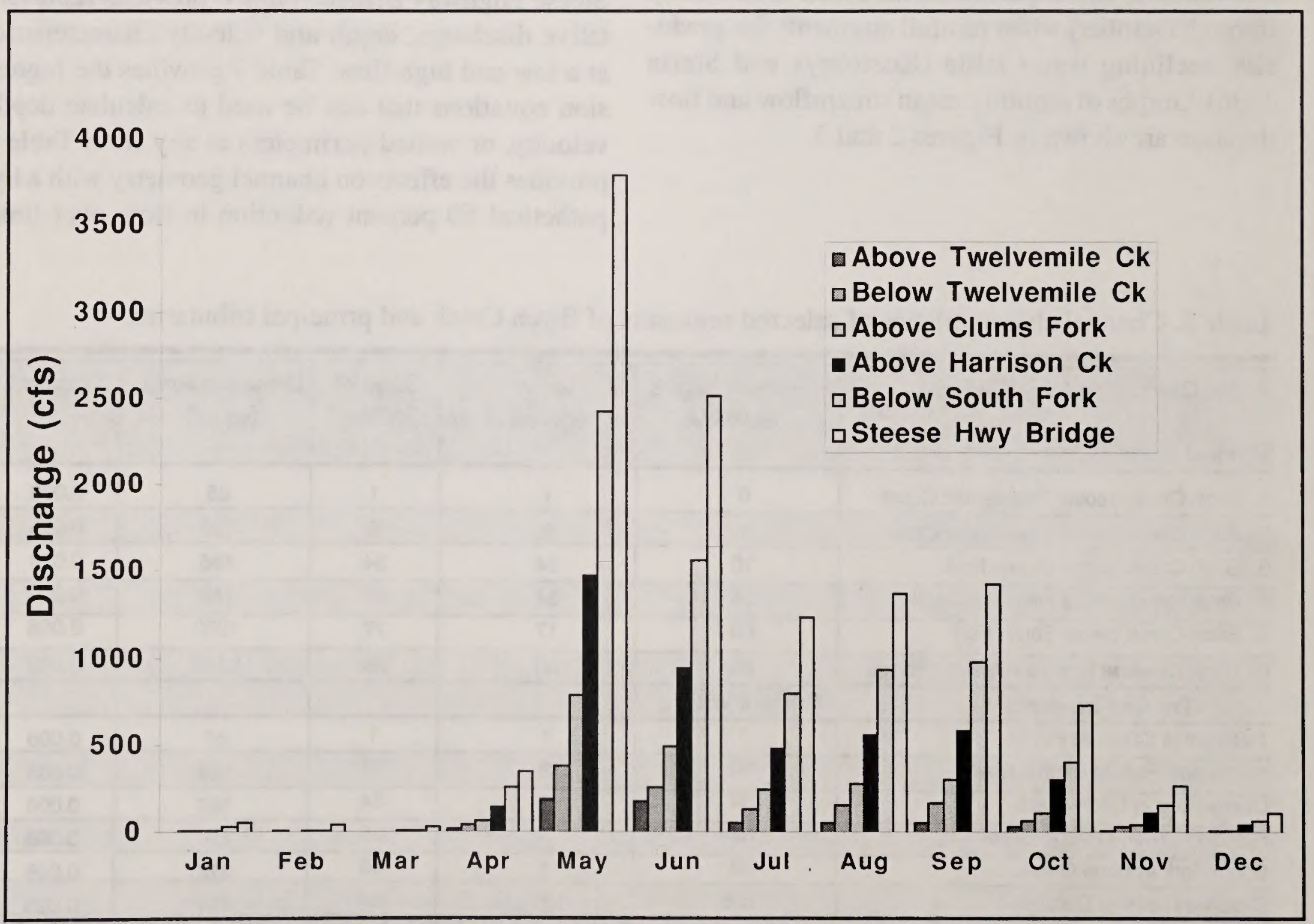

Figure 2. Monthly mean discharge (cfs) for the six Birch Creek segments. 
10000

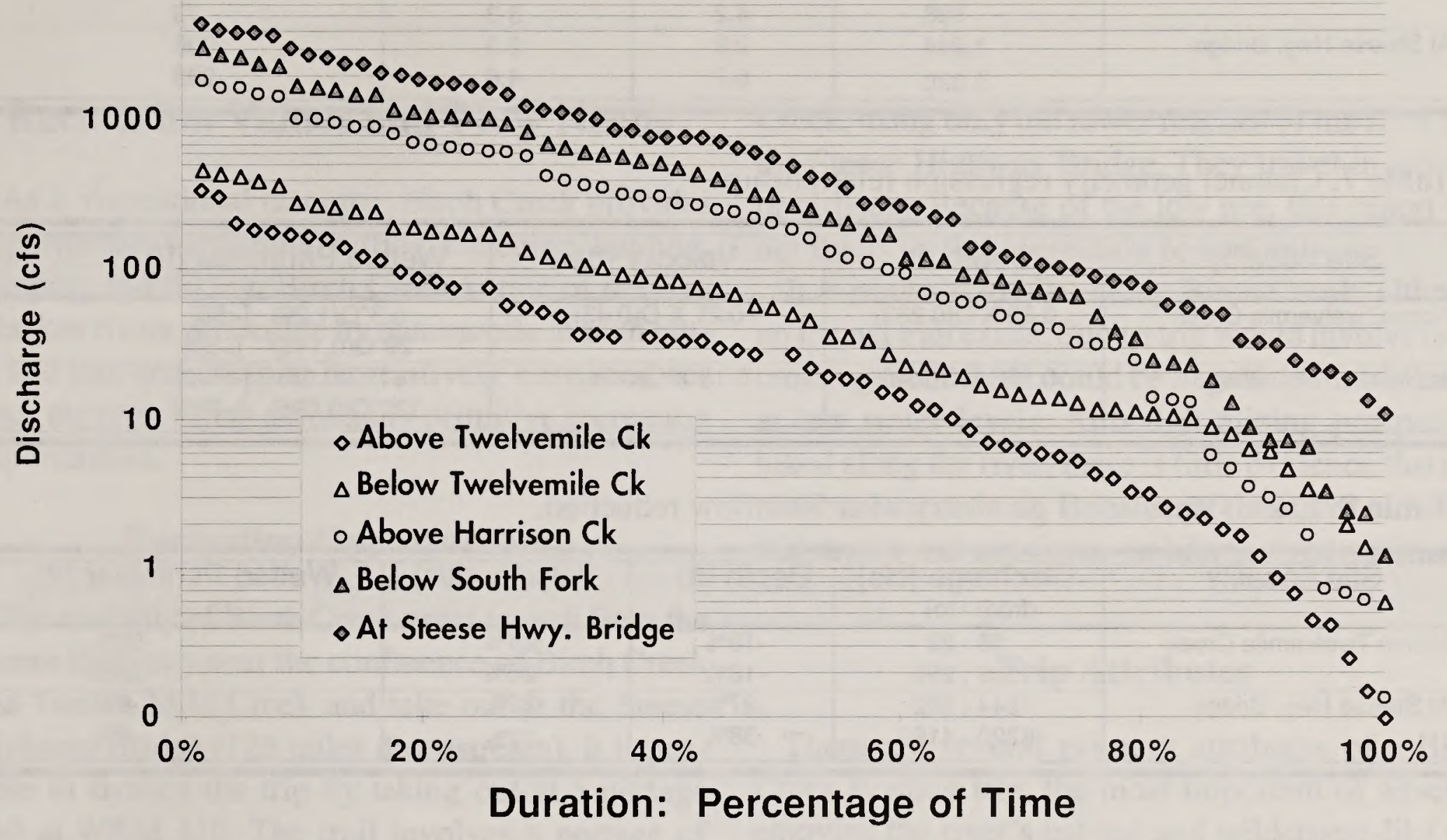

Figure 3. Flow duration curves for the six Birch Creek Basin segments.

Table 4. Log Pearson III instantaneous flow-frequency estimates derived for Birch Creek (discharge in cfs).

\begin{tabular}{c|c|c|c|c|c|c}
\hline \hline $\begin{array}{c}\text { Recurrence } \\
\text { Interval (yrs) }\end{array}$ & $\begin{array}{c}\text { Above * } \\
\text { Twelvemile Ck }\end{array}$ & $\begin{array}{c}\text { Below } \\
\text { Twelvemile Ck }\end{array}$ & $\begin{array}{c}\text { Above ** } \\
\text { Clums Fork }\end{array}$ & $\begin{array}{c}\text { Above } \\
\text { Harrison Ck }\end{array}$ & $\begin{array}{c}\text { Below } \\
\text { South Fork }\end{array}$ & $\begin{array}{c}\text { Steese * } \\
\text { Hwy Bridge }\end{array}$ \\
\hline 2 & 885 & 1,995 & 3,330 & 6,870 & 9,760 & 11,800 \\
\hline 5 & 1,500 & 2,800 & 5,950 & 10,700 & 18,100 & 23,600 \\
\hline 10 & 1,820 & 3,400 & 8,460 & 13,900 & 26,200 & 37,100 \\
\hline 25 & 2,110 & 4,260 & 12,010 & 19,000 & 40,100 & 56,400 \\
\hline 50 & 2,270 & 4,960 & 15,490 & 23,600 & 53,800 & 94,000 \\
\hline 100 & 2,390 & 5,730 & 19,630 & 29,000 & 71,200 & 138,000 \\
\hline \hline
\end{tabular}

*Includes USGS and Alaska DNR data

** Estimated from limited data

Table 5. Bankfull discharge calculated by four different methods and averaged for Birch Creek (discharge in cfs).

\begin{tabular}{l|c|c|c|c|c}
\hline $\begin{array}{c}\text { Site Locality } \\
\text { Birch Creek }\end{array}$ & $\begin{array}{c}\text { Empirical Area Equation } \\
\text { (Emmett) }\end{array}$ & $\begin{array}{c}2-\text { Year Recurrence Flow } \\
\text { (Parks and Madison) }\end{array}$ & $\begin{array}{c}1.5-\text { Year Recurrence Flow } \\
\text { from Gaging Data }\end{array}$ & $\begin{array}{c}\text { Field Survey Data } \\
\text { ( }{ }^{*} \text { insufficient data) }\end{array}$ & $\begin{array}{c}\text { Average } \\
\text { Bankfull Discharge }\end{array}$ \\
\hline AboveTwelvemile Ck & 910 & 764 & 598 & 958 & 807 \\
\hline Below Twelvemile Ck & 1,460 & 1,330 & 1,710 & 1,150 & 1,410 \\
\hline Above Clums Fork & 3,300 & 3,380 & 2,550 & 2,600 & 2,960 \\
\hline Above Harrison Ck & 5,130 & 5,620 & 5,670 & 5,010 & 5,360 \\
\hline Below South Fork & 8,050 & 9,450 & 7,410 & $\star$ & 8,303 \\
\hline At Steese Hwy. Bridge & 11,600 & 14,400 & 8,320 & 8,800 & 10,800 \\
\hline \hline
\end{tabular}


Table 6. Channel geometry at low and high discharge at two sites on Birch Creek.

\begin{tabular}{l|c|c|c|c}
\hline \hline \multicolumn{1}{c|}{ Site Locality } & Discharge (cfs) & Depth (ft) & Velocity (ft/s) & Wetted Perimeter (ft) \\
\hline AboveTwelvemile Creek & 58 & 2.2 & 1.2 & 52 \\
& 598 & 4.2 & 3.3 & 73 \\
\hline At Steese Hwy. Bridge & 1,244 & 2.8 & 2.3 & 236 \\
& 8,320 & 6.7 & 4.6 & 283 \\
\hline
\end{tabular}

Table 7. Channel geometry regression relationships.

\begin{tabular}{l|c|c|c}
\hline \hline \multicolumn{1}{c|}{ Site Locality } & Depth $(\mathrm{ft})$ & Velocity $(\mathrm{ft} / \mathrm{s})$ & Wetted Perimeter $(\mathrm{ft})$ \\
\hline AboveTwelvemile Creek & $0.68 \times \mathrm{Q}(0.283)$ & $0.21 \times \mathrm{Q}(0.43)$ & $0.3^{*} \mathrm{Q}(1.29)[<50]$ \\
& & & $29^{*} \mathrm{Q}(0.145)[>50]$ \\
\hline At Steese Hwy. Bridge & $0.106 \times \mathrm{Q}(0.46)$ & $0.18 \times \mathrm{Q}(0.36)$ & $161^{*} \mathrm{Q}(0.05)[<700]$ \\
& & $120^{*} \mathrm{Q}(0.095)[>700]$ \\
\hline \hline
\end{tabular}

Table 8. Effects on channel geometry with $50 \%$ flow reduction.

\begin{tabular}{l|c|c|c|c}
\hline \multicolumn{1}{c|}{ Site Locality } & $\begin{array}{c}\text { Discharge (cfs) } \\
\text { (from : to) }\end{array}$ & Depth (ft) & Velocity (ft/s) & Wetted Perimeter (ft) \\
\hline Above Twelvemile Creek & $58: 29$ & $-18 \%$ & $-26 \%$ & $-56 \%$ \\
At Steese Hwy. Bridge & $598: 299$ & $-18 \%$ & $-26 \%$ & $-10 \%$ \\
& $1244: 622$ & $-27 \%$ & $-22 \%$ & $-6 \%$ \\
\hline
\end{tabular}

discharge. The site at the Steese Highway Bridge, however, is largely unaffected. Since reductions in wetted perimeter below a critical level may adversely affect fish populations (DNR 1985), reduced streamflow may impact some sites but have little effect on others. The relationships discussed in these analyses were for illustrative purposes only. Changes in flows may have a variety of effects not accounted for in these examples. While useful in general approximations, this type of analysis should be applied only to the specific sites for which the properties have been determined and only within the range of values surveyed. 


\section{Chapter 4. Resource Values AND FLOW NEEDS ANALYSIS}

\section{Recreation Values and Flow Needs}

As a recreational resource, Birch Creek provides opportunities for fishing, rafting, canoeing, hunting, camping and hiking. Birch Creek is one of the few Alaskan rivers accessible by automobile at both putin and take-out. Despite its relatively easy road access, the river offers essentially primitive recreation opportunities.

\section{Recreation Opportunities}

The majority of Birch Creek users launch from the Steese Highway near the confluence of Birch Creek and Twelve Mile Creek and take out at the Steese Highway Bridge (126 miles downstream). It is possible to shorten the trip by taking out at a portage trail at WRM 110. The trail involves a portage of about a quarter mile. The BLM plans to develop a road accessible take-out at this site.

The craft of choice for Birch Creek trips is a canoe, generally ABS or plastic models, although some users take small rafts (typically less than 14 feet long). Trips on the river generally take four to seven days, with a five-day trip the most typical and preferred. At low water levels, users expect to spend more time on the river each day to keep the trip on schedule.

Infrequently, hunters take powerboat trips on Birch

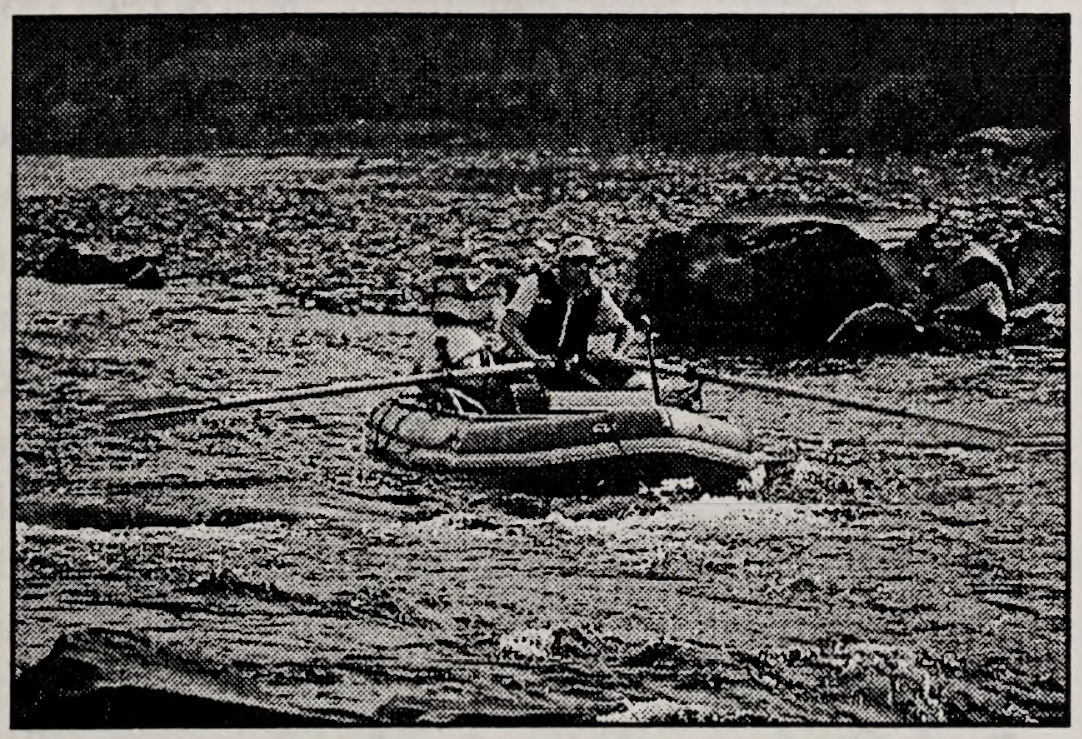

Photo 5. Some boaters use small rafts, although these result in slower rates of travel.
Creek, using only the lower reaches of the river near the Steese Highway Bridge. They travel in jetboats or airboats. Because of the low use, this report will not focus on this recreation opportunity.

It is possible to hike along Birch Creek, although no formal trail exists. Such a trip would involve many crossings, but these could be negotiated fairly easily at low water levels. Although mining prospectors hiked along the river, there is little evidence that recreational users do so. Because of these low numbers, this report will not focus on hiking opportunities.

\section{Trip Attributes}

There are several primary attributes of a Birch Creek floating trip, the most important of which is enjoying the river's natural and wilderness-like setting. Users are interested in traveling down a river that is undeveloped, has few traces of human use, recreational or otherwise, and where natural processes are evident. Opportunities for challenge and risk also figure into this wilderness attribute-users enjoy testing their outdoor skills (running the river, camping, etc.).

Viewing scenery is also associated with this primary attribute. Users taking Birch Creek trips expect open vistas of the river and the adjacent environment, including the mountains beyond the river.

Solitude is another important attribute of float trips. Users agree that a few encounters with other groups are tolerable, but certainly not preferred. They also overwhelmingly prefer to be out of sight and sound of other groups when camping. This river has relatively low use in comparison to many other roadaccessible rivers in the state.

Floatability is the final primary attribute of Birch Creek trips. Users expect to be able to get down the river with a minimum of "hits" (groundings or contact with rocks or gravel bars) or "stops" (when boats become stuck on rocks or gravel bars), and don't want to get out of their boat to drag it across a shallow reach. A more detailed discussion of users' tolerance 
for each of these types of floatability problems is presented later in this report.

A number of secondary attributes also contribute to the quality of Birch Creek float trips, although users do not depend on them to the same degree as they do primary attributes. These include the presence of high quality campsites, challenging whitewater, ability to travel at a reasonable rate, wildlife viewing and fishing.

Camping is an important part of a Birch Creek trip and users prefer to stay at high-quality sites. Good views of the river and adjacent scenery are integral to this quality, as are a minimum number of insects, easy access and places to secure boats, and flat areas for tents and "kitchens." Large gravel bars are often preferred by campers for these reasons. Other attributes of high-quality campsites include isolation from other camps and good water quality.

Whitewater is another important part of Birch Creek trips, although most users note that the two major rapids on the river serve more as a "bonus" rather than a primary reason to float the river. Users enjoy having to make reasonably challenging maneuvers at the two rapids - most boaters are advanced but not expert paddlers and they typically travel in open canoes without floatation. On other parts of the river, users enjoy the variety that comes with small hydraulics and small standing waves that follow riffles. Advanced boaters would prefer more rapids but they expect a Birch Creek float to feature mostly Class I and II water.

Rate of travel is another secondary attribute of Birch Creek trips. Users generally expect to spend five to seven days on the river per trip, and less than seven or eight hours on the river per day. This means they need to average 4 or 5 miles per hour. On some sections, this rate of travel is easy-the current occasionally moves that fast. On others, the water can seem almost still, requiring boaters to paddle or row consistently to maintain pace. Users prefer water levels that provide a reasonable current so the trip does not become too arduous, and so they can spend a sufficient amount of time in camp.

Viewing wildlife is also of interest to Birch Creek users. While the river is not known as a high-quality wildlife viewing area, several species (including moose, black and grizzly bear, wolf, bald eagle, peregrine falcon, and a variety of smaller mammals and waterfowl) are sometimes seen. Likewise, although the river is not well known for its fishing, Birch Creek and its tributaries can produce good-sized grayling when mining impacts remain low for extended periods (at least two to three years). Although users don't take the trip specifically to fish, many fish on their trips.

Table 9 summarizes primary and secondary trip attributes for Birch Creek float trips, providing the basis for examining the effects of flow levels.

\section{Attribute-Flow Relationships: Recreation}

Instream flows can affect trip attributes both directly and indirectly (Shelby, Taylor and Brown 1992). Attribute-flow relationships are described below, beginning with the most direct relationships and ending with more subtle ones. Following these descriptions, "flow preference curves" were developed to integrate all of these relationships into a single evaluation. This overall evaluation is expressed as a curve on a graph showing a single relationship between flow and recreation quality.

Information sources for the attribute-flow relationships and overall evaluations include the resource user interviews, on-site reconnaissance, and professional judgment based on research from other rivers.

\section{Floatability}

Floatability is the only primary attribute directly affected by flow. As streamflows decrease, users are more likely to scrape bottom, hang up on rocks or gravel bars, becoming "stopped" and have to get out of their boat and drag it across shallow reaches. The lack of floatable flows can significantly detract from trip enjoyment.

Developing a defensible relationship between streamflow and floatability requires making assumptions about the equipment and skill levels of the users, defining their tolerance for various "floatability problems" (which also need to be carefully defined), and then determining how often those problems are likely to occur at various flow levels. Based on discussions with river users and resource reconnaissance, we have developed the following set of assumptions, definitions and tolerances for typical Birch Creek trips. Estimates of the streamflow that creates various floatability conditions are then presented for different reaches of the river. 
Table 9. Flow-related trip attributes of Birch Creek float trips.

\begin{tabular}{|l|l|}
\hline \multicolumn{2}{|l|}{ Primary Attributes } \\
\hline Natural/Wilderness Setting & $\begin{array}{l}\text { Remote from development } \\
\text { Few traces of use } \\
\text { Natural process in evidence } \\
\text { Opportunities for challenge/risk } \\
\text { Viewing scenery }\end{array}$ \\
\hline Solitude & $\begin{array}{l}\text { Single party campsites } \\
\text { Few river encounters }\end{array}$ \\
\hline Floatability & $\begin{array}{l}\text { Minimum number of hits, stops or drags } \\
\text { No portages due to log jams/sweepers }\end{array}$ \\
\hline Secondary Attributes & $\begin{array}{l}\text { Natural/aesthetic sites } \\
\text { Scenic views of river } \\
\text { Minimum of insects } \\
\text { Easy access/place to secure boats } \\
\text { Flat areas for tents }\end{array}$ \\
\hline Camping & $\begin{array}{l}\text { Challenging moves required at two rapids } \\
\text { Small waves and hydraulics at other riffles }\end{array}$ \\
\hline Whitewater & $\begin{array}{l}\text { Maintain schedule (15-20 miles/day) } \\
\text { Adequate time for off-river activities } \\
\text { (less than 7 hours on-river per day) }\end{array}$ \\
\hline Rate of Travel & $\begin{array}{l}\text { Abundance of fish } \\
\text { Open bars/banks to fish from }\end{array}$ \\
\hline
\end{tabular}

\section{Assumptions:}

- Users have moderate to advanced boating skills. The river can be negotiated by novice boaters (rapids can be portaged), but most users appear to have significant experience. We interpret a moderately skilled boater as one who has taken his/her craft on at least five trips on rivers with some technical whitewater. For canoeists, ability to run Class II whitewater is assumed; for rafters, proficiency in class III whitewater is assumed.

- All boats and equipment are of good quality and designed for rivers like Birch Creek. Canoes are made of ABS plastic and do not have keels; rafts are multi-chambered and less than 14 feet in length, etc. Other crafts can be used on the river, but most users take high-quality boats and the relationships are developed for this majority.
- Boats are moderately loaded. For canoes, this means one or two passengers and gear for a week's trip. In rafts, three passengers and the equivalent amount of gear is assumed. Rafts and canoes are assumed to have the same floatability problems at the same flow levels. It is rare to have a canoe make safe passage and find that a raft will not. Canoes, being narrower and more maneuverable, can avoid or handle floatability problems with greater ease than rafts, and once aground, they also slide over obstacles more easily. However, based on field experience with both crafts, both have similar flow needs on a river like Birch Creek with mostly riffle/ gravel bar obstacles. 


\section{Definitions of Floatability Problems:}

- Hits refer to times when a canoe or raft hits a rock or gravel bar and is slowed or deflected but not stopped. Hits are the least obtrusive floatability problem. For the purposes of this discussion, hits that occur through inattention or a poor maneuver, even when there is a clear channel, are not counted.

- Stops refer to times when a canoe or raft is "hung up" on a rock or gravel bar. It differs from a hit in that the boat's forward momentum is lost. To get "unstopped," boaters must push off the obstacle with a paddle, an oar, or a foot. Shifting weight in the boat (having a passenger move from one side of the raft to another) may also be required. Stops are also a relatively small floatability problem, unless they happen frequently. Stops due to inattention or a poor maneuver by the boater do not count for the purposes of this discussion.

- Boat drags refers to times when boaters have to physically get out of their boat and drag it across a series of boulders or a gravel bar. It is a more severe floatability problem than a stop. A typical boat drag means pulling the boat across several feet of obstacles. Even a few drags per day can be obtrusive. Drags that are the result of boater error do not count for the purposes of this discussion.

- Portages refer to times when boaters have to drag or carry their boat out of the channel and around some obstacle because of poor floatability conditions. This commonly occurs when there are riverwide sweepers, $\log$ jams, or significant rapids at low water conditions.

- Lining a boat through a rapid is also considered a portage for the purposes of this discussion. Any portage is an intrusion on a Birch Creek trip (at least below Harrington Fork), since most users do not expect them. An exception to this rule concerns inexperienced boaters who portage or line their boats around rapids due to high water and safety concerns.

\section{Tolerances for Floatability Problems}

Table 10 presents a matrix of the number of floatability problems users will generally tolerate per day with five levels of "floatability quality." The five point rating scale is used to allow consistency with other instream flow research (where surveyed users specifically rated various floatability conditions). Discussions with resource users and resource reconnaissance were primary sources of data because the Birch Creek user population was too small for a survey. Numbers in the matrix should be considered general rather than specific tolerances; these are "ball park" figures. The qualitative labels are used for ease of discussion, and are described below:

- Optimum floatability is defined as no problems due to flow levels. In a survey, optimum flows would be defined by a high percentage of users rating floatability conditions as satisfactory.

- Near optimum floatability is defined by minor problems due to low flows. On any given day, a boater may contact a rock or gravel bar, but these will be infrequent, and will very rarely require the boater to push off with a paddle or foot to get back into the channel. In a survey, near optimum conditions would be defined by a majority of users rating floatability conditions satisfactory.

- Marginal floatability is defined by the existence of several problems due to low flows. Boaters would make frequent contact with rocks or gravel bars,

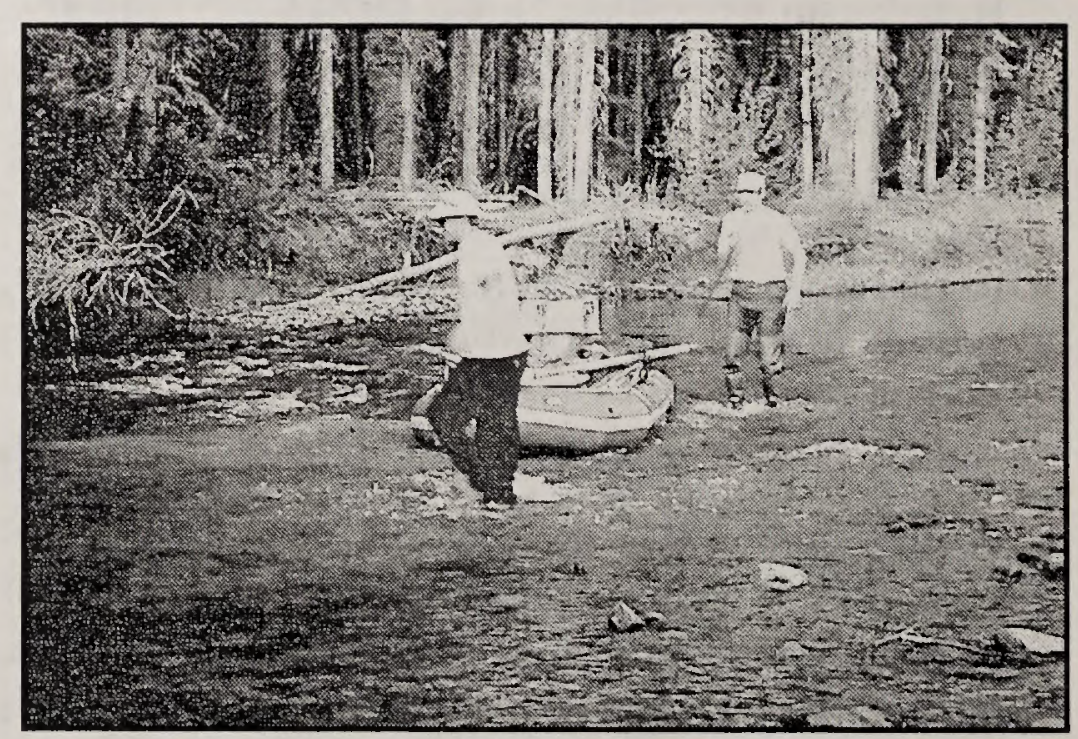

Photo 6. At low flows, boaters may have to pull their craft across shallow bars; the number of boat drags affect trip quality. 
Table 10. User tolerances for floatability problems for Birch Creek per day.

\begin{tabular}{|l|c|c|c|c|c|}
\hline Qualitative Rating & Rating 1-5 & Hits & Stops & Boat Drags & Portages \\
\hline Optimum & 5 & 0 & 0 & 0 & 0 \\
\hline Near optimum & 4 & 3 to 5 & 1 to 2 & 0 & 0 \\
\hline Marginal & 3 & 10 & 3 to 5 & 1 to 2 & 0 \\
\hline Boat Dragging & 2 & 30 & 10 & 3 to 5 & 1 to 2 \\
\hline Unboatable & 1 & constant & 30 & 10 & 3 to 5 \\
\hline
\end{tabular}

become hung up on rocks several times, and may also have to get out of their boats to drag them across shallow reaches a couple of times. In a survey, marginal conditions would be defined by roughly equal numbers rating floatability conditions both satisfactory and unsatisfactory.

- Boat dragging is defined by frequent and obtrusive floatability problems. On a typical day at this water level, boaters will hit bottom more than they can easily count or recall, and they will be frequently "hung up" and need to get out of their boat to pull it across shallow reaches. Portaging around sweepers, log jams or rapids that are unrunnable due to low water may also be required. In a survey, boat dragging would be defined by a majority of users rating conditions as unsatisfactory. Most boaters would not take a trip at these flow levels if they knew ahead of time what the floatability conditions were likely to be.
- Unboatable refers to conditions when floatability problems are almost continuous. At these flows, boats are in constant contact with rocks and gravel bars. Almost every riffle requires boaters to get out of their boat to drag it across shallow reaches, and some rapids are unrunnable. In a survey, unboatable conditions would be defined by a majority of users rating conditions as unsatisfactory. While boaters may still be able to technically navigate a boat and gear down the river, trips taken under these conditions resemble stunts more than recreation experiences.

\section{Flow Estimates for Selected Floatability Conditions}

Table 11 gives estimates of the streamflow that creates optimum, marginal and boat dragging floatability conditions (as described above) for five of the hydrologic segments on the river (boaters do not

Table 11. Threshold flow estimates for selected floatability conditions for Birch Creek (Discharge in cfs).

\begin{tabular}{|c|c|c|c|c|}
\hline Stream Segment & Optinum & Marginal & Boat Dragging & $\begin{array}{l}\text { Juy } 90 \\
\text { Team }\end{array}$ \\
\hline Below Twelvemile Creek & $250+$ & 130 & 60 & 54 \\
\hline Above Clums Fork & $400+$ & 200 & 100 & 78 \\
\hline Above Harrison Creek & $600+$ & 400 & 200 & $130^{*}$ \\
\hline Below South Fork & $600+$ & 400 & 250 & 279 \\
\hline Steese Highway Bridge & $400+$ & 350 & 200 & 558 \\
\hline
\end{tabular}

* estimated 
run Segment 1 and therefore it is not included). These three conditions are the most important levels to use in developing an overall flow preference curve. The flows experienced by the study team (July trip) are also listed in the table for comparative purposes. A brief discussion of these estimates follows:

Segment 2-Twelvemile Creek to Harrington Fork (below Twelvemile Creek): This reach is notorious for its floatability problems throughout the low flow season (most of July and August). However, floaters do not expect to be out of their boat in excess of 30 percent of the time, which is what the team experienced at $54 \mathrm{cfs}$. This was clearly a boat dragging experience and close to unboatable. One hundred and thirty cfs (almost 3 times the experienced flow) was judged necessary to make the trip marginal; an early team trip at $134 \mathrm{cfs}$ was judged to be a marginal trip. Roughly twice that amount $(250 \mathrm{cfs})$ was judged necessary for optimum floatability conditions. This amount of water would allow passage over almost every gravel bar. It should be noted that the narrow width of the river means that some sweeper hazards may have to be portaged at any flow. However, this is part of the wilderness experience on the river, and is generally not correlated with floatability flows.

Segment 3-Harrington Fork to Clums Fork (above Clums Fork): At Harrington Fork, users expect floatability problems to decrease significantly. Flows in July and August are typically in the $200 \mathrm{cfs}$ range above Clums Fork, which would provide a marginal experience. The team experienced $78 \mathrm{cfs}$, which is best described as a boat dragging level; canoeists and rafters had to get out of their boat more than 25 times while traveling this stretch. Optimum conditions were judged to be twice the marginal flow (or four times the flow the team experienced). These flows would create a passable channel through the periodic riffles.

Segment 4-Clums Fork to South Fork (above Harrison Creek): The team continued to experience boat dragging flows through this stretch at about 130

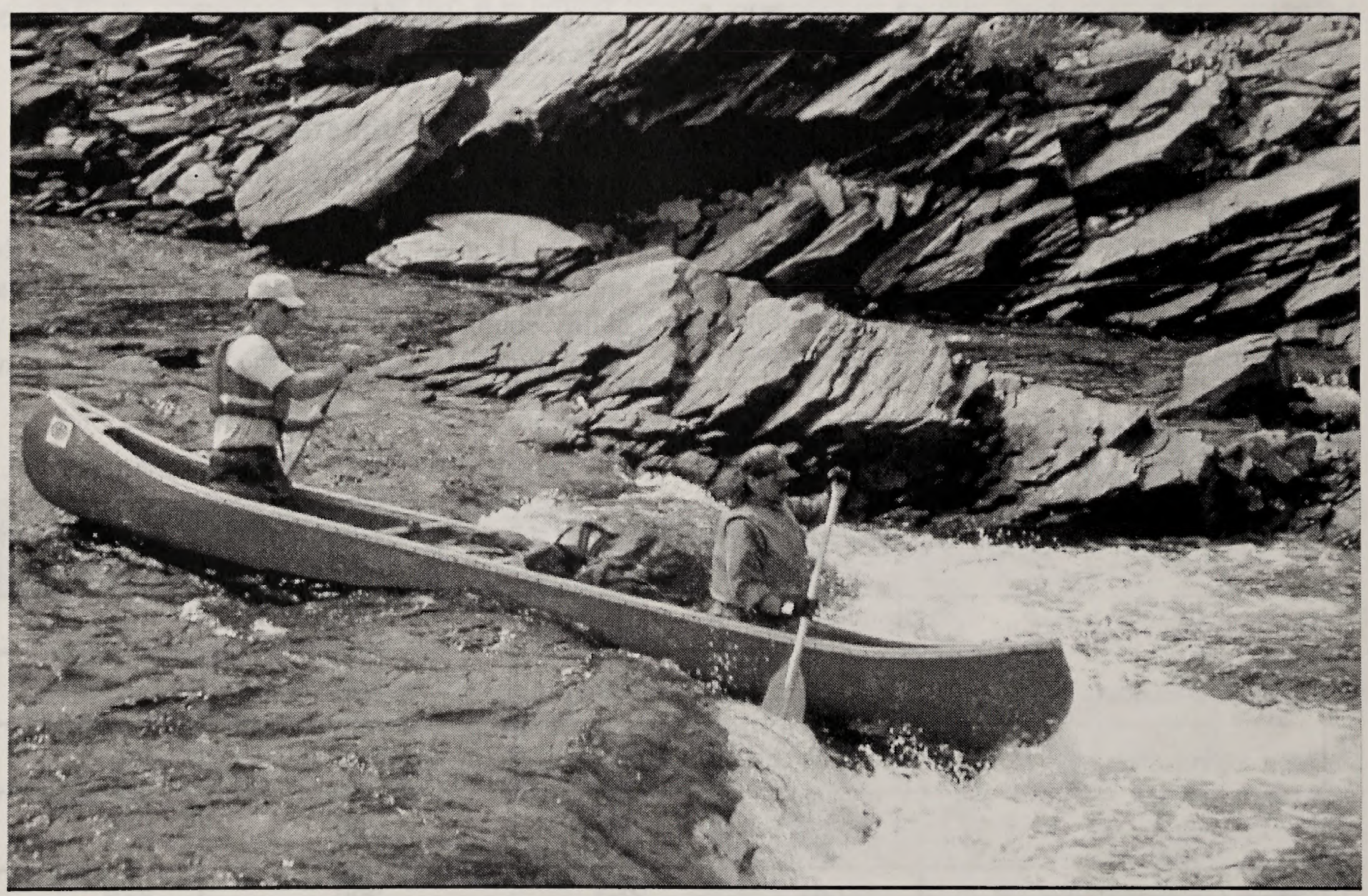

Photo 7. Boaters enjoy the challenge of the rapids on Birch Creek, even though there are few of them. Higher flows provide a greater challenge. 
cfs. The two major rapids were barely runnable, and several riffles (between 12 and 15 ) forced boaters to get out and drag their boat. Low July and August flows are around $200 \mathrm{cfs}$. This was judged likely to provide a boat dragging experience. Marginal flows are estimated at twice the boat dragging flows, or $400 \mathrm{cfs}$. Flows in excess of $600 \mathrm{cfs}$ begin to provide optimum experiences, chiefly because of the increased whitewater challenge.

Segment 5-South Fork to WRM 78 (below South Fork): Below South Fork, the team finally began to see more boatable flows ( $279 \mathrm{cfs}$ ), although conditions were still significantly less than marginal. The river changed from typical "runs and riffles" to long stretches of meanders with occasional riffles. The boat dragging experience occurred at near 250 cfs, with marginal levels at $400 \mathrm{cfs}$. Optimum levels were judged to be close to $600 \mathrm{cfs}$ (clear passable channels would appear at every riffle).

Segment 6-WRM 78 to Steese Highway Bridge (at Steese Highway Bridge): Below Crooked Creek, the river is almost entirely meanders, so floatability issues are unlikely even at relatively low flows. The team experienced $345 \mathrm{cfs}$ at Crooked Creek, which provided marginal floatability conditions. Boat dragging occurs close to $300 \mathrm{cfs}$. Optimum floatability conditions are estimated at over $500 \mathrm{cfs}$.

\section{Whitewater}

Whitewater, although a secondary attribute on Birch Creek trips, is also directly affected by flow.

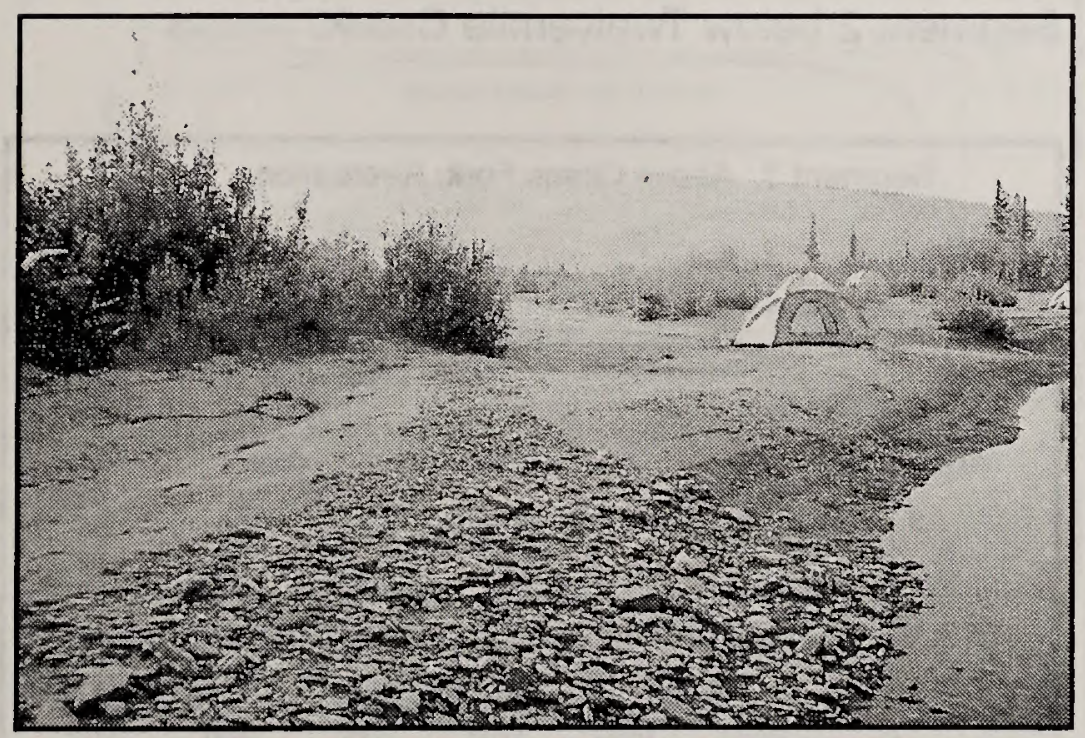

Photo 8 . High quality recreation experiences depend in part on the existence of expansive gravel bars, which are maintained by periodic high flows.
As flows increase, waves and hydraulics generally become bigger and more challenging for floaters. In addition, higher flows increase the number of riffles with significant waves, providing variety from the long stretches of flat water. Because the study team saw rapids at only two different but relatively low water levels, it is difficult to precisely estimate optimum and marginal whitewater conditions. However, based on discussions with resource users and our own professional judgment about how the rapids might change at higher flows, flows at the optimum floatability levels described above would provide marginal whitewater conditions (in a survey, it is estimated that roughly half of the users would rate the whitewater conditions both satisfactory and unsatisfactory). Although these flows would provide variety from the long flat stretches and make the two major rapids sufficiently challenging for many users, they are still a long way from providing optimum whitewater conditions.

Whitewater challenge continues to increase with flow until bankfull levels, when safety becomes an issue. If Birch Creek was known as a whitewater river, this high flow would thus define an optimum. However, because most Birch Creek floaters are less interested in whitewater (and because most travel is in open canoes without floatation bags), preferred whitewater conditions best correlate with flows that keep the two major rapids at or below Class III. Based on resource reconnaissance and discussions with resource users, this occurs at 75 percent of bankfull flow. For the segment with clearly identifiable whitewater (Clums Fork to South Fork), this level is near $3,500 \mathrm{cfs}$.

It is useful to note that many whitewater users also enjoy running rapids at different flow levels on different trips to experience variety. In this sense, a single optimum does not accurately describe how changes in flow result in changes in whitewater preferences. For Birch Creek, there is a range of whitewater "optimums" from optimum floatability conditions up to about 75 percent of bankfull flow.

\section{Rate of Travel}

Rate of travel is another secondary attribute directly affected by flow. As flow increases, it takes less time to get down the river and allows users to take shorter trips or spend more time pursuing off-river activities 
(e.g. camping, fishing or hiking). Based on a typical Birch Creek trip lasting five to six days, with an average of seven and eight hours per day on the river, users must travel an average of four or five miles per hour. Flows at the boat dragging floatability level are not sufficient, and marginal floatability conditions may be lacking The study team experienced boat-dragging levels and found six nights and seven days not enough time to complete the trip. The team chose to portage to the highway at WRM 110 rather than continuing to float the river; the rate of travel at this flow was simply too slow.

In general, optimum floatability flows are necessary for users to feel travel conditions are acceptable. Higher flows would no doubt also be appreciated, particularly by rafters. Optimum canoe rates of travel are equal to floatability optimums.

\section{Other Attributes}

A number of other attributes, including naturalness, viewing scenery, camping, viewing wildlife, and fishing, are indirectly affected by flows. Most of these attributes are associated with the maintenance of near natural flow regimes on the river, and particularly the maintenance of consistent channel maintenance flows. These flows, generally equal to the 1.5-year recurrence flow or bankfull flow, deposit the sediments that create and maintain gravel bars. They also sweep vegetation from those bars, thus providing high-quality campsites and good places to fish. Open gravel bars also increase the number and quality of scenic vistas. Other flows, such as a minimum winter and spring flow, are responsible for maintaining riparian vegetation and channel morphological features that are critical for quality Birch Creek fish and wildlife habitat. Any loss in these channel maintenance flows would also represent a loss in recreational value.

\section{Overall Flow Preference Curves for Recreation}

Overall evaluations of different flow levels are developed for each of the five hydrologic segments relevant for recreation in the following graphs (Figures 4 through 8). Evaluations are expressed as "flow preference curves" and show how recreation quality changes as flows increase. The curves integrate the flow-attribute relationships described above.

All the curves have an inverted " $U$ " shape. This is consistent with previous research on instream flows for recreation (Shelby et al. 1992), and reflects the fact that recreation quality is lower when flow levels are at either extreme (extremely low or extremely high). The curves are primarily based on floatability evaluations, the primary trip attribute most directly affected by flows. In general, the curves rise quickly as flows increase, reflecting that floatability conditions improve relatively quickly as flows increase. Rate-of-travel preferences are also factored into these steep rises, and follow the floatability evaluations.

Team trip flows are also given when available for comparative purposes. "Early team trip" refers to the June reconnaissance. "Team trip" refers to the July reconnaissance taken by the full team. Once

Segment 2. Below Twelvemile: Recreation

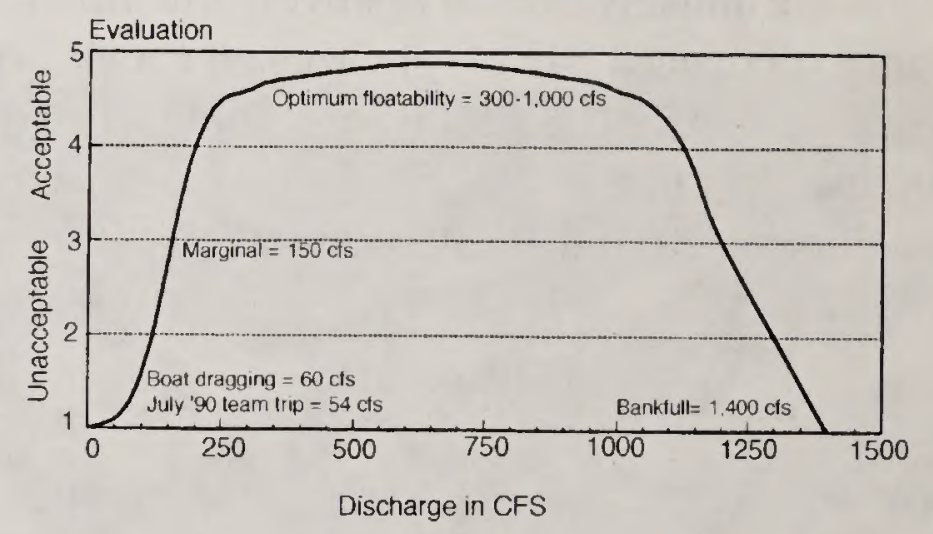

Figure 4. Recreational flow preference curve for Segment 2 below Twelvemile Creek.

Segment 3. Above Clums Fork: Recreation

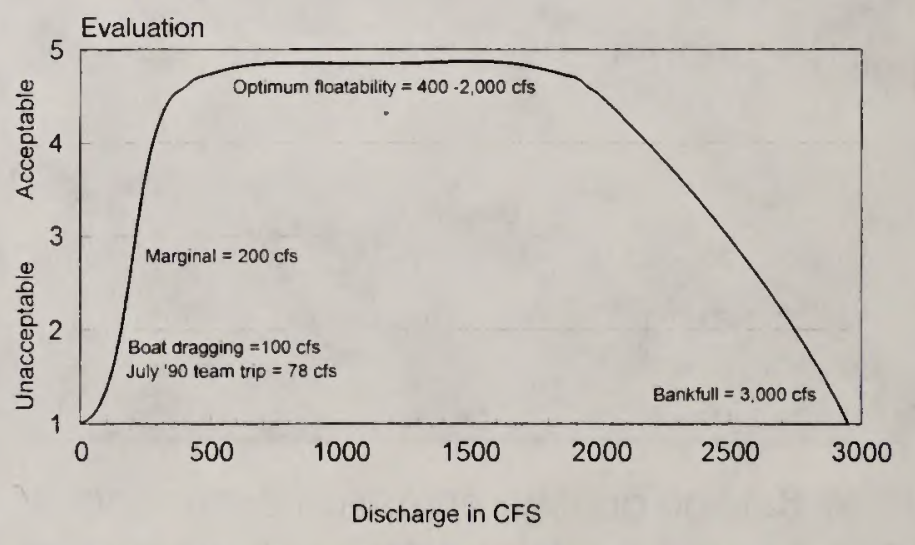

Figure 5. Recreational flow preference curve for Segment 3 above Clums Fork. 
Segment 4. Above Harrison Creek: Recreation

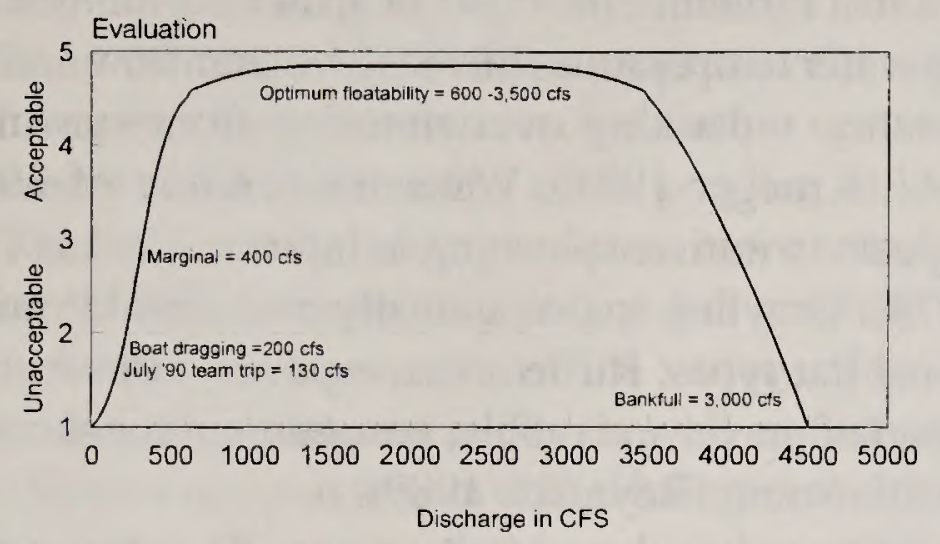

Figure 6. Recreational flow preference curve for Segment 4 above Harrison Creek.

Segment 5. Below South Fork: Recreation

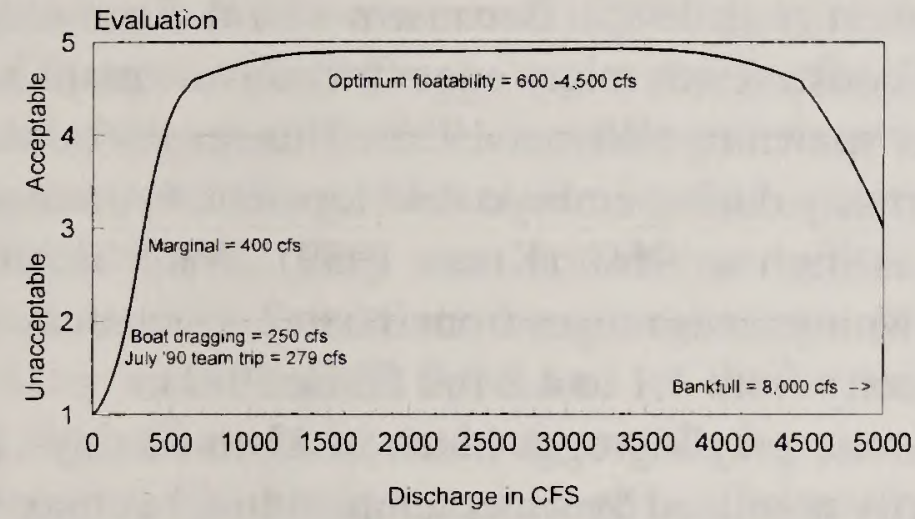

Figure 7. Recreational flow preference curve for Segment 5 below South Fork.

Segment 6. Steese Highway Bridge: Recreation

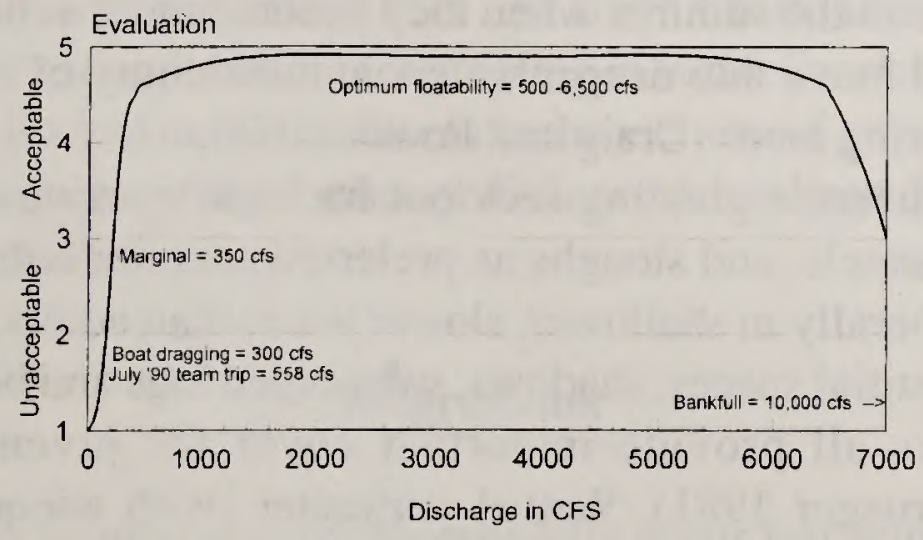

Figure 8. Recreational flow preference curve for Segment 6 at Steese Highway Bridge.

optimum floatability conditions are met, the curves generally flatten out, reflecting that whitewater is a secondary attribute.
Optimum whitewater conditions are best represented as a range. The curves begin to slope back down at roughly 75 percent of bankfull flows in response to safety concerns and the loss of campsites due to high water.

For each curve, five flows are labeled. Optimum flow is expressed as a range (the flat part of the curve) and represents all flows above optimum floatability where whitewater conditions are also desirable. Rateof-travel needs are also met in this range. Marginal flow is expressed as a single point. This is the flow below which a majority of users would be unwilling to take a trip if they knew about the floatability problems that awaited them. It is the point identified as a barely acceptable recreation experience.

Boat dragging flow is also expressed as a single point. This flow defines a type of recreation experience different than floating. A few users may be willing to take this trip on those rare occasions when nature provides only very low flows, but it would not be their trip of choice. Bankfull flow is also expressed as a single point. This is the flow that is needed to maintain the natural integrity of the river. For comparison purposes, the team trip flows are also shown on the curves when available.

\section{Fisheries Resource Values and Flow Needs}

Fish species documented in the Birch Creek drainage, as determined by field surveys done by BLM (Webb 1977, Webb et al. 1985, Kretsinger 1986); Alaska Department of Fish and Game (1987); and

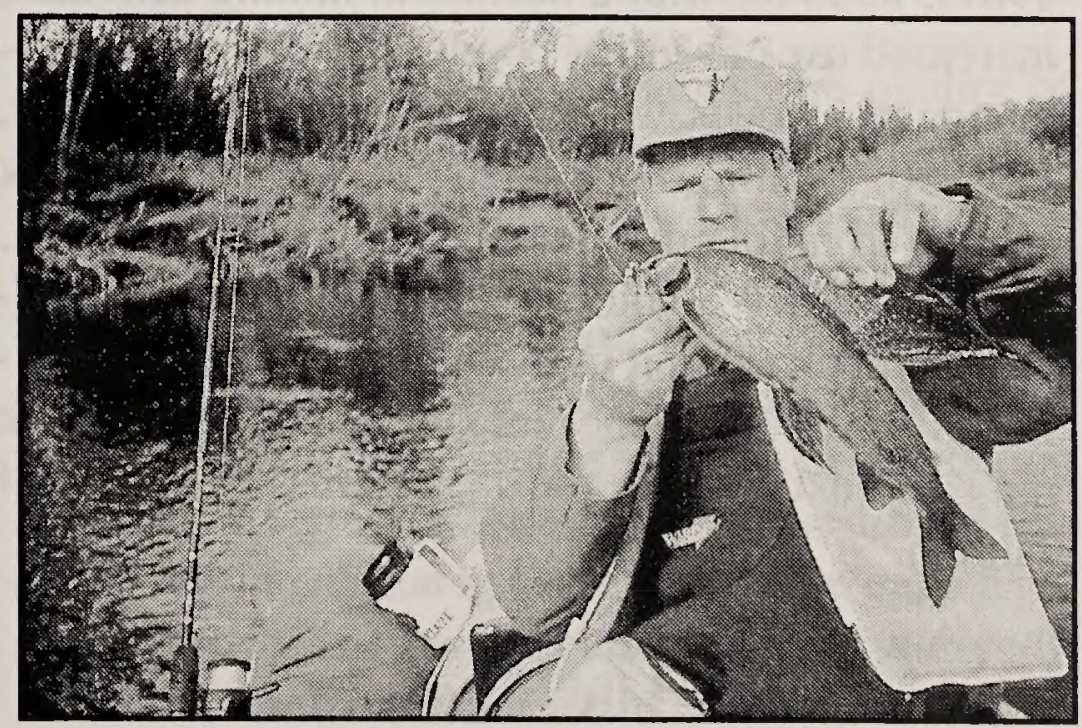

Photo 9. Grayling are found throughout the river; different life stages have different flow requirements. 
others (Gammon 1990) include the following:

- Arctic grayling (Thymallus arcticus)

- Round whitefish (Prosopium cylindraceum)

- Broad whitefish (Coregonus nasus)

- Northern pike (Esox lucius)

- Slimy sculpin (Cottus cognatus)

- Burbot (Lota lota)

- Longnose suckers (Catostomus catostomus)

- Chinook salmon (Oncorhynchus tshanytscha)

- Chum salmon (Oncorhynchus keta)

- Sheefish (Stenodus leucicthys)

This report will focus on Arctic grayling, primarily due to their dominance in the basin and high sport-fish value. Holmes (1981) found grayling to be the most popular sport fish in lnterior Alaska. Arctic grayling are year-round residents in streams and lakes throughout most of Alaska and have been extensively studied, especially in the Interior (Kreuger 1981, Hubert et al. 1985, Armstrong 1986).

From 1972 to 1987 , no salmon were collected or observed in Birch Creek, a period of increased placermining activity in the upper basin. The reductions in fish and invertebrate populations in the basin have been correlated to increased suspended sediment loads corresponding to placer mining activity in the watershed (Alaska Department of Fish and Game 1987). In 1990, with a decline in mining activities, increased use of settling ponds, and improved reclamation techniques, water quality markedly improved. In 1990, Gammon collected 11 juvenile Chinook salmon from four different locations in Birch Creek. In 1995, USFWS and BLM also documented juvenile Chinook salmon in Birch Creek. If salmon continue their re-emergence into the basin, further work may be justified on the instream flow needs of salmon.

\section{Life History}

Arctic grayling in Interior Alaska usually spawn in May, though the period of spawning may range from late April to early July (Armstrong 1986 ). The spawning period is focused on spring breakup. Factors that influence the onset of spawning include rising water temperature, increased streamflow and the distance separating overwintering from spawning sites (Krueger 1981). Water temperature of $39^{\circ} \mathrm{F}$ appears to initiate spawning in Interior Alaska (Tack 1974). Grayling spawn annually over a wide variety of habitat types. Riffle areas, especially those composed of gravel and rubble, are optimum for successful spawning (Reynolds 1989).

Unlike most salmonids, Arctic grayling do not construct redds, but small depressions do result from spawning activities. Males initiate spawning activity and establish territories three to $30 \mathrm{ft}^{2}$. The adhesive eggs of the Arctic grayling are coated by sand and small gravel as they settle to the stream bottom (Hubert et al. 1985). Because a well-defined redd is not constructed, many eggs drift downstream soon after spawning (Warner 1955). This results in heavy mortality during embryo development, estimated to be as high as 96\% (Kruse 1959). Water depth in spawning areas ranges from 0.6 to 2.4 feet and water velocity from 1.1 to $4.8 \mathrm{ft} / \mathrm{s}$ (Tack 1971).

Arctic grayling eggs hatch in 13 to 32 days, primarily regulated by water temperature, but may also be dependent on water depth and velocity (Krueger 1981). The newly hatched fry emerge from the spawning gravels in three to four days to live in areas of quiet water; shallow riffles adjacent to gravel bars, protected areas near streambanks and in backwaters and side channels (Tack 1971). They remain in these quiet waters, often in dense schools, until late in the summer when they become more solitary and move into deeper waters in the vicinity of their rearing areas (Craig and Poulin 1975).

Juvenile grayling seek out backwater areas, side channels, and sloughs as preferred summer habitat, generally in shallower, slower water than adults. Interstitial spaces, shadows, submerged logs and boulders all provide important cover for juveniles (Krueger 1981). Wetted perimeter (with adequate depth) is a good indicator of the quality of habitat, especially for juveniles. Increases in the length of the wetted perimeter are usually expressed as more edge effect that provides cover for survival as well as areas for macro-invertebrate production (Hubert et al. 1985).

Adult grayling prefer deeper pools and glides in 
the mainstem and tributaries during the remainder of the summer. While specific summer feeding and resting habitats for grayling vary with age, studies indicate that larger individuals progressively move to faster and deeper stream reaches farther upstream (Krueger 1981). Generally, adult grayling hold in slower water, while feeding in faster, more turbulent water that has more drifting prey. Adult grayling are sight feeders and consume a wide variety of insect eggs, larvae, pupae and adults as well as fish eggs and fry that occur as stream drift (Hubert et al. 1985).

Arctic grayling overwinter in a wide variety of habitats while larger rivers generally provide suitable winter habitat often dependent on the stream type. Smaller tributaries, especially streams that have a single dominant source, such as spring-fed or bogfed streams, seldom have significant overwintering populations. While overwintering areas are considered limited in Birch Creek, Vogler and Webb (1984) found three open water leads where the stream approaches the Crazy Mountains in the vicinity of Crooked Creek. They were not able to sample for fish to confirm overwintering areas because of the shallow water, limited flows and ice thickness, but did find water quality to be favorable for overwintering fish. Burkholder and Hughes (University of Alaska, unpublished data) found overwintering populations of grayling in Twelvemile Creek, several miles upstream from its confluence with Birch Creek. These fish were concentrated in an isolated, relatively short reach of stream where groundwater upwelling maintained a continuous discharge throughout the winter. They also found grayling overwintering near the confluence of Clums Fork and Birch Creek. In summary, winter habitat for grayling in Birch Creek may be limited to isolated areas in the vicinity of groundwater upwellings, athough little work has been done to confirm this.

\section{Migrations}

Spawning migrations generally occur just prior to or during spring breakup. As noted earlier, rising water temperature and streamflow are apparently the triggers that initiate this migration. Arctic grayling have been shown to travel long distances to spawn, up to nearly 100 miles in some cases (Nelson 1954). While water depth and velocity are not usually limiting at this time due to the high discharge that nor- mally occurs during breakup, flood flows are necessary to keep a silt free substrate that is required for maintaining spawning success (Alaska Department of Fish and Game 1987).

While spawned-out adult fish may remain within the spawning areas, most adults are thought to migrate upstream to summer feeding habitats where food availability and cover are greatest (Krueger 1981). Juvenile grayling often replace adults in the spawning areas or migrate upstream to marginal reaches peripheral to the adult locations during the summer (Armstrong 1986). While water depths greater than $0.6 \mathrm{ft}$ and velocities less than $2 \mathrm{ft} / \mathrm{s}$ are thought to be optimum (Hubert et al. 1985), grayling may hold in areas of lower water velocity and travel or feed for short periods in areas with much faster velocities and higher prey densities (Kreuger 1981).

In the fall, entire populations of grayling migrate downstream out of certain tributaries into the mainstem. (Armstrong 1986). These migrations are thought to be initiated by decreasing water temperatures and streamflow (Krueger 1981). As noted earlier, however, not all grayling leave the tributaries in Birch Creek. Overwintering populations have been located in upstream locations on adjacent basins. While it is presumed that most fish migrate to deepwater pools in the larger rivers, some grayling have been located in ice-covered, shallow glides and peripheral areas adjacent to riffles (Lubinski personal communication). A summary of grayling usages (a periodicity chart) for Birch Creek is given in Table 12.

\section{Mining Effects on Fisheries}

Outside of the undisturbed areas, the quality of aquatic habitat in Birch Creek has been altered to some degree by mining activity. The primary effect of upstream placer mining on areas where no disturbance has occurred is silting in of the stream bottom substrate (Weber and Post 1985). High levels of total suspended solids during spawning or incubation can result in significant mortality from sediment filling in the interstitial spacing where the eggs have attached to the substrate. Coating the eggs with sediment causes suffocation. Loss of this interstitial spacing also impacts the survival of fry, juveniles and macroinvertebrates (Reynolds et al. 1989).

While a bankfull or two-year flood event would 
Table 12. Grayling usage of Birch Creek. (Source: BLM Field Trip Reports)

\begin{tabular}{|l|c|c|c|c|}
\hline \multicolumn{1}{|c|}{ Month } & $\begin{array}{c}\text { Adults } \\
\text { (feeding/resting) }\end{array}$ & $\begin{array}{c}\text { Adults } \\
\text { (spawning) }\end{array}$ & $\begin{array}{c}\text { Eggs } \\
\text { (incubated) }\end{array}$ & $\begin{array}{c}\text { Fry } \\
\text { (rearing) }\end{array}$ \\
\hline January & possible & & & possible \\
\hline February & possible & & & possible \\
\hline March & possible & & & possible \\
\hline April & confirmed & possible & possible & confirmed \\
\hline May & confirmed & confirmed & confirmed & confirmed \\
\hline June & confirmed & confirmed & confirmed & confirmed \\
\hline July & confirmed & & confirmed & confirmed \\
\hline August & confirmed & & & confirmed \\
\hline September & confirmed & & & confirmed \\
\hline October & confirmed & & & confirmed \\
\hline November & possible & & & possible \\
December & possible & & & possible \\
\hline
\end{tabular}

probably flush most of the silt layering the surface of the streambed, the matrix would remain embedded with finer particles until a higher flood event redistributed the streambed gravels (Dames and Moore 1986).

Macroinvertebrates in the watershed also reflect the effects of placer mining activity. Mayflies, stoneflies, caddis flies and blackflies are abundant in undisturbed habitat and occur rarely, if at all, at mining sites and areas downstream from mining (Weber and Post 1985). While recolonization may begin as quickly as two years after the cessation of mining activity, restoration of the natural habitat would require complete flushing of silt from the streambed matrix, stabilization of tailings piles, the streambed and banks as well as the re-establishment of stream bank and floodplain vegetation (Dames and Moore 1986).

\section{Attribute-Flow Relationships: Fisheries}

Instream flows can affect fisheries attributes both directly and indirectly. Direct effects include changes in quantity and quality of habitat for all life stages, variability in fish passage and water quality. Indirect effects include loss of macrobinvertebrate habitat and subsequent depletion of food availability. Based on the previous life history summary, Table 13 shows habitat parameters judged to be optimal for Arctic grayling (Krueger 1981, Hubert et al. 1985, Reynolds 1989).

Backwaters are those peripheral areas of reduced velocity separated from the main flow by logs, boulders, emergent vegetation or gravel bars. Arctic grayling require streamflows large enough to flood these peripheral habitats. As noted earlier, the change in wetted perimeter indicates when peripheral areas are submerged. The wetted perimeter increases rapidly with increasing streamflow until the entire channel bottom is covered with water, then changes only slightly until the stream banks are over-topped. In larger rivers (greater than 100 feet wide), it has been shown that as specific streamflows meet the selected criteria of depth and velocity, a percentage of the wetted perimeter can be used as the criteria for the minimum flows (Prewitt and Carlson 1977). They specified optimum streamflow as the flow above which little change in wetted perimeter occurs with additional discharge. For Birch Creek, Figures 9-14 contains plots of streamflow versus wetted perimeter. On each graph, there is a major break in slope (inflection point) that corresponds to complete submergence of the entire channel bottom. Discharges below this inflection point would eliminate important peripheral areas required by grayling fry throughout spring and summer. Also plotted is the flow that provides at least 60 percent of the wetted perimeter and the flow that submerges peripheral (backwater) areas to a depth of at least 0.5 feet. While there is some variability in the order of these plots, probably due to variability within the channel geometry of the different cross-sections, they allow for a range of discharges to approximate minimum and optimum flows. Results are summarized in Table 14. 


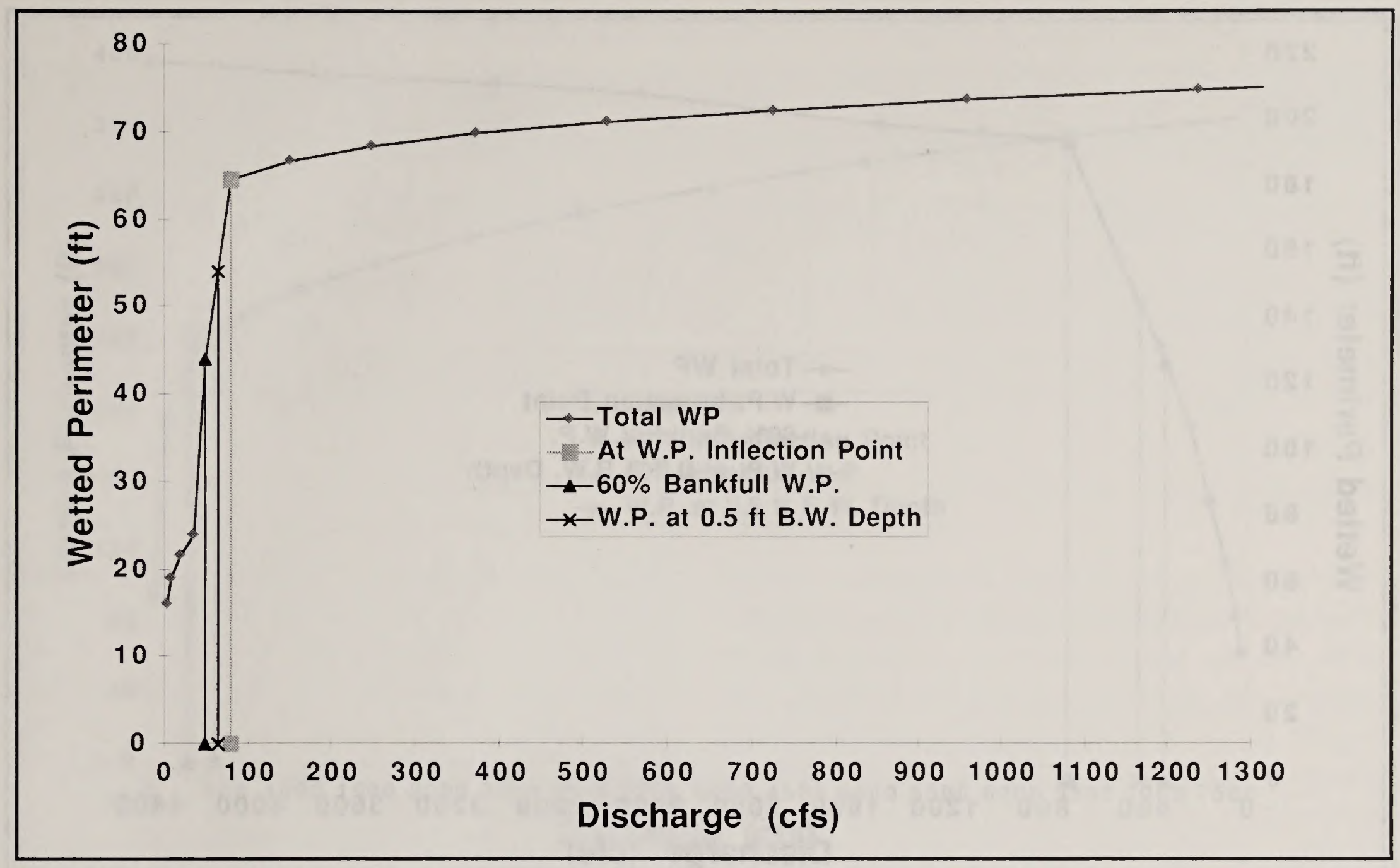

Figure 9. Wetted perimeter vs. discharge plot for Birch Creek above Twelvemile Creek.

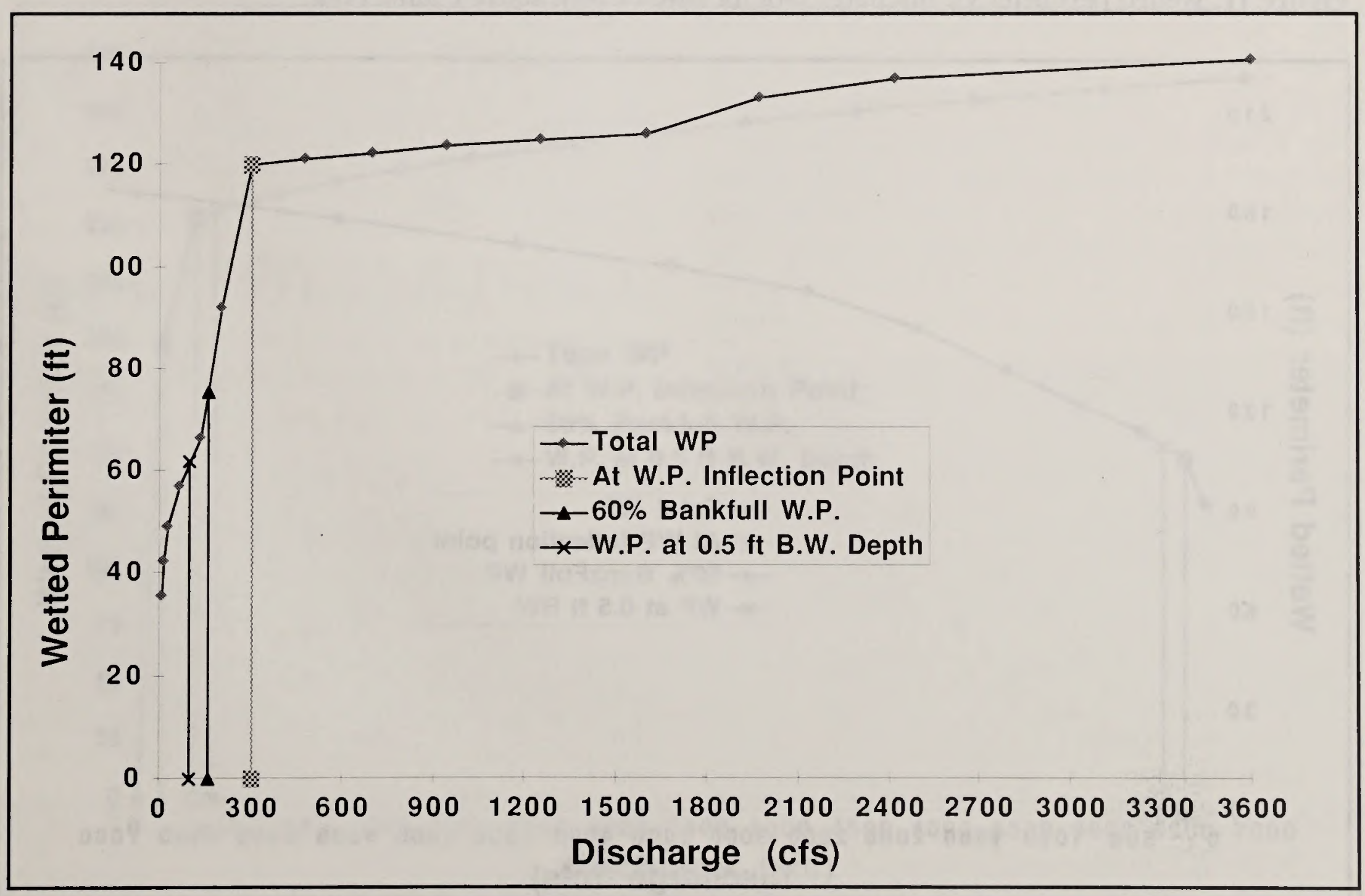

Figure 10. Wetted perimeter vs. discharge plot for Birch Creek below Twelvemile Creek. 


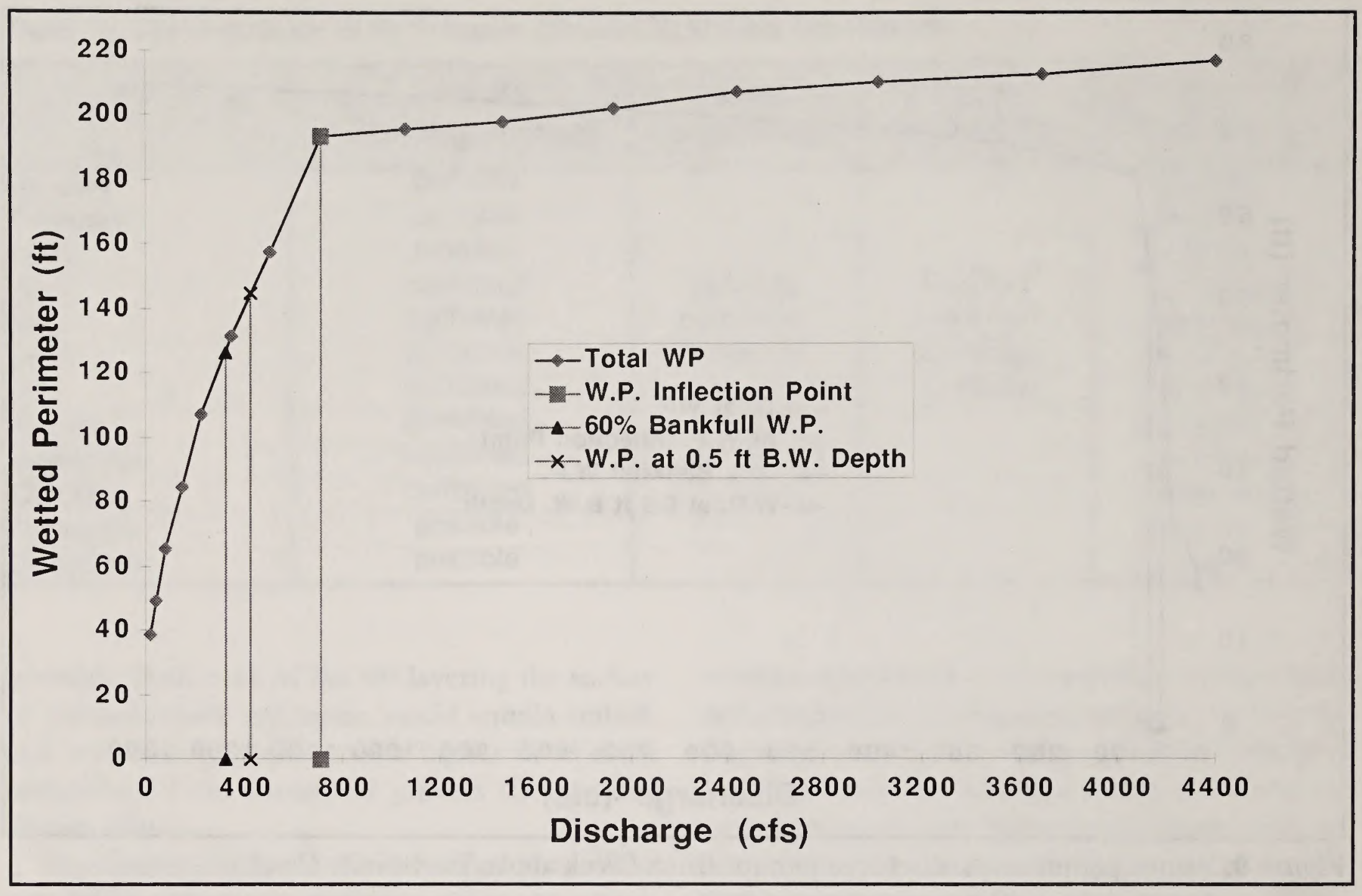

Figure 11. Wetted perimeter vs. discharge plot for Birch Creek above Clums Fork.

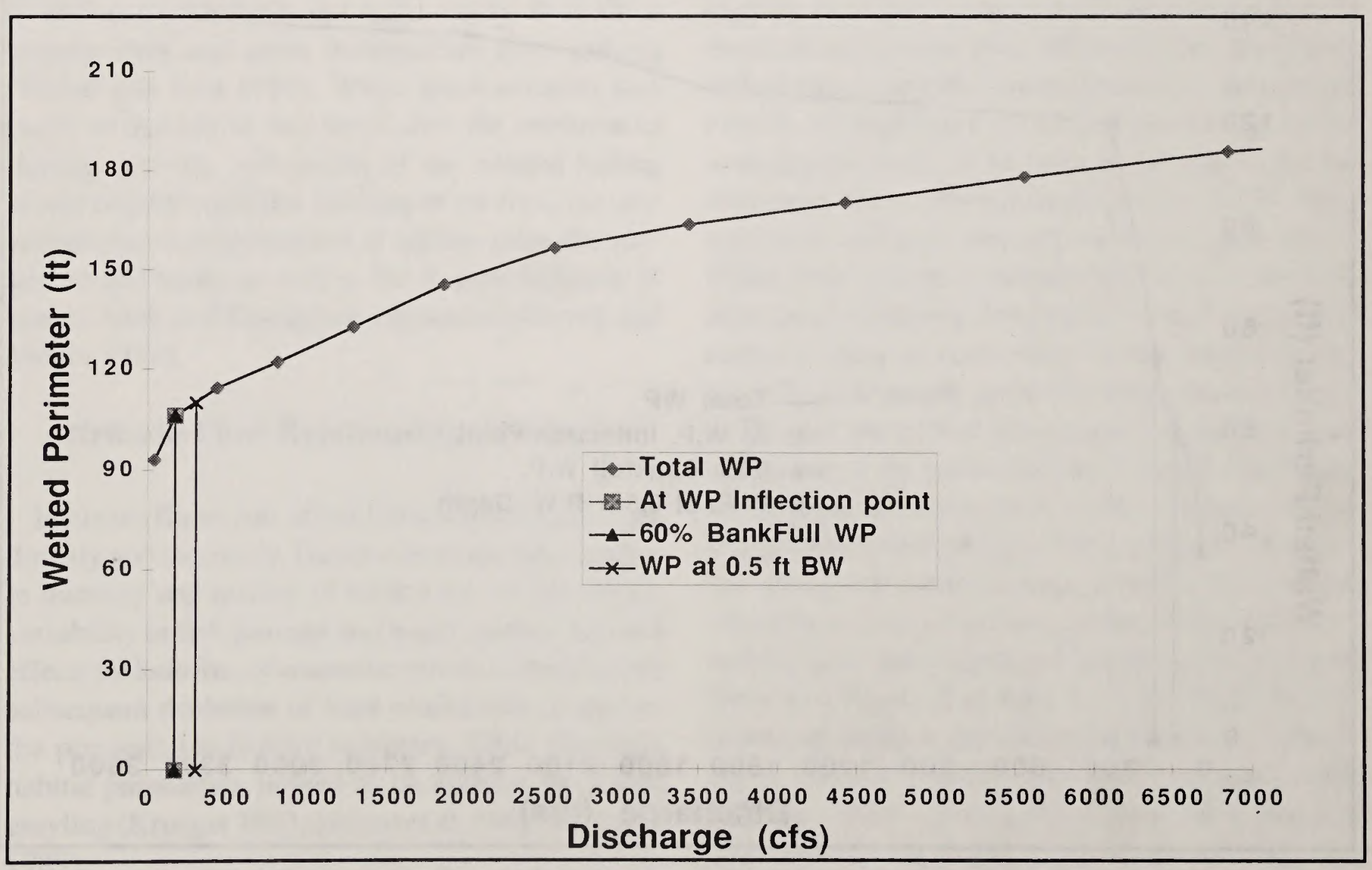

Figure 12. Wetted perimeter vs. discharge plot for Birch Creek above Harrison Creek. 


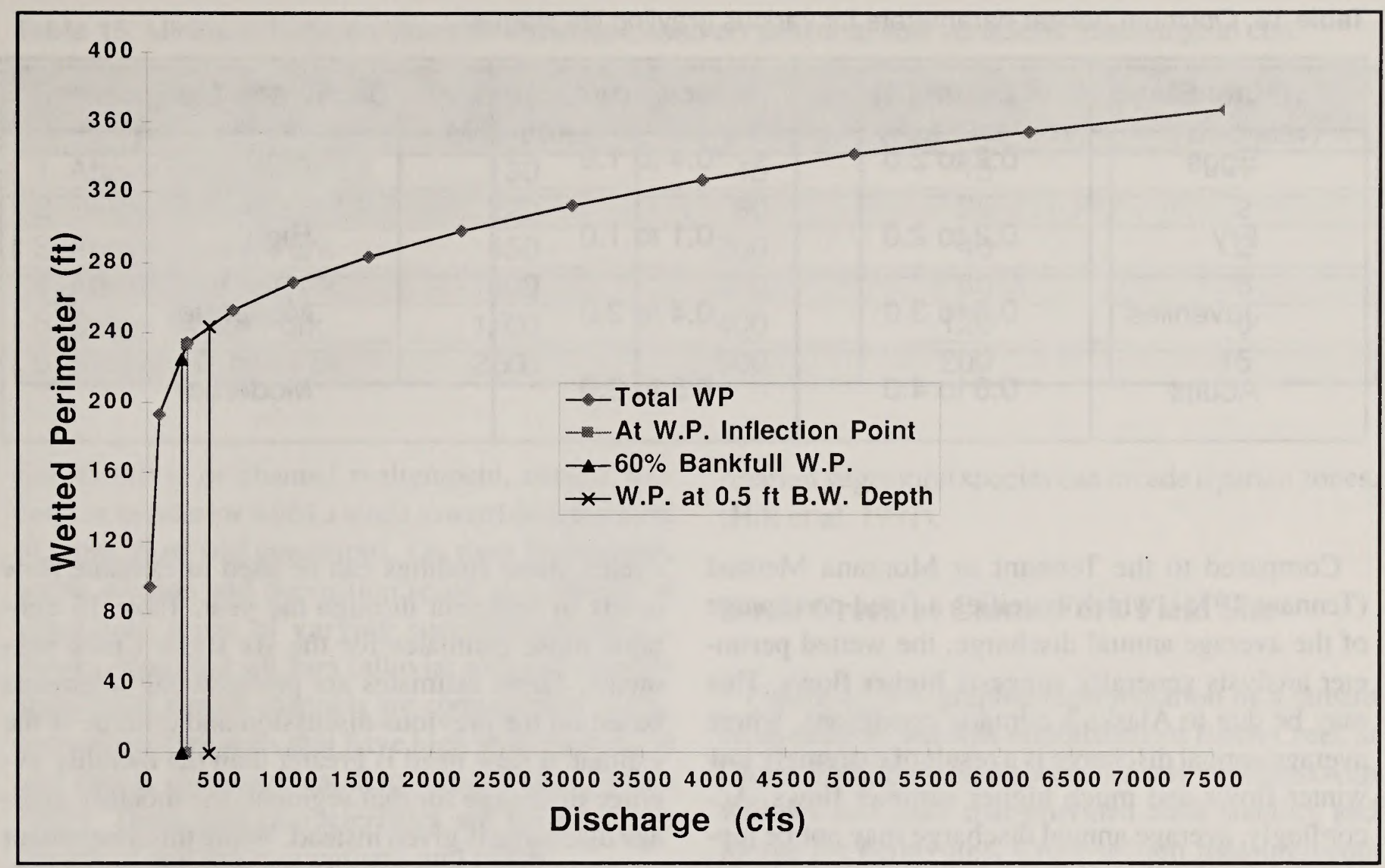

Figure 13. Wetted perimeter vs. discharge plot for Birch Creek below South Fork.



Figure 14. Wetted perimeter vs. discharge plot for Birch Creek at Steese Highway Bridge. 
Table 13. Optimum habitat parameters for various grayling life stages.

\begin{tabular}{|l|l|c|c|}
\hline Life Stage & Depth (ft) & Velocity (ft/sec) & Backwater Usage \\
\hline Eggs & 0.2 to 2.0 & 0.4 to 1.6 & High \\
\hline Fry & 0.2 to 2.0 & 0.1 to 1.0 & High \\
\hline Juveniles & 0.3 to 3.0 & 0.4 to 2.0 & Moderate \\
\hline Adults & 0.6 to 4.0 & 0.5 to 2.0 & Moderate \\
\hline
\end{tabular}

Compared to the Tennant or Montana Method (Tennant 1975), which specifies a fixed percentage of the average annual discharge, the wetted perimeter analysis generally suggests higher flows. This may be due to Alaska's climatic conditions, where average annual discharge is a result of extremely low winter flows and much higher summer flows. Accordingly, average annual discharge may not be representative of either of these critical periods. In determining the flows for a particular period, consideration was given to a particular usage of habitat by fish during that period, and the relationship of flow availability to flow needs for that time. Generally, the breakup and early summer streamflow requirements are calculated as 25 percent of the average bankfull flows (Table 5); the summer flows are based on the depth and wetted perimeter calculations (Figures 9 through 14 and Table 14). The migration and winter flows are based on 90 percent of average monthly flows.

Taken together with information about grayling life cycles, these findings can be used to estimate flow needs by segment through the year. Table 15 contains those estimates for the six Birch Creek segments. These estimates are professional judgments based on the previous discussion and criteria. If the estimated flow need is greater than the monthly average discharge for that segment, the monthly average discharge is given instead. While this assessment attempts to estimate the flows that would provide optimal conditions, we recognize that nature may not always provide them.

The fishery also requires channel maintenance flows in the spring or early summer to flush gravels. The required flows for this function are discussed in the following section on riparian and channel maintenance flow needs.

\section{Riparian Values and Flow Assessment}

Unless a site is drastically disturbed, usually by

Table 14. Minimum instream flows for fisheries using different criteria (discharge in cfs).

\begin{tabular}{|l|c|c|c|c|}
\hline Stream Segment & $\begin{array}{c}\text { Inflection } \\
\text { point of wetted } \\
\text { perimeter and } \\
\text { discharge }\end{array}$ & $\begin{array}{c}\text { Minimum of } \\
60 \text { percent of } \\
\text { usable } \\
\text { wetted } \\
\text { perimeter }\end{array}$ & $\begin{array}{c}\text { Minimum } \mathbf{0 . 5} \\
\text { feet of depth in } \\
\text { backwater or } \\
\text { verge areas }\end{array}$ & $\begin{array}{c}\text { Minimum of } \mathbf{6 0} \\
\text { percent of } \\
\text { average } \\
\text { annual dis- } \\
\text { charge }\end{array}$ \\
\hline 1. Above Twelvemile Ck & 79 & 46 & 63 & 31 \\
\hline 2. Below Twelvemile Ck & 303 & 158 & 97 & 64 \\
\hline 3. Above Clums Fork & 711 & 320 & 424 & 119 \\
\hline 4. Above Harrison Ck. & 171 & 163 & 304 & 235 \\
\hline 5. Below South Fork & 276 & 235 & 432 & 383 \\
\hline 6. Steese Highway Br. & 343 & 145 & 460 & 598 \\
\hline
\end{tabular}


Table 15. Minimum instream flows for fisheries based on seasonal flow variations (discharge in cfs).

\begin{tabular}{|l|c|c|c|c|}
\hline Stream Segment & $\begin{array}{c}\text { Breakup Flow } \\
\text { (May-June) }\end{array}$ & $\begin{array}{c}\text { Summer Flow } \\
\text { (July-Sept) }\end{array}$ & $\begin{array}{c}\text { Migration Flow } \\
\text { (Apr/Oct-Nov) }\end{array}$ & $\begin{array}{c}\text { Winter Flow } \\
\text { (Dec-Mar) }\end{array}$ \\
\hline 1. Above Twelvemile Ck & 130 & 45 & 15 & 1 \\
\hline 2. Below Twelvemile Ck & 220 & 80 & 25 & 2 \\
\hline 3. Above Clums Fork & 450 & 200 & 40 & 2 \\
\hline 4. Above Harrison Ck. & 800 & 300 & 80 & 5 \\
\hline 5. Below South Fork & 1,500 & 400 & 120 & 8 \\
\hline 6. Steese Highway Br. & 2,500 & 500 & 200 & 15 \\
\hline
\end{tabular}

fire, flooding or channel realignment, natural succession in Interior Alaska tends toward development of permafrost soil conditions. On river floodplains, active erosion and deposition result in a mosaic of vegetation types of varying successional stages. Newly deposited silt bars (alluvial soils) or recently abandoned stream channels are composed of warm, permafrost-free soils that have high nutrient content and cation exchange capacity (Juday and Zasada 1982). These soil characteristics are favorable for growth of soil microorganisms and plants.

In the taiga environment (subarctic evergreen forest), disturbance caused by high flow events often determine the distribution of permafrost, and hence the riparian vegetation communities (Van Cleve et al. 1986). The primary determinant of the plant communities in riparian areas is the time since the river deposited the substrate. For example, flood events alter channel morphology by creating oxbows, point bars and side bars. Deposited silt and abandoned river channels are free of permafrost, are nutrient rich, and are rapidly. colonized by early successional plants. High flows, when accompanied by ice flows, scour gravel bars, thus creating seedbeds or shear off Salix willow spp. and Populous spp., which rebound quickly by sprouting and suckering. Finally, extreme flood events that inundate the floodplain remove insulating duff and moss, which permits soil temperatures to rise, thus creating more productive growing conditions.

In addition to determining location of permafrost soils by erosion and deposition, high flow events (especially overbank flows) have major effects on seed dispersal, seedling survival and growth of riparian vegetation. Floodplains also receive large quantities of nutrients, silt and organic matter during overbank floods that serve to maintain riparian communities in a productive growth. If flooding is reduced, non- riparian vegetation species can invade riparian zones. (Hill et al. 1991).

\section{Birch Creek at Clums Fork Field Site}

Figure 15 is a graphic representation of a stream cross-section that was established on Birch Creek at Clums Fork. Both banks were densely vegetated with willows and alder that provided bank stability and forage for herbivores. Cross-section measurements did not include the floodplain area, which is where most of the riparian vegetation communities occur. However, examining topographic maps and aerial photos indicates that the Clums Fork site is representative of the reach below Harrington Fork: a broad floodplain maintained by periodic inundation, with sweeping meanders that create sloughs, and erosional processes that deposit warm, nutrient-rich silt that helps produce productive riparian vegetation communities.

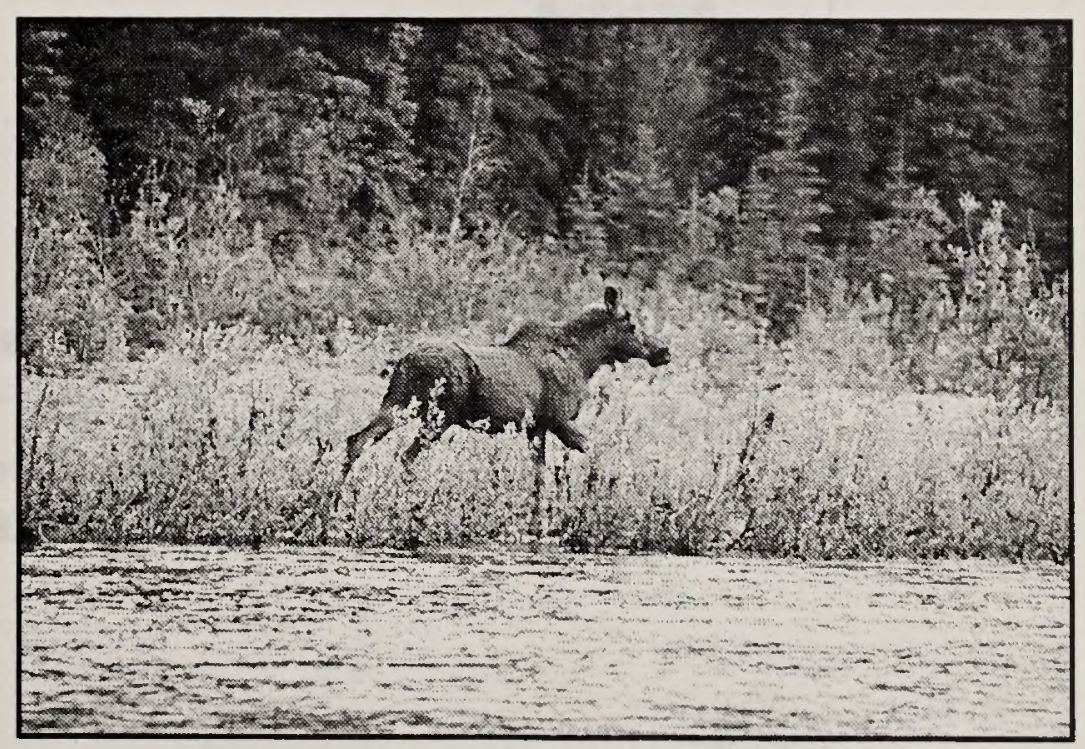

Photo 10. A healthy riparian zone provides good habitat for moose and other wildlife. High flow events are neccessary to ensure highly productive early successional vegetative communities. 


\section{Channel Maintenance}

Flood events equal to average bankfull flows would keep woody vegetation from encroaching upon the main channel, scour gravel bars and create seed beds. Periodic sedimentation through flood events also raises the level of stream terraces and replenishes the mineral soils, accelerating the early stages of plant succession. These flows typically occur in May or June in Interior Alaska, and should be allowed to occur whenever environmental conditions produce them. This channel maintenance flow for the six segments is given in Table 16.

\section{Minimum Streamflow}

Though it is of primary importance to ensure continuation of flood events, it is also important to ensure a certain minimum instream flow during the summer. July and early August are moisture-limiting for plants in the Interior, especially newly established seedlings on exposed gravel bars. As flow levels drop, the ground water table begins to recede, and shallowly rooted seedlings will wither if they are unable to get moisture. Older perennial plants usually have root systems that extend down to more reliable soil moisture, and hence are more likely to survive a drought. However, low flows required to maintain fish populations and recreational values will likely be sufficient to maintain seedling riparian vegetation.

Deciduous forests and shrublands in Interior Alaska that are growing on productive alluvial soils provide substantial amounts of browse. These areas, considering their relative availability on the landscape, are disproportionately important to herbivores and support relatively high populations of moose, hares, microtines and invertebrates. Large "oldgrowth" white spruce and large decadent balsam poplar growing in riparian areas provide habitat for cavity nesters such as marten, northern flying squirrel, boreal owls, hawk owls, woodpeckers, chickadees, bufflehead ducks, common mergansers and other species.

While no literature has been found to quantify minimum streamflow requirements for vegetation in Alaska, Viereck (1993) found that river levels had a much greater effect than precipitation on plant succession in the Tanana River floodplain. Streamflow

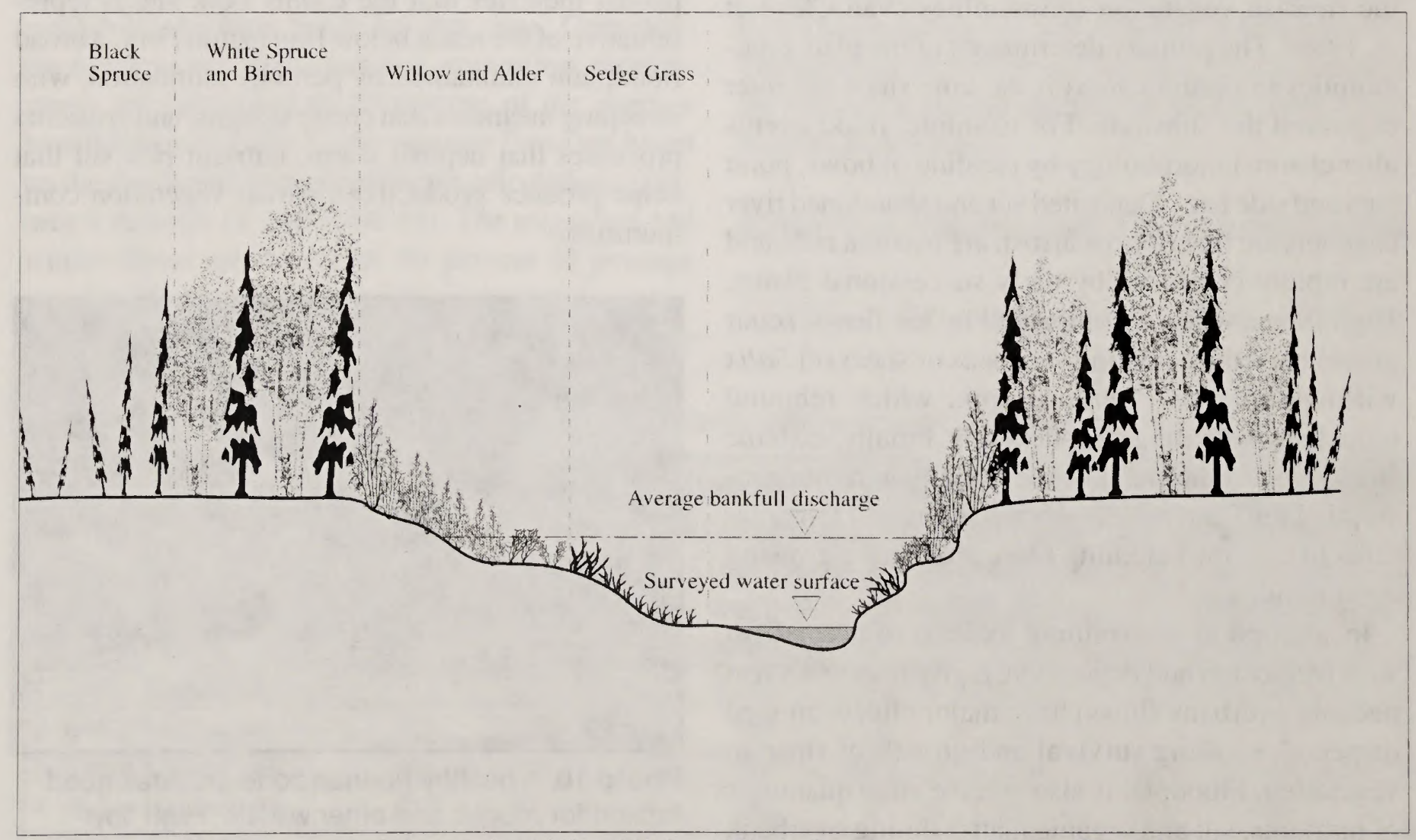

Figure 15. Cross-section of channel and floodplain at Birch Creek above Clums Fork showing vegetation zonation. 
sufficient to fill the low water channel (thalweg), as determined from cross-sectional surveys and discharge ratings during the moisture limiting months of June and August, and slightly higher flows in June to distribute and germinate seeds, would likely be sufficient to maintain seedlings colonizing new sites. These flows are identified for each segment and month in Table 16.

Table 16. Riparian channel and floodplain maintenance flows for Birch Creek (discharge in cfs).

\begin{tabular}{|l|c|c|c|}
\hline \multicolumn{1}{|c|}{ Stream Segment } & $\begin{array}{c}\text { Average Bankfull } \\
\text { Discharge }\end{array}$ & $\begin{array}{c}\text { Minimum discharge } \\
\text { for June }\end{array}$ & $\begin{array}{c}\text { Minimum discharge } \\
\text { for July/Aug }\end{array}$ \\
\hline 1. Above Twelvemile Creek & 807 & 79 & 46 \\
2. Below Twelvemile Creek & 1,410 & 200 & 96 \\
3. Above Clums Fork & 2,960 & 384 & 185 \\
\hline 4. Above Harrison Creek & 5,360 & 565 & 396 \\
\hline 5. Below South Fork & 8,310 & 1,283 & 588 \\
\hline 6. Steese Highway Bridge & 10,800 & 2,070 & 578 \\
\hline
\end{tabular}




\section{Chapter 5. Flow Recommendations}

Previous sections of this report have identified critical recreation, fishery and riparian resource values and established relationships between those values and instream flows. A brief summary of critical values and the streamflow needed to provide them are presented below and in Table 17 . These recommended streamflows have been rounded off for simplicity. Timing required for these streamflow needs is presented as well.

In making these recommendations, the underlying assumption is that any water not specifically reserved for instream flow resource values may eventually be removed from the river. Accordingly, if there is any doubt about a streamflow need, the monthly mean flow or the amount that nature would typically provide is recommended.

\section{Providing Recreation Opportunities}

There are essentially three types of recreation streamflow conditions on Birch Creek:
- Higher streamflow optimum floatability and whitewater conditions.

- Medium streamflow optimum floatability conditions.

- Lower streamflow marginal floatability conditions.

In a normal year, each of these occur for a portion of the season. While many recreation users might prefer optimum floatability and whitewater streamflow throughout the summer (May through September), most also recognize that the natural streamflow regime does not always provide optimum recreation and they seem willing to plan trips around the vagaries of the season. Accordingly, recommended streamflows for recreation are tempered by the actual streamflow we expect under the natural regime. Streamflows in the middle of the optimum range are recommended during the typical high flow month (May), while streamflows on the low

Table 17. Summary of important resource values and recommended flow needs for Birch Creek (discharge in cfs).

\begin{tabular}{|c|c|c|c|c|c|c|c|}
\hline Resource Valve & Timing & Seg. 1 & Seg. 2 & $\operatorname{Seg} \cdot 3$ & $\operatorname{Seg} \cdot 4$ & Seg. 5 & $\operatorname{Seg} .6$ \\
\hline $\begin{array}{l}\text { Optimum floatability and } \\
\text { whitewater recreation }\end{array}$ & $\begin{array}{l}\text { May- } \\
\text { Early June }\end{array}$ & na & 650 & 1,200 & 1,800 & 2,000 & 2,000 \\
\hline Optimum floatability recreation & June-July & na & 250 & 400 & 600 & 600 & 400 \\
\hline Marginal floatability recreation & Aug-Sept & na & 130 & 200 & 400 & 400 & 350 \\
\hline Grayling winter habitat & Dec-March & 1 & 2 & 2 & 5 & 8 & 15 \\
\hline Grayling migration habitat & April \& Oct-Nov & 15 & 25 & 40 & 80 & 120 & 200 \\
\hline Groyling summer habitat & July-Sept & 45 & 80 & 200 & 300 & 400 & 500 \\
\hline Grayling early summer habitat & May-June & 130 & 220 & 450 & 800 & 1,500 & 2,500 \\
\hline $\begin{array}{l}\text { Channel maintenance for riparian } \\
\text { vegetation and aquatic habitat }\end{array}$ & \begin{tabular}{|c|}
$\begin{array}{c}\text { One day between } \\
\text { Apr-June }\end{array}$ \\
\end{tabular} & 800 & 1,400 & 2,900 & 5,300 & 8,300 & 10,700 \\
\hline $\begin{array}{l}\text { Minimum summer flow for } \\
\text { riparian vegetation suvival }\end{array}$ & $\begin{array}{l}\text { June: } \\
\text { July: } \\
\text { August: }\end{array}$ & $\begin{array}{r}80 \\
145 \\
45\end{array}$ & $\begin{array}{l}200 \\
100 \\
100\end{array}$ & $\begin{array}{l}380 \\
190 \\
190\end{array}$ & $\begin{array}{l}570 \\
400 \\
400\end{array}$ & $\begin{array}{r}1,300 \\
600 \\
600\end{array}$ & $\begin{array}{r}2,000 \\
600 \\
600\end{array}$ \\
\hline
\end{tabular}

*na $=$ not applicable 
end of the optimum floatability range are recommended as streamflow decreases through June and July. In the low flow months of August and September, recommended streamflows equate to marginal floatability conditions because higher flows are uncommon at that time.

In contrast to the fish habitat flow recommendations, recreation streamflow requirements are occasionally higher than the mean monthly streamflow at a station. This is because chance rain events do occur throughout the summer, and opportunistic recreation users will take advantage of them. While it is unlikely that future out-of-stream water users would be able to capture water from these events and thus affect recreation flows, recommended streamflow refers to those that recreation users would want if they were available.

\section{Maintaining Fish and Aquatic Habitat}

Protection of the grayling and other fisheries requires streamflow sufficient to provide certain depths and wetted perimeters for various life stages during different times of the year. The critical life stages and time periods are listed below:

- Winter habitat for survival from

December through March.

- Migration flows in April and from October to November.

- Early summer habitat in May and June.

- Normal summer habitat in July and August.

In the early summer breakup, streamflow is required to provide good spawning habitat as well as to clean the gravel beds for spawning and macroinvertebrate production throughout the year. This streamflow is estimated to be at least 25 percent of bankfull flow. During the main part of the summer, streamflow is required for basic survival and fry rearing. Recommended streamflows are selected from a range of values determined from wetted perimiter graphs in Figures 10 to 15, minimum depths in peripheral areas, and Tennant (1975) calculations. These values are listed in Table 14. In general, these recommendations are well below the monthly average flows.

During the winter months, almost all available streamflow (estimated at 90 percent of monthly average streamflows) is necessary to maintain riffle depths and velocities for grayling survival and passage. While some grayling apparently live in pockets of water encased in ice, most prefer reaches with moderate to low velocities. In April and then again in October and November, streamflow is needed to allow migration to and from winter habitat. These streamflow recommendations are also essentially equal to expected natural flow ( 90 percent of monthly averages), and are judged to provide sufficient passage across riffles.

\section{Maintaining Riparian and Channel Features}

Streamflows are needed to maintain channel form and function for aquatic and terrestrial habitat as well as for high quality recreation. These streamflows are a starting point for maintaining the natural integrity of the river channel and its features. Based on professional judgment and literature reviews, two types of channel and riparian vegetation streamflow is required:

- A channel maintenance streamflow equal to the bankfull level for at least one day annually.

- Minimum summer streamflow to maintain riparian vegetation survival during low flow times.

The channel maintenance streamflow not only cleans the gravels used by fish and macroinvertebrates that fish eat, it also maintains the sloughs, pools, runs and riffles that provide cove and other kinds of habitat required during various fish life stages. The minimum summer streamflow simply ensures that existing vegetation does not wither during droughts. The BLM recognizes that instream flow water rights are not easily developed for channel maintenance streamflow because the timing and extent are more unknown and unpredictable. However, these higher streamflows are crucial for maintaining various features of the river environment, which are important components of the river's values. By including them in the recommendations, The BLM is explicitly recognizing their importance and 
suggesting that any human modifications to the streamflow regime ensure that these types of floods are provided for.

\section{Integrating Streamflow Needs: Recommended Hydrographs}

Integrating the variety of streamflow needs for different resource values requires an examination of timing issues and assessing trade-offs between streamflow needs. The result is a recommended hydrograph representing streamflow needs for the river. Recommended monthly streamflow for the six hydrological segments on Birch Creek are given in Table 18 and Figures 16 through 21. These figures also give the monthly mean streamflow for each segment for comparative purposes.

A single "decision-rule" formed the foundation for these recommended hydrographs: Whenever two streamflows are in competition, the higher is recommended so that both streamflow needs are met. Assuming that Birch Creek will never be regulated in such a way that significant streamflow would be added to the river, there is no case when naturally occurring higher streamflow that help one resource would negatively impact another.

These streamflow recommendations should be viewed as best estimates based on available hydrologic data and accumulated information collected for this assessment. As more hydrologic data is obtained, or new data about fisheries, riparian or recreation needs are acquired, these recommendations may need to be modified.

Table 18. Recommended streamflows by month for the six segments for Birch Creek (discharge in cfs).

\begin{tabular}{l|c|c|c|c|c|c}
\hline \hline Month & Segment 1 & Segment 2 & Segment 3 & Segment 4 & Segment 5 & Segment 6 \\
\hline January & 1 & 2 & 2 & 5 & 8 & 15 \\
\hline February & 1 & 2 & 2 & 5 & 8 & 15 \\
\hline March & 1 & 2 & 2 & 5 & 8 & 15 \\
\hline April & 15 & 25 & 40 & 80 & 120 & 200 \\
\hline May & 180 & 300 & 400 & 800 & 2,000 & 2,000 \\
\hline June & 130 & 250 & 400 & 800 & 1,500 & 2,000 \\
\hline July & 45 & 130 & 200 & 400 & 600 & 500 \\
\hline August & 45 & 130 & 200 & 400 & 600 & 500 \\
\hline September & 45 & 130 & 200 & 400 & 600 & 500 \\
\hline October & 15 & 25 & 40 & 80 & 120 & 200 \\
\hline November & 10 & 25 & 40 & 80 & 120 & 200 \\
\hline December & 1 & 2 & 2 & 5 & 8 & 15 \\
\hline I day/year & 800 & 1,400 & 2,900 & 5,300 & 8,300 & 10,800 \\
\hline \hline
\end{tabular}




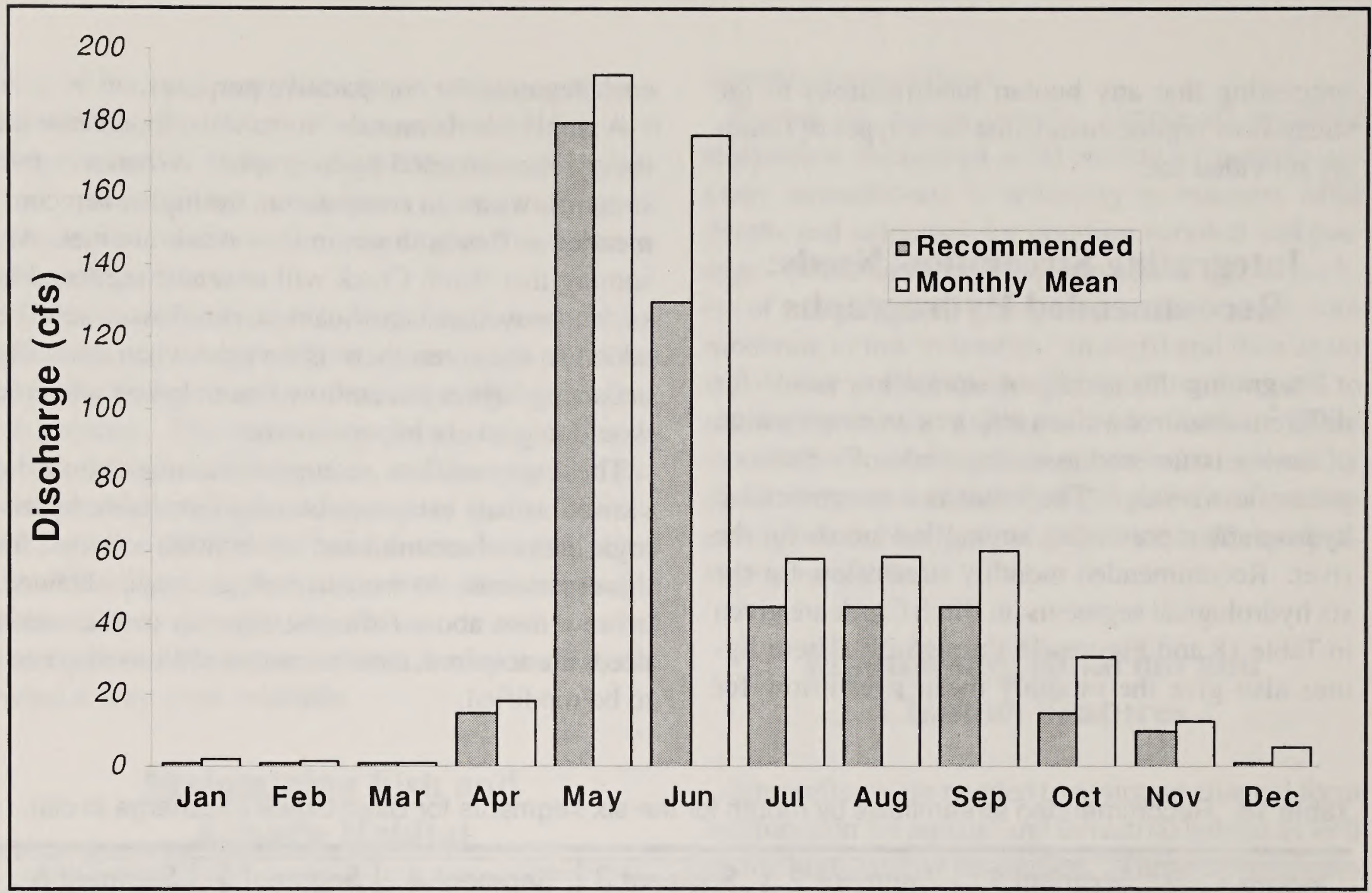

Figure 16. Monthly mean and recommended streamflow for Birch Creek above Twelvemile Creek (Segment 1).

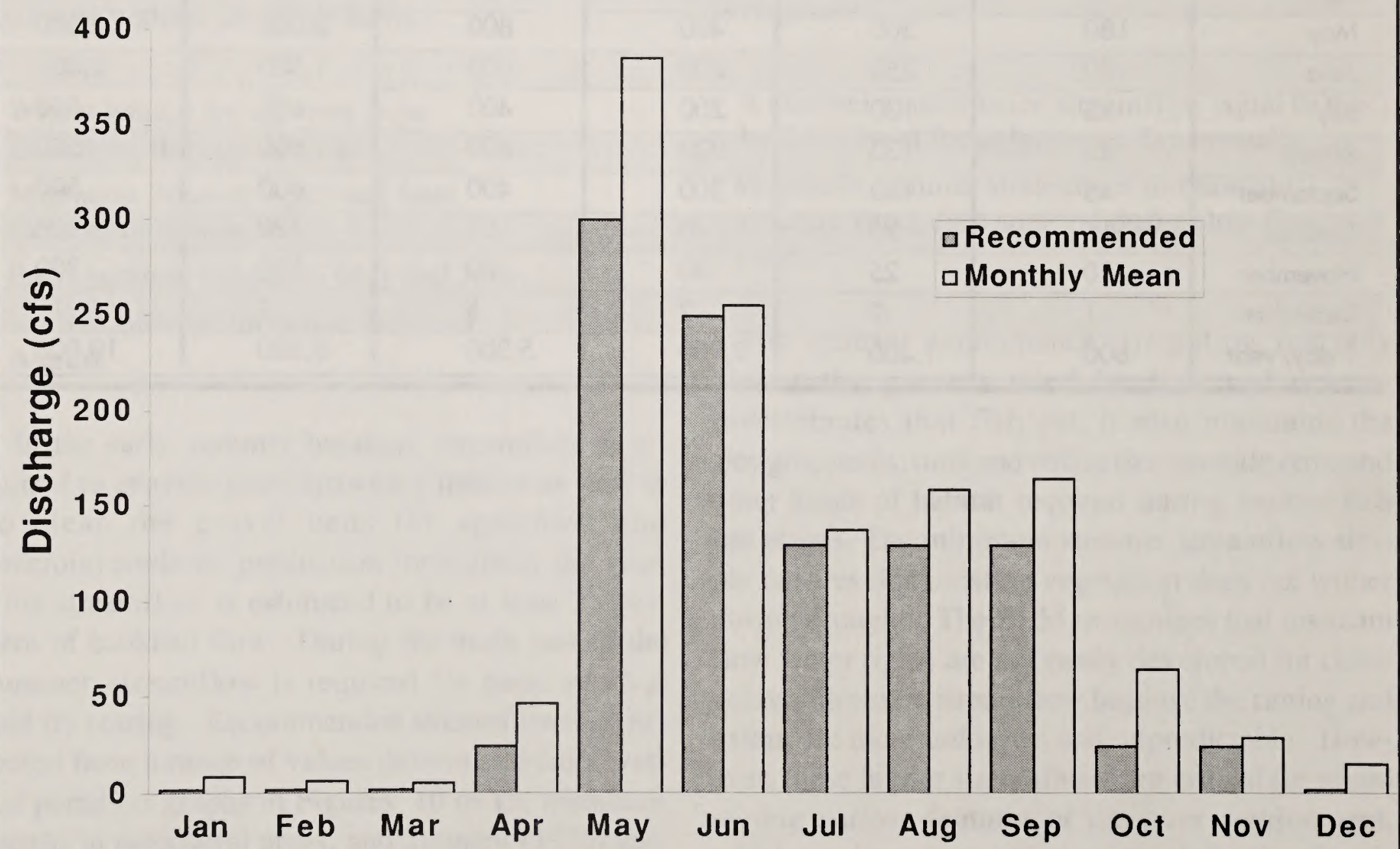

Figure 17. Monthly mean and recommended streamflow for Birch Creek below Twelvemile Creek (Segment 2). 


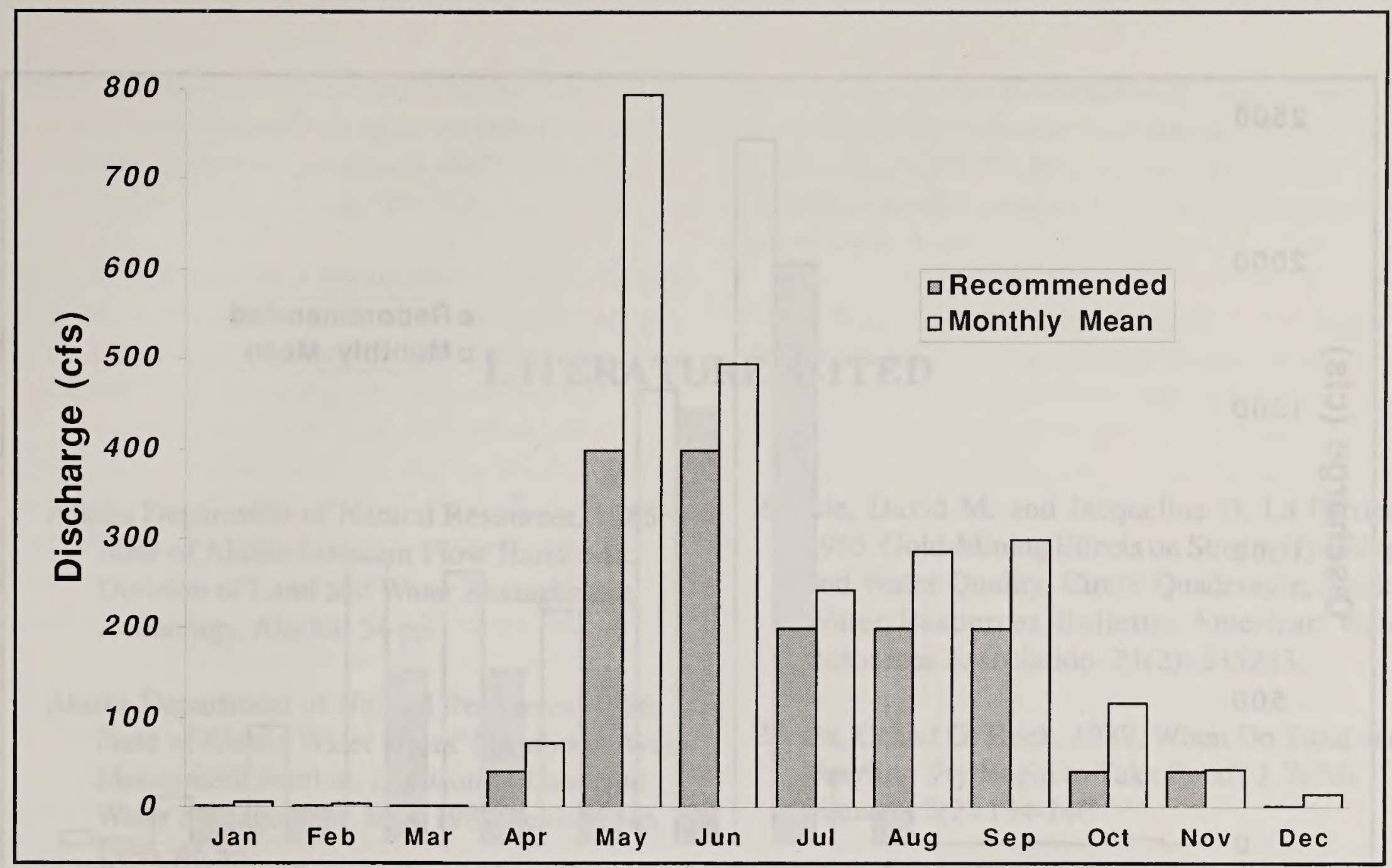

Figure 18. Monthly mean and recommended streamflow for Birch Creek above Clums Fork (Segment 3).

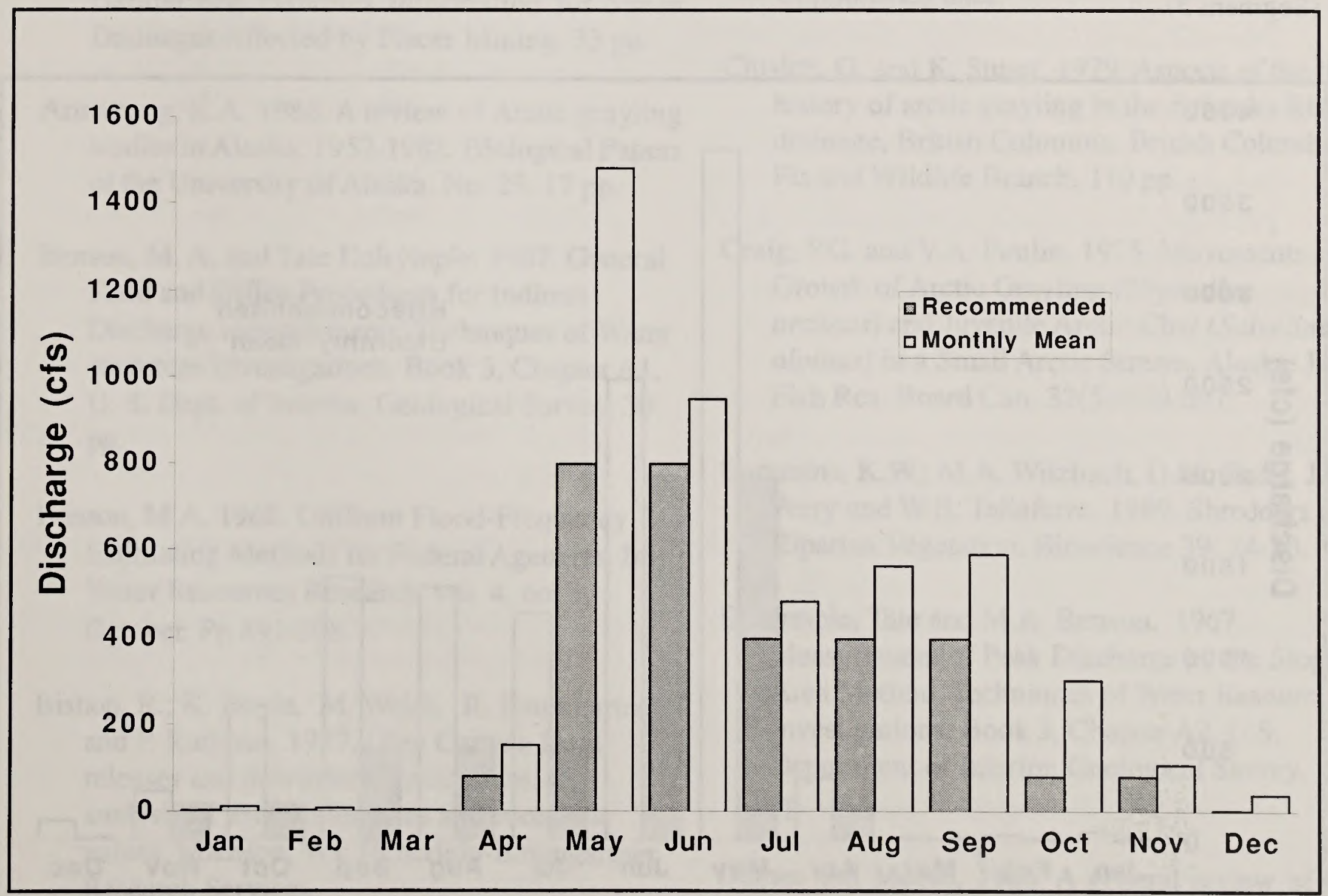

Figure 19. Monthly mean and recommended streamflow for Birch Creek below Harrison Creek (Segment 4). 


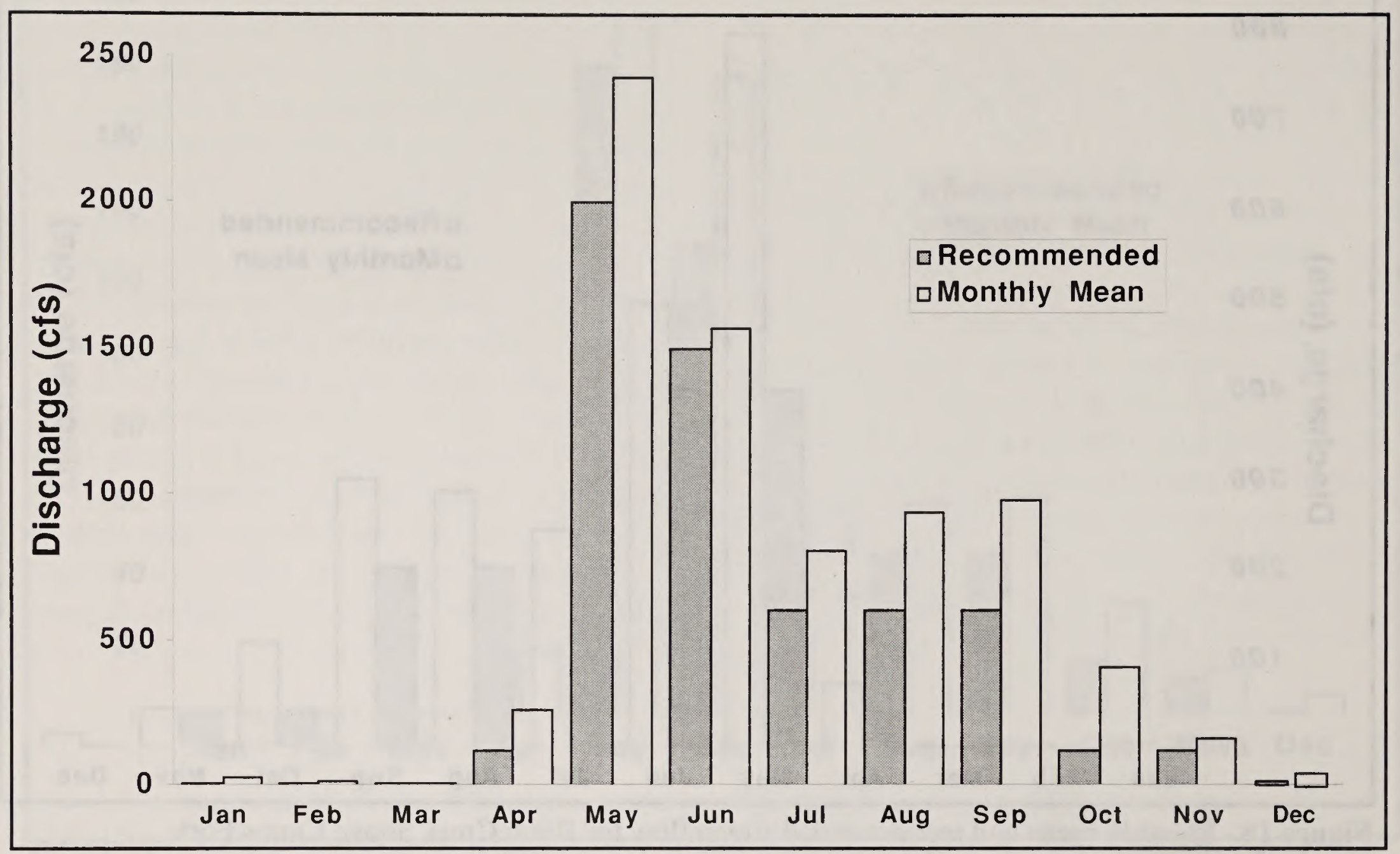

Figure 20. Monthly mean and recommended streamflow for Birch Creek below South Fork (Segment 5).

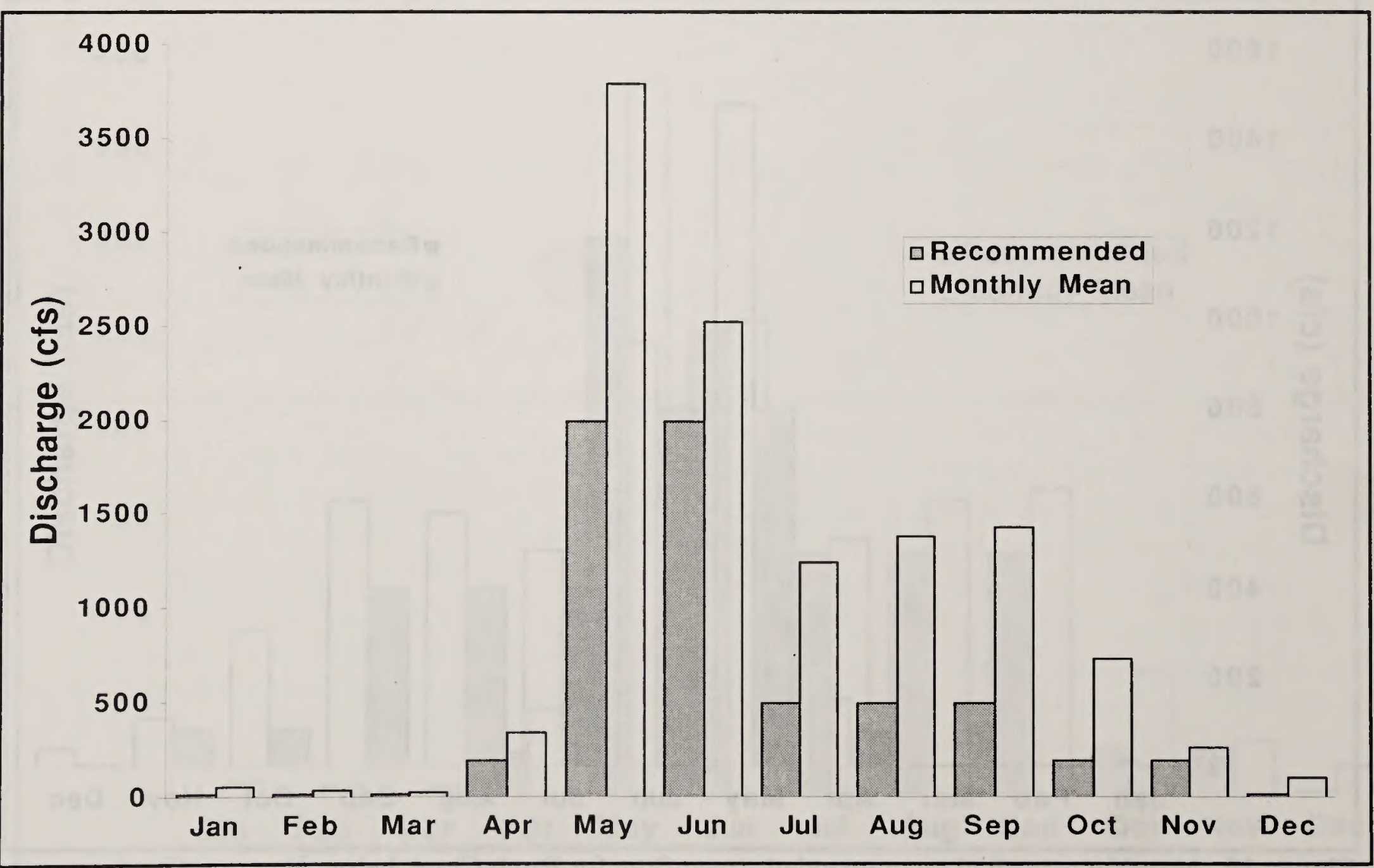

Figure 21. Monthly mean and recommended streamflow for Birch Creek at Steese Highway Bridge (Segment 6). 


\section{Literature Cited}

Alaska Department of Natural Resources. 1985. State of Alaska Instream Flow Handbook. Division of Land and Water Management, Anchorage, Alaska. 54 pp.

Alaska Department of Natural Resources. 1986. State of Alaska Water Users' Handbook. Water Managment Section, Division of Land and Water Management. May 1981; revised Jan. 1986. $46 \mathrm{pp}$.

Alaska Department of Fish and Game. 1987. Aquatic Habitat and Fisheries Information for Seven Drainages Affected by Placer Mining. 33 pp.

Armstrong, R.A. 1986. A review of Arctic grayling studies in Alaska, 1952-1982. Biological Papers of the University of Alaska. No. 23. 17 pp.

Benson, M. A. and Tate Dalrymple. 1967. General Field and Office Procedures for Indirect Discharge measurements. Techniques of Water resources Investigations. Book 3, Chapter A 1 , U. S. Dept. of Interior, Geological Survey. 30 pp.

Benson, M.A. 1968. Uniform Flood-Frequency Estimating Methods for Federal Agencies. In: Water Resources Research, vol. 4, no. 5, October. Pp 891-908.

Bishop, R.; K. Boyle, M. Welsh, R. Baumgartner, and P. Rathbun. 1987. Glen Canyon Dam releases and downstream recreation: an analysis of user preferences and economic values. Madison, WI: Heberlein-Baumgartner Research Services.
Bjerkle, David M. and Jacqueline D. La Perriere. 1985. Gold-Mining Effects on Stream Hydrology and Water Quality, Circle Quadrangle, Alaska. Water Resources Bulletin, American Water Resources Association. 21(2): 235243.

Brown, C. and G. Buck. 1939. When Do Trout and Grayling Fry Begin to Take Food? J. Wildl. Manage. 3(2):134-140.

Burkholder, A.R. and N.F. Hughes. 1989. University of Alaska Fairbanks, Fairbanks, Alaska. Unpublished data.

Chislett, G. and K. Stuart. 1979. Aspects of the life history of arctic grayling in the Sekunka River drainage, British Columbia. British Columbia Fis and Wildlife Branch. 110 pp.

Craig, P.G. and V.A. Poulin. 1975. Movements and Growth of Arctic Grayling (Thymallus arcticus) and Juvenile Arctic Char (Salvelinus alpinus) in a Small Arctic Stream, Alaska. J. Fish Res. Board Can. 32(5):689-697.

Cummins, K.W.; M.A. Wilzbach, D.M. Gates, J.B. Perry and W.B. Taliaferro. 1989. Shredders and Riparian Vegetation. Bioscience 39: 24-30.

Dalrymple, Tate and M.A. Benson, 1967. Measurement of Peak Discharge by the SlopeArea Method. Techniques of Water Resources Investigations, Book 3, Chapter A2, U.S. Department of Interior, Geological Survey. 12 pp.

Dames and Moore. 1986. A general review of the 
effects of gold placer mining including site specific reviews of selected subarctic Alaskan river basins. Prepared for: USDI, Bureau of Land Management, Alaska State Office, Anchorage, AK.

Elliott, G.V. 1980. First interim report on the evaluation of stream crossings and effects of channel modifications on fishery resources along the routes of the trans-Alaska pipeline. US Fish and Wildlife Service, Special Study, 1011 E. Tudor Road, Anchorage, AK. 77 pp.

Emmett, William W. 1972. The Hydraulic Geometry of Some Alaskan Streams South of the Yukon River. Open-file Report. U.S. Department of Interior, Geological Survey, Water Resources Division-Alaska District. 102 pp.

Fogg, J.L.; B.L. Henry, H.T. Mottl, D.P. Muller, R.C. Eaton and S. Swanson. 1992. Rio Chama Instream Flow Assessment. U.S. Department of the Interior-Bureau of Land Management, Denver Service Center. 75 pp. plus appendices.

Gammon, J.R. 1990. Fish Communities and Turbidity of Birch Creek, Alaska and its Tributaries in late July and early August 1990. DePauw Univ., Greencastle, Indiana. 17 pp.

Heede, R.D. 1976. Stream dynamics: an overview for land managers. USDA Forest Service General Technical Report RM-72. 26 pp.

Hill, M.T.; W.S. Platts and R.L. Beschta 1991. Ecological and Geomorphological Concepts for Instream and Out-of-Channel Flow Requirements. Rivers 2(3):198-210.

Hirsch, M. H.; J.F. Walker, J.C. Day and R. Kallio. 1990. The influence of man on hydrologic systems. Pp 329-359. In: Wolman, M. G. and H. C. Riggs, ed. Surface Water Hydrology. The Geology of North America; v. O-1. The Geological Society of America. 374 pp.
Holmes, R.A. 1981. Angler effort, exploitation and values on the Upper Chena River, Alaska. Master's thesis, University of Alaska Fairbanks. Fairbanks, AK. 105 pp.

Hubert, W.A.; R.S. Helzner, L.A. Lee and P.C. Nelson. 1985. Habitat Suitability Index Models and Instream Flow Suitability Curves: Arctic Grayling Riverine Populations. U.S. Fish and Wildl. Serv. Biol. Rep. 82(10.110). 34 pp.

Hughes, N.F. and L.M. Dill. 1990. Position choice by drift-feeding salmonids: model and test for arctic grayling in sub-arctic mountain streams in interior Alaska. Canadian Journal of Fishery and Aquatic Sciences 47: 2039-2048.

Hughes, N.F. and J.B. Reynolds. 1994. Why do Arctic Grayling (Thymallus arcticus) Get Bigger as You Go Upstream? Canadian Journal of Fishery and Aquatic Sciences 51:21542163.

Irons, III, J.G; J. P. Bryant and M.W. Oswood. 1991. Effects of Moose Browsing on Decomposition Rates of Litter in a Subarctic Stream. Can. J. Fish. Aquat. Sci. 48:442-444.

Jackson, W.L.; T. Martinez, P. Cuplin, W.L. Minkley, B. Shelby, P. Summers, D. McGlothlin and B. Van Haveren. 1987. Assessment of Water Conditions and Management Opportunities in Support of Riparian Values: BLM San Pedro River Properties, Arizona Project Completion Report. BLM Service Center, Denver, CO. 180 pp.

Jackson, W.L.; T. Martinez, B. Shelby and B.P. Van Haveren. 1989. An Interdisciplinary Process for Protecting Instream Flows. Journal of Soil and Water Conservation. 44(2): 121-126

Jones, S.H. and C.B. Fahl. 1994. Magnitude and Frequency of Floods in Alaska and Conterminous Basins of Canada. U.S. Geological Survey Water Resources Investigations Report 93-417g. 122 pp. 26. 
Juday, G.P; and J.C. Zasada. 1982. Structure and Development of an Oldgrowth White Spruce Forest on an Interior Alaskan Floodplain. Pp. 227-234.

Kostohrys, J. and B.G. Sterin. 1996. Water resources of Birch Creek National Wild River, Alaska. BLM data report. BLM Alaska State Office, Anchorage.

Kretsinger, C. 1986. Arctic Grayling Habitat Utilization Study on Seven Clearwater Streams Within the Birch Creek Watershed. U.S. Bureau of Land Management, Fairbanks, Alaska. Inhouse unpublished report, 13 pp.

Krueger, S.W. 1981. Fresh water Habitat Relationships: Arctic Grayling, Thymallus arcticus (Pallas), with Observations on Mating Success. J. Fish. Biol. 17:661-666.

Kruse, T. 1959. Grayling of Grebe Lake. Yellowstone National Park, WY. U.S. Fish and Wildl. Serv., Fish. Bull. 149. 59:305-351.

Lee, Kristine M. 1985. Resource partitioning and behavioral interactions among young-of-theyear salmonids, Chena River, Alaska. Master's Thesis. University of Alaska Fairbanks, Fairbanks, AK

Leopold, L.B. and H.E. Skibitzke. 1967. Observations on Unmeasured Rivers. Geogr. Ann. v. 49A, pp 247-255.

Liknes, G.A. 1981. The Fluvial Arctic Grayling (Thymallus arcticus) of the Upper Big Hole River Drainage, MT. Master's Thesis. Montana State Univ., Bozeman. 59 pp.

Lubinski, B.L. 1994. BLM, Steese/White Mountains District, Fairbanks, AK. Personal communication.

Lubinski, B.L. 1995. Winter habitat of arctic grayling in an interior Alaska stream. Master's thesis. University of Alaska Fairbanks, Fairbanks, AK
Madison, Robert J. 1981. Effects of Placer Mining on Hydrologic Systems in Alaska: Status of Knowledge. USDI, Bureau of Land Management, Anchorage, AK. BLM-Alaska Technical Report 7.32 pp.

Meehan, W.R.; T.R. Merrell, Jr., and T.A. Hanley, eds. 1984. Fish and wildlife relationships in old-growth forests: proceedings of a symposium held in Juneau, AK, 12-15 April 1982. Amer. Inst. Fish Res. Biol. 425 pp.

McLeay, D.J.; A.J. Knox, J.G. Malick, I.K. Birtwell, G. Hartmann and G.L. Ennis. 1983. Effects on arctic grayling of short-term exposure to Yukon placer mining sediments: Laboratory and field studies. Canadian Technical Report of Fisheries and Aquatic Sciences. No. 1171.

Mertie, J.B. 1937. The Yukon-Tanana Region, Alaska. Geological Survey Bulletin 872. U.S. Department of the Interior, Geological Survey. $276 \mathrm{pp}$.

Morisawa, Marie. 1968. Streams: their dynamics and morphology. New York, NY: McGraw-Hill Book Company. 175 pp.

Murphy, M.L. and K.V. Koski. 1989. Input and Depletion of Woody Debris in Alaska Streams and Implications for Streamside Management. N. Am. J. Fish. Manag. 9:427-436.

Morrow, James E. 1980. The Freshwater Fishes of Alaska. Alaska Northwest Publishing Company. Anchorage, AK. 248 p

Nelson, P.H. 1954. Life history and management of the American grayling (Thymallus signifer tricolor) in Montana. Journal of Wildlife Management. 18: 324-342.

Nelson, G.L. 1978. Hydrologic Information for Land-Use Planning: Fairbanks and Vicinity, Alaska. Open-File Report 78-959. U.S. Department of the Interior, Geological Survey. $47 \mathrm{pp}$. 
Parks, B. and R.J. Madison. 1985. Estimation of Selected Flow and Water Quality Characteristics of Alaskan Streams. WaterResources Investigations Report 84-4247. U.S. Department of the Interior, Geological Survey. $50 \mathrm{pp}$.

Parsons, S.C. and S. Hudson. 1985. Stream Channel Cross-Section Surveys and Data Analysis. U.S.D.I. BLM TR 4341-1, Denver, $\mathrm{CO}, 48 \mathrm{pp}$.

Pewe, T.L.; L. Burbank and L.R. Mayo. 1967. Multiple Glaciation in the Yukon-Tanana Upland, Alaska. USGS Misc. Geol. Inv. Map I507, 1 sheet, scale 1:500,000. USDI, Geol. Surv.

Prewitt, C.G. and C.A. Carlson. 1977. Evaluation of four instream flow methodologies used on the Yampa and White Rivers, Colorado. Western Energy and Land Use Team. USDI, Fish and Wildlife Service, Office of Biological Services. $96 \mathrm{pp}$.

Ray, S.R. 1990. Hydrologic and Water Quality Investigations Related to Placer Mining in Interior Alaska; Summer 1989. Public-data File 90-28. Alaska Dept. Of Natural Resources, Div. Of Geological and Geophysical Surveys. Fairbanks, AK. 58 pp.

Ray, S. R. 1991. Hydrologic and Water Quality Investigations Related to Placer Mining in Interior Alaska: Summer 1990. Public-data File 91-19. Alaska Department of Natural Resources, Division of Geological and Geophysical Surveys. Fairbanks, AK. 60 pp.

Ray, S.R. 1992. Hydrologic and Water Quality Investigations Related to Placer Mining in Interior Alaska; Summer 1991. Public-data File. Alaska Dept. Of Natural Resources, Div. Of Geological and Geophysical Surveys. Fairbanks, AK. 73 pp.
Ray, S.R. 1993. Hydrologic and Water Quality Investigations Related to Placer Mining in Interior Alaska; Summer 1992. Public -data File 93-46. Alaska Dept. Of Natural Resources, Div. Of Geological and Geophysical Surveys. Fairbanks, AK. 83 pp.

Rantz, S.E. and others. 1982. Measurement and Computation of Streamflow. Vols. 1 and 2. Computation of Discharge. USGS WaterSupply Paper 2175. USDI, Geol. Surv. 631 pp.

Reed, R.J. 1964. Life History and Migration Patterns of Arctic Grayling, Thymallus arcticus (Pallas), in the Tanana River Drainage of Alaska. Alaska Dept. Fish and Game. Res. Rep. 2. Fairbanks, AK. 30 pp.

Reynolds, J.B.; R.C. Simmons and A.R. Burkholder. 1989. Effects of Placer Mining Discharge on Health and Food of Arctic Grayling. Water Res. Bull. Vol. 25. No. 3:625635.

Reynolds, J.B. 1989. Evaluation of the HSI model for riverine Arctic grayling in relation to Alaskan Project Impacts. Unit Contribution No. 32. Alaska Cooperative Fisheries Research Unit, University of Alaska Fairbanks. Fairbanks, AK. $23 \mathrm{pp}$.

Rogers, J.D. and J.T. Armbruster,1990. Low flows and hydrologic droughts. In: Wolman, M.G. and Riggs, H.C., ed.; Surface Water Hydrology. The Geology of North America. vol. O-1. The Geology Society of America. 374 pp.

Shelby, Bo; Bruce P. VanHaveren, William Jackson, Doug Whittaker, Don Prichard, and Dave Ellerbrook. 1990. Resource Values and Instream Flow Reccommendations, Gulkana National Wild River, Alaska. USDI BLM Service Center, Denver, CO. 76pp. 
Shelby, Bo; T.C. Brown and J.G. Taylor.

Streamflow and Recreation. Jan. 1992.

U.S.D.A. Forest Service. General Technical Report RM-209. 27 pp.

Tack, S.L. 1970. Distribution, abundance, and natural history of the arctic grayling in the Tanana River drainage. Alaska Department of Fish and Game. Federal Aid in Fish Restoration. Annual Report of Progress Project, 1970-1971. F-9-3, 12(R-I). $35 \mathrm{pp}$.

Tack, S.L. 1974. Distribution, abundance, and natural history of the arctic grayling in the Tanana River drainage. Alaska Department of Fish and Game. Federal Aid in Fish Restoration. Annual Report of Progress, 19731974, Project F-9-6, 15 (R-1). 52 pp.

Tennant, D.L. 1975. Instream Flow Regimes for Fish, Wildlife, Recreation and Related Environmental Resources. U.S. Fish and Wildlife Service. Billings, MT.

U.S. Department of Commerce, Weather Bureau. 1963. Probable Maximum Precipitation and Rainfall Frequency Data for Alaska. Technical Paper No. 47. 69 pp.

USDI, Alaska Planning Group. 1975. Final Environmental Statement, Proposed Birch Creek National Wild River, Alaska. 404 pp.

USDI, Bureau of Land Management, Alaska State Office. 1988. Final Cumulative Environmental Impact Statement, Birch Creek Placer Mining, Alaska. 400 pages.

USDI, Bureau of Outdoor Recreation. Prepared by Alaska Planning Group, Washington, D.C. Dec. 1973. Birch Creek National Wild River, Alaska, A Study. 39 pp.

USDI, Bureau of Outdoor Recreation. Prepared by Alaska Planning Group, Washington, D.C. 1973. Department of the Interior, Draft Environmental Statement, Proposed Inclusion of Birch Creek into the National Wild and Scenic Rivers System. 94 pp.
USDI, Bureau of Land Management, Fairbanks District, Alaska. 1983. River Management Plan for the Birch Creek National Wild River, Alaska. 56 pp.

USDI, Geological Survey. 1990-1995. Water Resources Data for Alaska, Water Years 19891994. Water Resources Division. Anchorage, AK.

USDI, Geological Survey, 1915. Ellsworth, C.E. and Davenport, R.W. Surface Water Supply of the Yukon-Tanana Region, Alaska. Water Supply Paper 342. 156 pp.

Van Haveren, B.P.; W.L. Jackson, T. Martinez, B. Shelby and L. Carufel. 1987. Water Rights Assessment for Beaver Creek National Wild River: Alaska. BLM Service Center, Denver, CO. 113 pp.

Vandas, S.; D. Whittaker, D. Murphy, D. Pritchard, L. MacDonnell, B. Shelby, D. Muller, J. Fogg, B. Van Havern, 1990. Dolores River Instream Flow Assessment. U.S. Department of the Interior-Bureau of Land Management, Denver Service Center. 92 pp. plus appendices.

Van Cleve, K.; T. Dyrness and L. Viereck. 1980. Nutrient Cycling in Interior Alaska Floodplains and its Relationship to Regeneration and Subsequent Forest Development. Pp. 11-18, In Murray, M. and R.M. Van Vedhuizen, eds.. 1980. Forest Regeneration at High Latitudes. Proc. of an International Workshop, Nov. 1517, 1979. (Fairbanks, AK) USDA For. Serv. Gen. Tech. Rpt. PNW-107.

Van Cleve, K.; F.S. Chapin III, P.W. Flanagan, L.A. Viereck and C.T. Dyrness, eds. 1986. Forest Ecosystems in the Alaskan Taiga. SpringerVerlag, N.Y., N.Y. 225 pp.

Vascotto, G.L. and J.E. Marrow. 1973. Behavior of the Arctic Grayling, Thymallus arcticus, in McManus Creek, Alaska. Biol. Pap. 13:29-38. Univ. Alaska, Dept. Biol. Sci., Anchorage. 
Viereck, L.A. 1970. Forest Succession and Soil Development Adjacent to the Chena River in Interior Alaska. Arctic and Alpine Res. 2:1-26.

Viereck, L.A.; K.Van Cleve, P.C. Adams and R.E. Schlentner. 1993. Climate of the Tanana River floodplain near Fairbanks, Alaska. Canadian Journal of Forest Resources 23: 899-913.

Vincent, R.E. 1962. Biogeographical and Ecological Factors Contributing to the Decline of Arctic Grayling, Thymallus arcticus pallas, in Michigan and Montana. Ph.D. Thesis, Univ. of Michigan, Ann Arbor. 169 pp.

Vogler, D. and J. Webb. 1984. Unpublished trip report. Bureau of Land Management. Fairbanks, Alaska.

Vohden, J. 1994. Unpublished data. Alaska Div. Of Mining and Water. Fairbanks, AK.

Warner, G. 1955. Spawning Habitat of Grayling in Interior Alaska. U.S. Fish and Wildl. Serv. Fed. Aid in Fish Restoration, Q. Prog. Rep. (F-1-R5). $10 \mathrm{pp}$.

Weagle, K. 1980. Report on the Technical Workshop.on Suspended Solids and Aquatic Environment. Department of Indian Affairs and Northern Development. Whitehorse, Y.T., Canada. 22 pp.

Webb, J. 1982-86. Unpublished trip reports. Bureau of Land Management, Fairbanks, Alaska.

Webb, J.F. 1977. Age and growth of Arctic Grayling (Thymallus arcticus) in Birch Creek, AK. USDI, Bureau of Land Management, Fairbanks, AK. Unpublished report. 22 pp.

Webb, J.F.; R. Post and C. Hemming. Fish and water quality inventory of unmined tributaries of Birch Creek with supplementary water quality data from mined streams. Unpublished report. Fairbanks, AK.
Weber, P.; and R. Post. 1985. Aquatic Habitat Assessments in Mined and Unmined Portions of the Birch Creek Watershed. Technical Report No. 852. Alaska Dept. of Fish and Game. 65 pp.

Wedemeyer, G.A. and D.J. McLeay. 1981. Methods for determining the tolerance of fishes to environmental stressors. In Stress and Fish, pp 247-275. A.D. Pickering, ed. Academic Press, London.

Wedemeyer, G.A.; F.P. Meyer and L. Smith. 1976. Environmental stress and fish diseases. Book 5, pp 1-192. In Diseases of Fishes, S.F. Snieszeko \& H.R. Axelrod, eds. T.H.F. Publications Inc., New Jersey. 


\section{A PPENDIX A \\ Transect Plots and Streamflow Tables}

Figure 22 to Figure 27 and Table 19 to Table 24

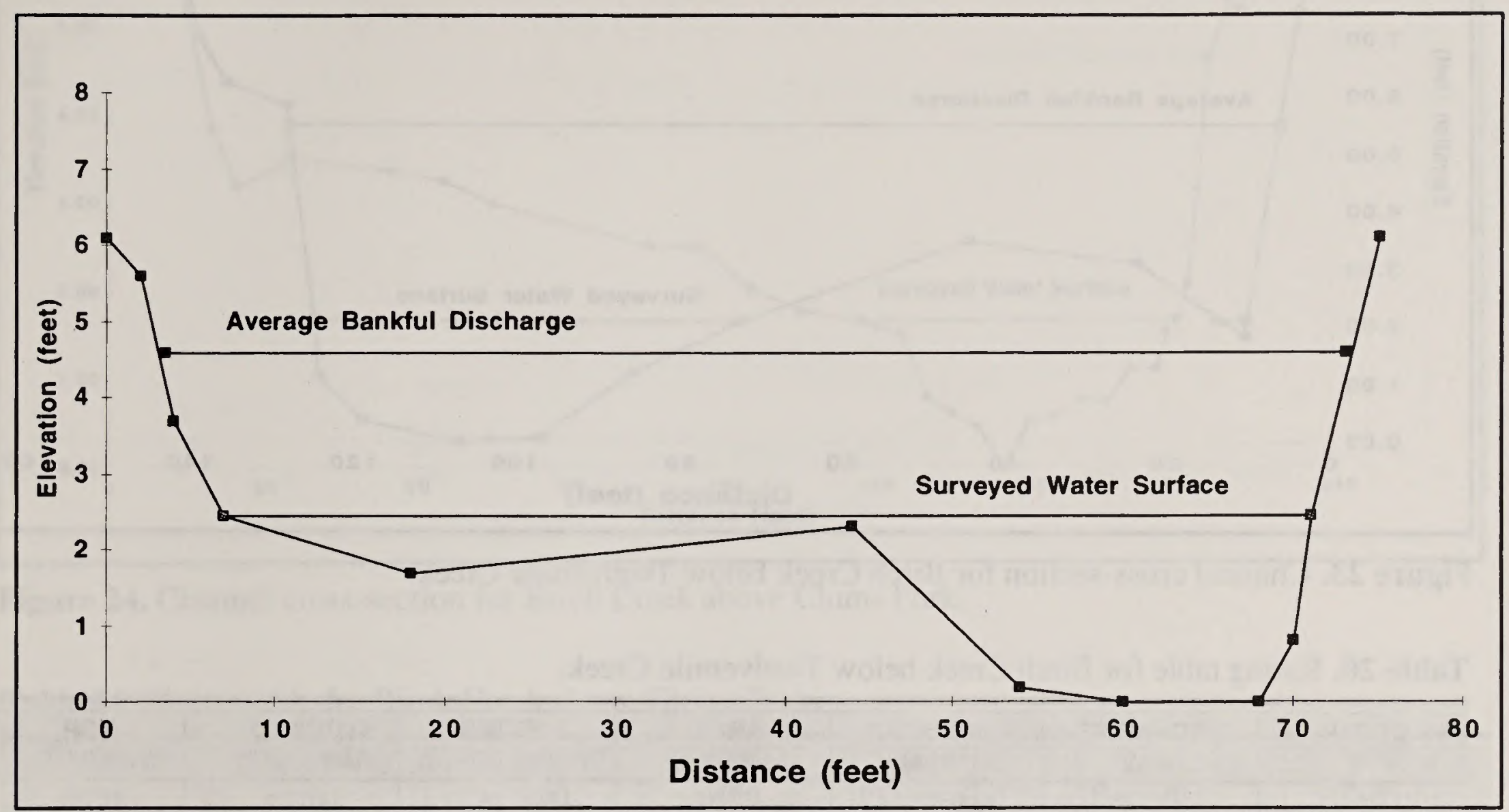

Figure 22. Channel cross-section for Birch Creek above Twelvemile Creek.

Table 19. Rating table for Birch Creek above Twelvemile Creek.

\begin{tabular}{|c|c|c|c|c|c|c|}
\hline : & 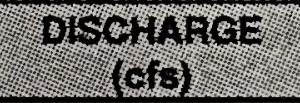 & 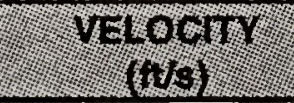 & :Un & PEDUETER W & 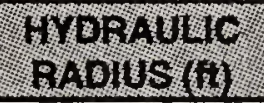 & ? \\
\hline 0.4 & 2.0 & 0.30 & 5 & 16 & 0.30 & 16 \\
\hline 0,8 & WI: & 0.57 & שn: & $19:$ & 0.60 & Win: \\
\hline 1.2 & 18 & 0.89 & 20 & 22 & 0.90 & 21 \\
\hline $12: 1,6$ & 34 & 12: & ? & 2, & 120 & ?: \\
\hline 2.0 & 46 & 1.11 & 41 & 44 & 0.90 & 43 \\
\hline 24 & 7.79 & 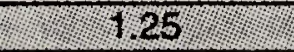 & 63 & 65 & 100 & 1: \\
\hline 2.8 & 150 & 1.68 & 89 & 67 & 1.30 & 65 \\
\hline 32 & 246 & 2.10 & w & 68 & 170 & 67. \\
\hline 3.6 & 371 & 2.60 & 142 & 70 & 2.00 & 68 \\
\hline 40 & 529 & 3.10 & 170 & WLi: & 2,40 & 69 \\
\hline 4.4 & 724 & 3.70 & 198 & 73 & 2.70 & 70 \\
\hline $1,4.8$ & 958 & 4.20 & : & 74 & 3.10 & 71 l: \\
\hline 5.2 & 1,236 & 4.90 & 254 & 75 & 3.40 & 72 \\
\hline 5.6 & 1,563 & 1. & Lif & 76 & 3.70 & 72 \\
\hline 6.0 & 1,930 & 6.20 & 312 & 78 & 4.00 & 75 \\
\hline
\end{tabular}




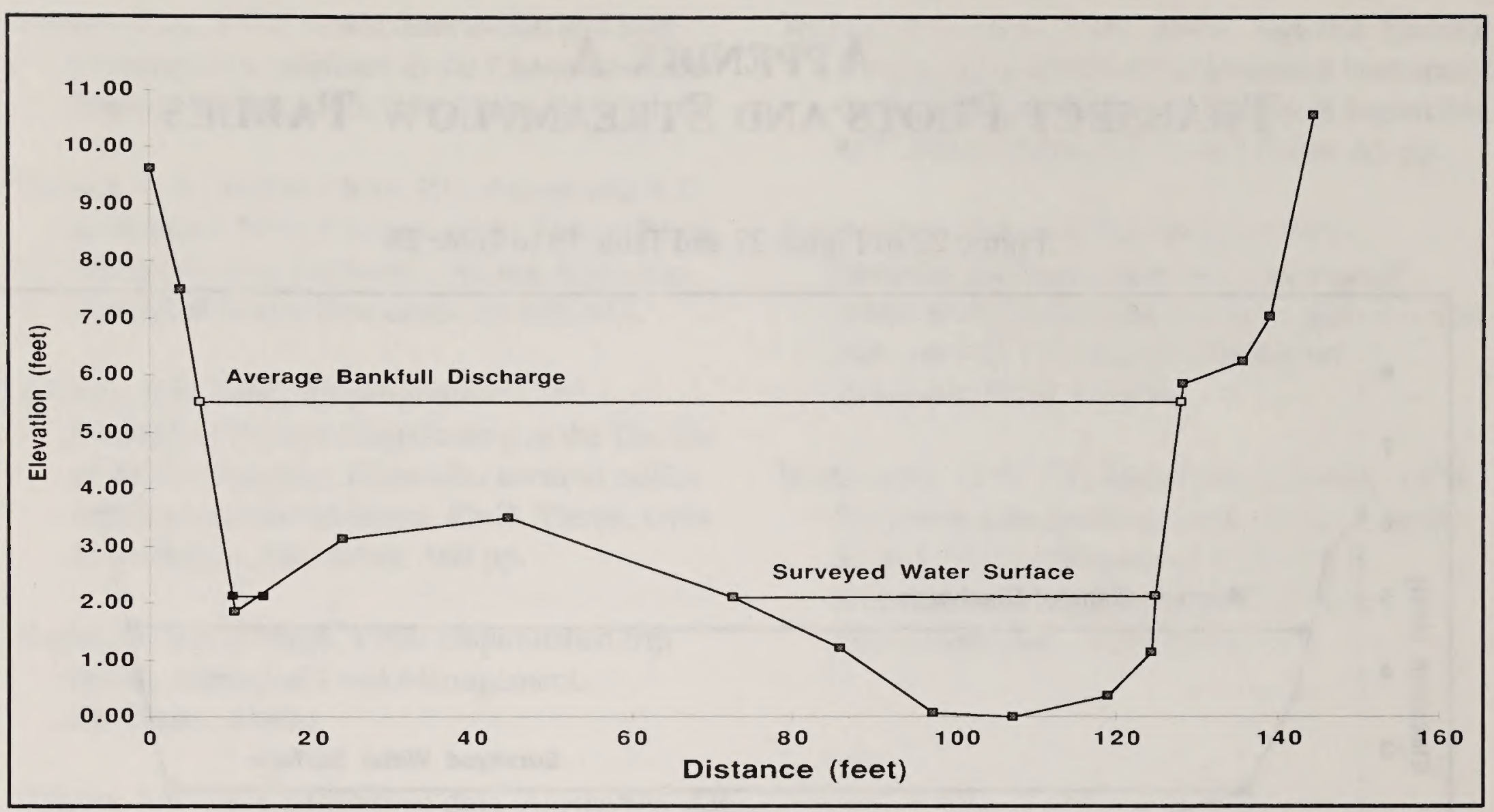

Figure 23. Channel cross-section for Birch Creek below Twelvemile Creek.

Table 20. Rating table for Birch Creek below Twelvemile Creek.

\begin{tabular}{c|c|c|c|c|c|c}
\hline $\begin{array}{c}\text { DEPTH } \\
(\mathrm{ft})\end{array}$ & $\begin{array}{c}\text { DISCHARGE } \\
(\mathbf{c f s})\end{array}$ & $\begin{array}{c}\text { VELOCITY } \\
(\mathrm{ft} / \mathbf{s})\end{array}$ & $\begin{array}{c}\text { AREA } \\
\left(\mathrm{ft}^{2}\right)\end{array}$ & $\begin{array}{c}\text { WETTED } \\
\text { PERIMETER }(\mathrm{ft})\end{array}$ & $\begin{array}{c}\text { HYDRAULIC } \\
\text { RADIUS (ft) }\end{array}$ & $\begin{array}{c}\text { TOP } \\
\text { WIDTH (ft) }\end{array}$ \\
\hline 1.0 & 5 & 0.42 & 12 & 36 & 0.34 & 36 \\
\hline 1.4 & 12 & 0.50 & 24 & 42 & 0.57 & 42 \\
\hline 1.9 & 28 & 0.69 & 41 & 49 & 0.83 & 49 \\
\hline 2.3 & 61 & 1.01 & 60 & 57 & 1.06 & 61 \\
\hline 2.7 & 132 & 1.51 & 87 & 66 & 1.31 & 75 \\
\hline 3.2 & 200 & 1.70 & 117 & 92 & 1.27 & 90 \\
\hline 3.6 & 303 & 1.98 & 153 & 120 & 1.28 & 118 \\
\hline 4.0 & 476 & 2.38 & 200 & 121 & 1.65 & 119 \\
\hline 4.5 & 701 & 2.79 & 252 & 122 & 2.05 & 120 \\
\hline 4.9 & 945 & 3.12 & 303 & 124 & 2.45 & 120 \\
\hline 5.3 & 1,253 & 3.53 & 355 & 125 & 2.84 & 121 \\
\hline 5.8 & 1,602 & 3.93 & 408 & 126 & 3.23 & 122 \\
\hline 6.2 & 1,976 & 4.29 & 460 & 133 & 3.45 & 129 \\
\hline 6.6 & 2,421 & 4.72 & 513 & 137 & 3.75 & 132 \\
\hline 7.5 & 3,597 & 5.80 & 620 & 141 & 4.40 & 136 \\
\hline
\end{tabular}




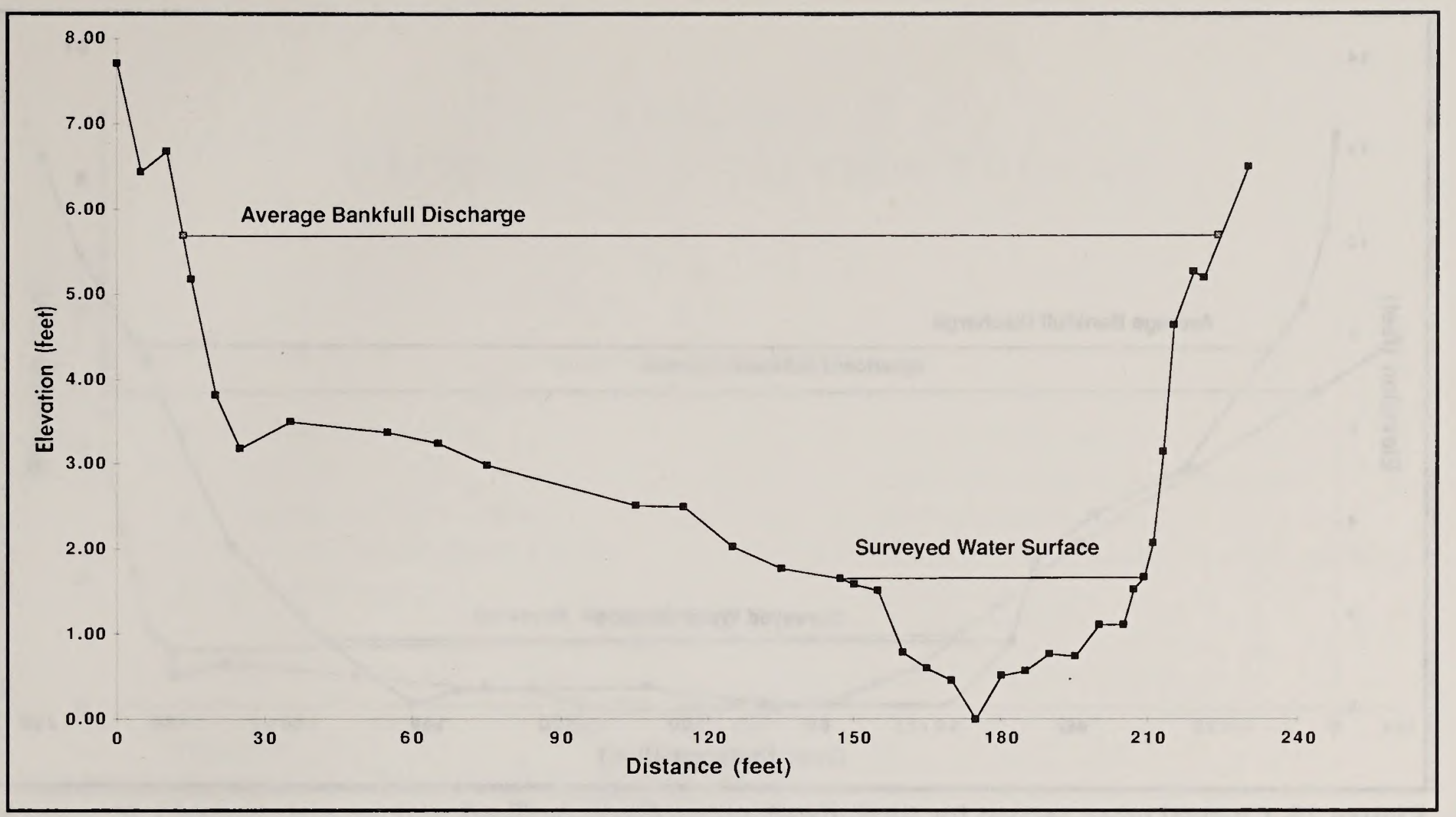

Figure 24. Channel cross-section for Birch Creek above Clums Fork.

Table 21. Rating table for Birch Creek above Clums Fork.

\begin{tabular}{|c|c|c|c|c|c|c|}
\hline $\begin{array}{l}\text { DEPTH } \\
\text { (ft) }\end{array}$ & $\begin{array}{l}\text { DISCHARGE } \\
\text { (cfs) }\end{array}$ & $\begin{array}{l}\text { VELOCITY } \\
\text { (ft/s) }\end{array}$ & $\begin{array}{c}\text { AREA } \\
\left(\mathrm{ft}^{2}\right)\end{array}$ & $\begin{array}{c}\text { WETTED } \\
\text { PERIMETER }(\mathrm{ft})\end{array}$ & $\begin{array}{l}\text { HYDRAULIC } \\
\text { RADIUS (ft) }\end{array}$ & $\begin{array}{c}\text { TOP } \\
\text { WIDTH (ft) }\end{array}$ \\
\hline 0.9 & 12 & 0.82 & 15 & 39 & 0.37 & 39 \\
\hline 1.3 & 40 & 1.22 & 33 & 49 & 0.67 & 49 \\
\hline 1.7 & 79 & 1.44 & 55 & 66 & 0.83 & 66 \\
\hline 2.1 & 143 & 1.67 & 86 & 85 & 1.01 & 85 \\
\hline 2.5 & 224 & 1.84 & 122 & 107 & 1.14 & 107 \\
\hline 2.9 & 344 & 2.03 & 170 & 132 & 1.28 & 132 \\
\hline 3.3 & 504 & 2.22 & 227 & 158 & 1.44 & 157 \\
\hline 3.7 & 711 & 2.38 & 299 & 194 & 1.55 & 193 \\
\hline 4.1 & 1,054 & 2.79 & 377 & 196 & 1.92 & 195 \\
\hline 4.5 & 1,459 & 3.20 & 456 & 198 & 2.30 & 197 \\
\hline 4.9 & 1,915 & 3.58 & 535 & 203 & 2.64 & 201 \\
\hline 5.3 & 2,425 & 3.93 & 617 & 208 & 2.97 & 207 \\
\hline 5.7 & 3,016 & 4.31 & 700 & 211 & 3.32 & 210 \\
\hline 6.1 & 3,685 & 4.70 & 784 & 213 & 3.68 & 211 \\
\hline 6.5 & 4,395 & 5.05 & 869 & 217 & 4.01 & 215 \\
\hline
\end{tabular}




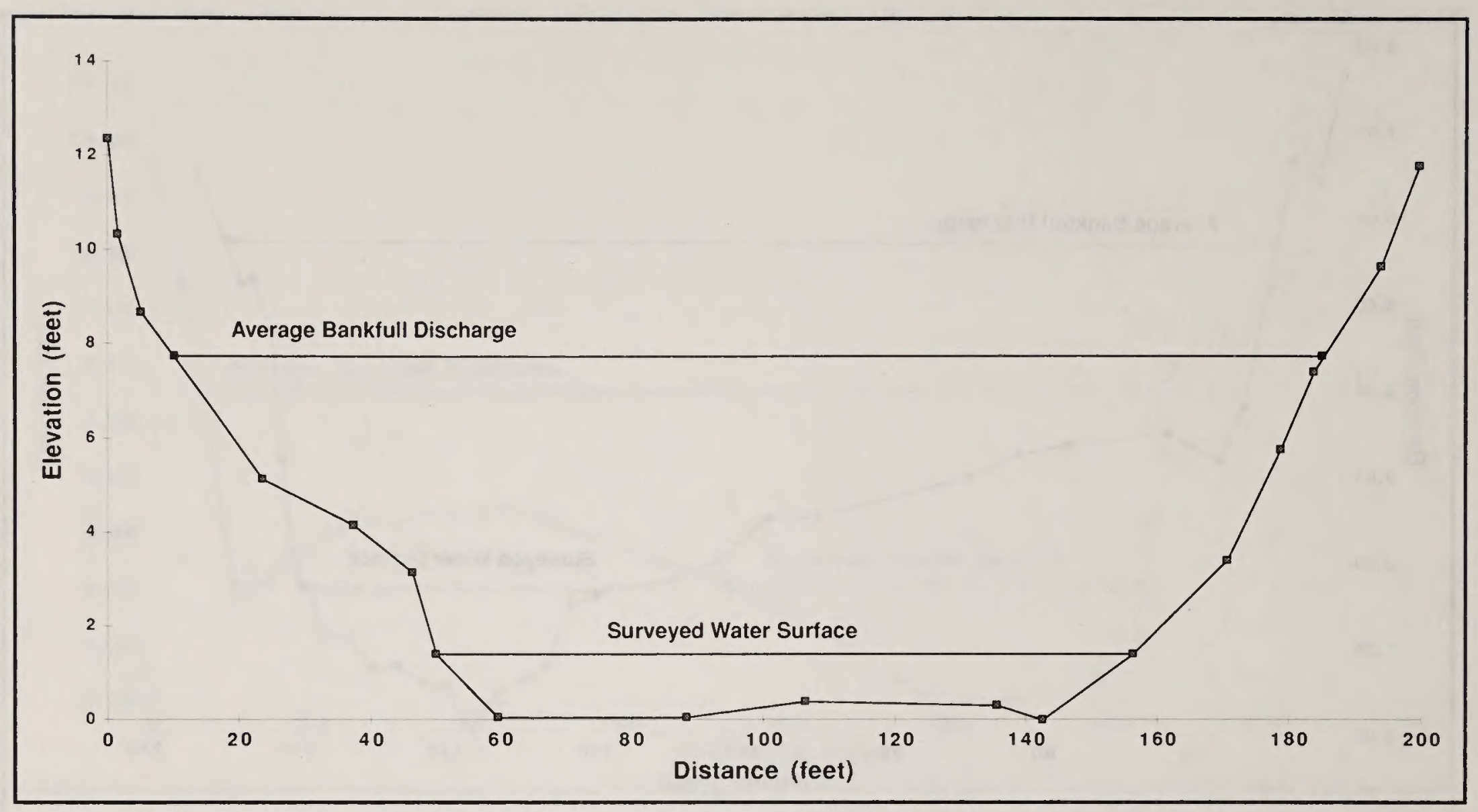

Figure 25. Channel cross-section for Birch Creek above Harrison Creek.

Table 22. Rating table for Birch Creek above Harrison Creek.

\begin{tabular}{|c|c|c|c|c|c|c|}
\hline $\begin{array}{l}\text { DEPTH } \\
\text { (ft) }\end{array}$ & $\begin{array}{l}\text { DISCHARGE } \\
\text { (cfs) }\end{array}$ & $\begin{array}{l}\text { VELOCITY } \\
(\mathrm{ft} / \mathrm{s})\end{array}$ & $\begin{array}{c}\text { AREA } \\
\left(\mathrm{ft}^{2}\right)\end{array}$ & \begin{tabular}{|c|} 
WETTED \\
PERIMETER $(\mathrm{ft})$
\end{tabular} & $\begin{array}{l}\text { HYDRAULIC } \\
\text { RADIUS (ft) }\end{array}$ & $\begin{array}{c}\text { TOP } \\
\text { WIDTH (ft) }\end{array}$ \\
\hline 0.6 & 30 & 0.8 & 38 & 93 & 0.4 & 93 \\
\hline 1.4 & 171 & 1.4 & 119 & 107 & 1.1 & 106 \\
\hline 2.2 & 437 & 2.1 & 208 & 114 & 1.8 & 114 \\
\hline 3.0 & 809 & 2.7 & 303 & 122 & 2.5 & 122 \\
\hline 3.8 & 1,283 & 3.2 & 405 & 133 & 3.1 & 132 \\
\hline 4.6 & 1,862 & 3.6 & 517 & 146 & 3.5 & 145 \\
\hline 5.4 & 2,570 & 4.0 & 639 & 157 & 4.1 & 156 \\
\hline 6.3 & 3,438 & 4.5 & 767 & 164 & 4.7 & 163 \\
\hline 7.1 & 4,437 & 4.9 & 901 & 171 & 5.3 & 169 \\
\hline 7.9 & 5,557 & 5.3 & 1,041 & 178 & 5.8 & 177 \\
\hline 8.7 & 6,838 & 5.8 & 1,186 & 186 & 6.4 & 184 \\
\hline 9.5 & 8,317 & 6.2 & 1,337 & 192 & 7.0 & 190 \\
\hline 10.3 & 9,957 & 6.7 & 1,492 & 196 & 7.6 & 194 \\
\hline 11.1 & 11,749 & 7.1 & 1,650 & 200 & 8.3 & 197 \\
\hline 11.9 & 13,487 & 7.5 & 1,810 & 203 & 8.9 & 199 \\
\hline
\end{tabular}




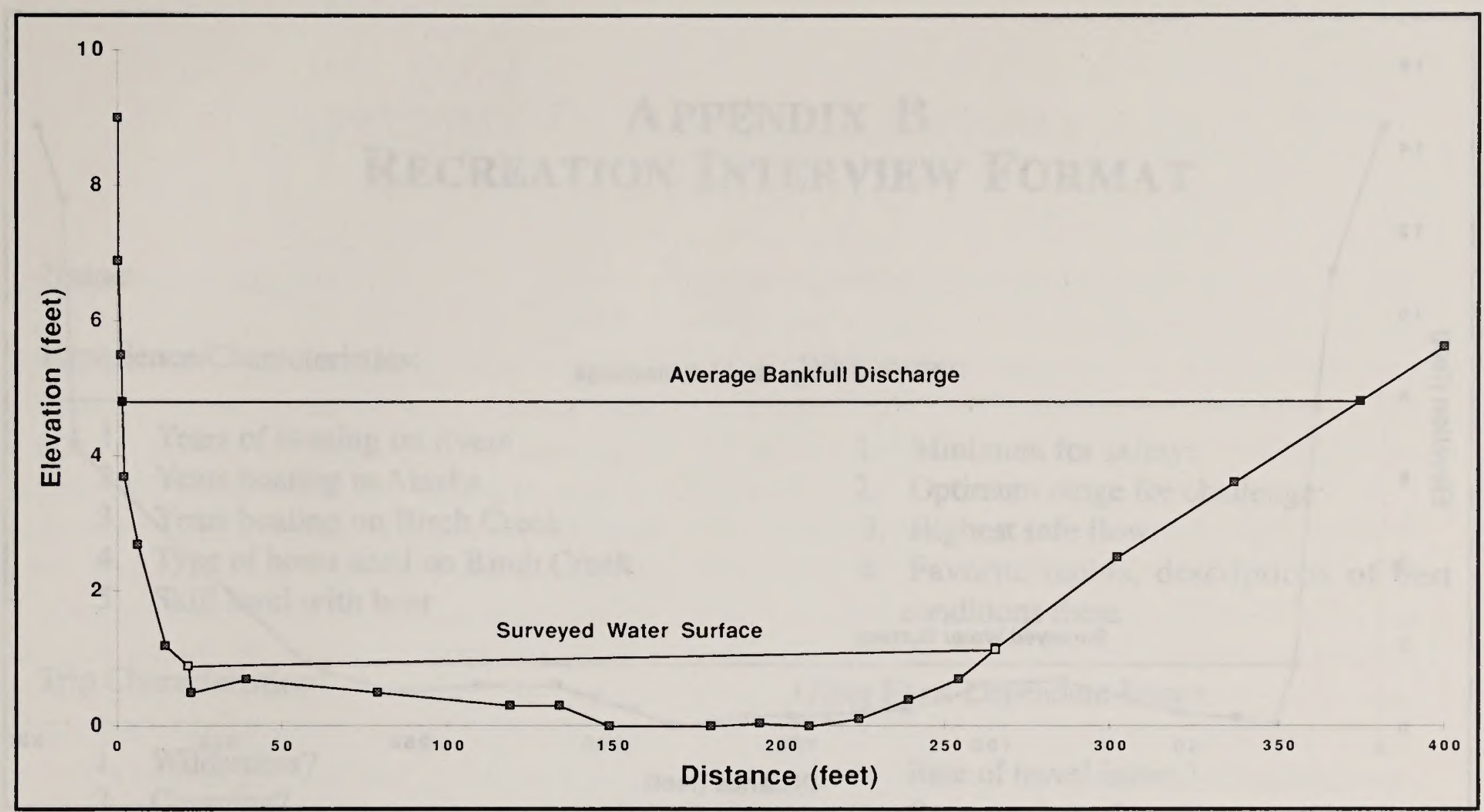

Figure 26. Channel cross-section for Birch Creek below South Fork.

Table 23. Rating table for Birch Creek below South Fork.

\begin{tabular}{c|c|c|c|c|c|c}
\hline $\begin{array}{c}\text { DEPTH } \\
(\mathbf{f t})\end{array}$ & $\begin{array}{c}\text { DISCHARGE } \\
(\mathbf{f f s})\end{array}$ & $\begin{array}{c}\text { VELOCITY } \\
(\mathbf{f t} / \mathbf{s})\end{array}$ & $\begin{array}{c}\text { AREA } \\
\left(\mathbf{f t}^{2}\right)\end{array}$ & $\begin{array}{c}\text { WETTED } \\
\text { PERIMETER }(\mathbf{f t})\end{array}$ & $\begin{array}{c}\text { HYDRAULIC } \\
\text { RADIUS (ft) }\end{array}$ & $\begin{array}{c}\text { TOP } \\
\text { WIDTH (ft) }\end{array}$ \\
\hline 0.2 & 10 & 0.63 & 16 & 95 & 0.17 & 95 \\
\hline 0.6 & 79 & 1.10 & 72 & 194 & 0.37 & 194 \\
\hline 1.0 & 276 & 1.71 & 161 & 234 & 0.69 & 234 \\
\hline 1.4 & 588 & 2.27 & 259 & 254 & 1.02 & 253 \\
\hline 1.8 & 1,014 & 2.79 & 364 & 269 & 1.35 & 268 \\
\hline 2.2 & 1,552 & 3.27 & 474 & 284 & 1.67 & 284 \\
\hline 2.6 & 2,208 & 3.74 & 591 & 299 & 1.98 & 299 \\
\hline 3.0 & 2,991 & 4.20 & 713 & 314 & 2.27 & 313 \\
\hline 3.4 & 3,907 & 4.65 & 841 & 328 & 2.57 & 327 \\
\hline 3.8 & 4,968 & 5.10 & 975 & 342 & 2.85 & 341 \\
\hline 4.2 & 6,190 & 5.56 & 1,114 & 355 & 4.37 & 354 \\
\hline 4.6 & 7,574 & 6.02 & 1,258 & 368 & 3.42 & 367 \\
\hline 5.0 & 9,134 & 6.49 & 1,408 & 381 & 3.69 & 380 \\
\hline 5.4 & 10,880 & 6.97 & 1,562 & 394 & 3.96 & 393 \\
\hline 5.6 & 11,830 & 7.21 & 1,641 & 400 & 3.10 & 399 \\
\hline
\end{tabular}




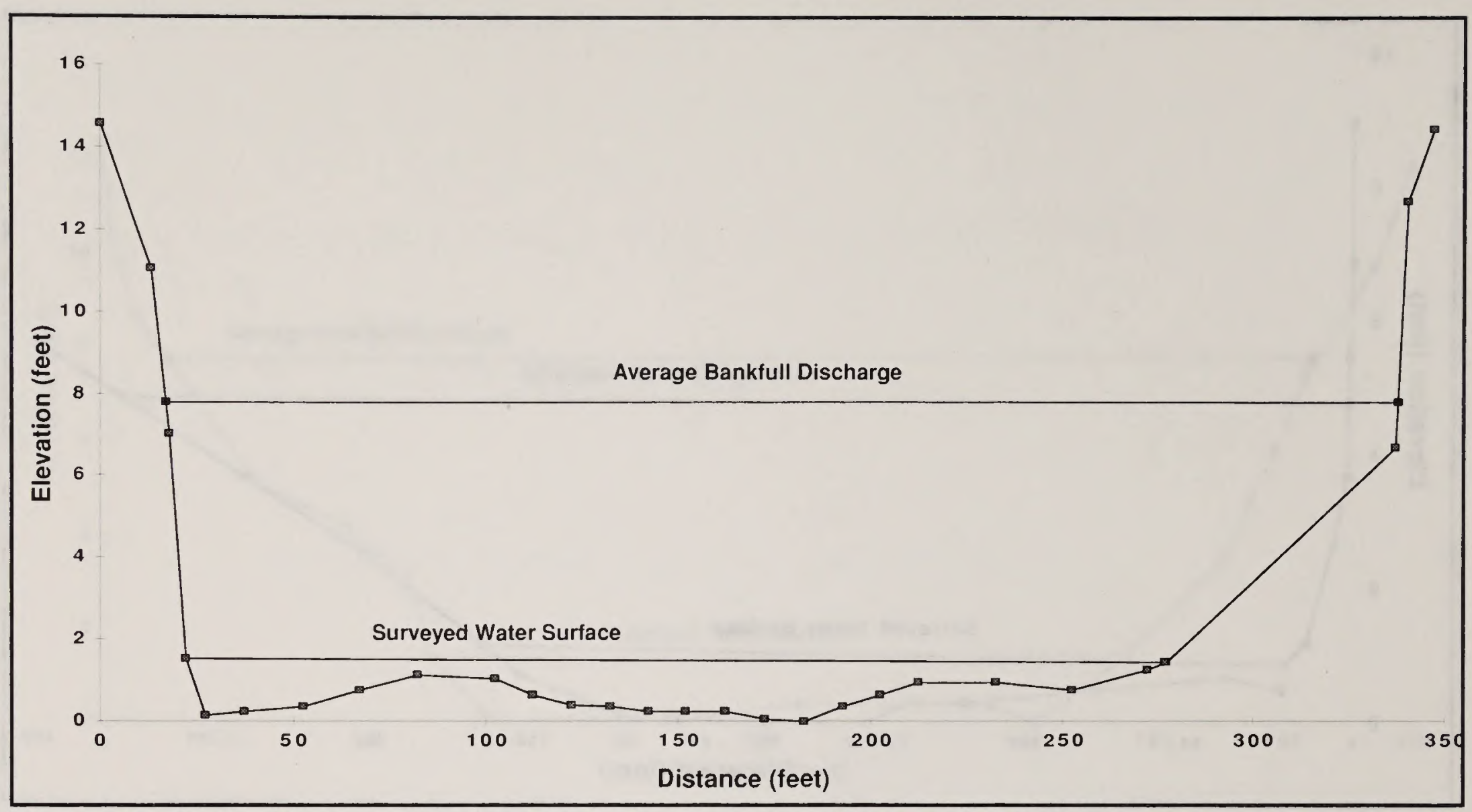

Figure 27. Channel cross-section for Birch Creek at Steese Highway Bridge.

Table 24. Rating table for Birch Creek at Steese Highway Bridge.

\begin{tabular}{c|c|c|c|c|c|c}
\hline $\begin{array}{c}\text { DEPTH } \\
(\mathrm{ft})\end{array}$ & $\begin{array}{c}\text { DISCHARGE } \\
(\mathbf{c f s})\end{array}$ & $\begin{array}{c}\text { VELOCITY } \\
(\mathrm{ft} / \mathbf{s})\end{array}$ & $\begin{array}{c}\text { AREA } \\
\left(\mathrm{ft}^{2}\right)\end{array}$ & $\begin{array}{c}\text { WETTED } \\
\text { PERIMETER (ft) }\end{array}$ & $\begin{array}{c}\text { HYDRAULIC } \\
\text { RADIUS (ft) }\end{array}$ & $\begin{array}{c}\text { TOP } \\
\text { WIDTH (ft) }\end{array}$ \\
\hline 1.0 & 145 & 1.50 & 97 & 201 & 0.48 & 200 \\
\hline 1.4 & 343 & 1.75 & 196 & 255 & 0.77 & 255 \\
\hline 1.8 & 578 & 1.93 & 300 & 260 & 1.15 & 260 \\
\hline 2.2 & 873 & 2.15 & 406 & 266 & 1.53 & 265 \\
\hline 2.6 & 1,220 & 2.38 & 514 & 271 & 1.90 & 270 \\
\hline 3.0 & 1,621 & 2.60 & 624 & 276 & 2.26 & 275 \\
\hline 3.4 & 2,074 & 2.82 & 736 & 281 & 2.62 & 280 \\
\hline 3.8 & 2,583 & 3.04 & 850 & 286 & 2.97 & 285 \\
\hline 4.2 & 3,147 & 3.26 & 966 & 292 & 3.31 & 290 \\
\hline 4.6 & 3,769 & 3.48 & 1,084 & 297 & 3.65 & 29 \\
\hline 5.0 & 4,451 & 3.70 & 1,204 & 302 & 3.99 & 29 \\
\hline 5.4 & 5,194 & 3.92 & 1,326 & 307 & 3.32 & 300 \\
\hline 5.8 & 6,001 & 4.14 & 1,450 & 312 & 3.64 & 310 \\
\hline 6.2 & 6,874 & 4.36 & 1,576 & 318 & 4.96 & 315 \\
\hline 7.0 & 8,855 & 4.83 & 1,833 & 325 & 3.65 & 321 \\
\hline
\end{tabular}




\section{A PPENDIX B RECREATION INTERVIEW FORMAT}

Name:

Experience/Characteristics:

Whitewater:

1. Years of boating on rivers

2. Years boating in Alaska

3. Years boating on Birch Creek

4. Type of boats used on Birch Creek

5. Skill level with boat

Trip Characteristics:

1. Minimum for safety:

2. Optimum range for challenge:

3. Highest safe flow:

4. Favorite rapids, descriptions of best conditions there

Other Flow-Dependent Issues:

1. Wilderness?

1. Rate of travel issues?

2. Camping?

3. Whitewater challenge?

4. Fishing?

5. Boatability?

2. Camp on bars; how important?

3. Aesthetic issues?

4. Wildlife that are important to see?

Sensitivity to flows:

1. Aware in general?

2. What gage or landmark used to assess flows?

3. Do flows influence when trips are taken?

4. Do flows influence how you take trips (where to camp, what to bring)?

5. If flow information was available, would you use it?

Overall flow evaluations:

1. Last trip and dates; evaluation.

2. Other trips and evaluations.

Boatability:

1. Critical reaches.

2. Minimum to get downriver.

3. Optimum level for navigation.

4. Tolerance for hits, stops and drags. 


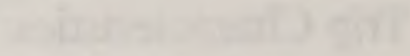

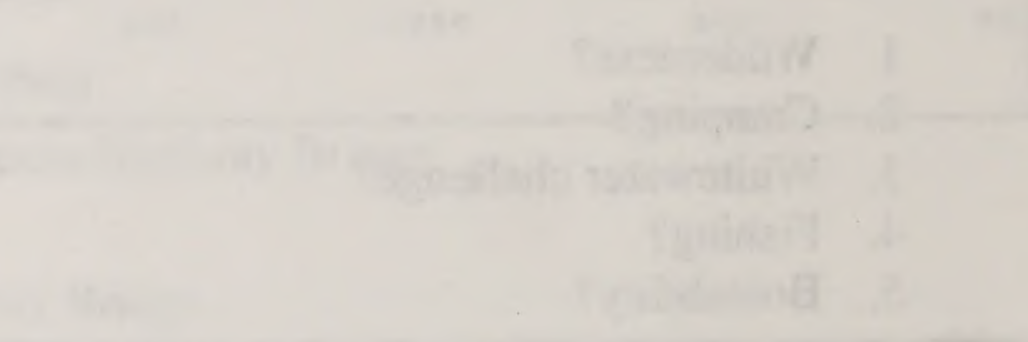




\section{APPENDIX C: RIPARIAN REPORT}

\section{By Brian A. Bogaczyk*}

Riparian areas are generally defined as a zone of unique vegetation bordering flowing waters, lakes and wetlands. In Alaska, riparian areas are composed of grasses and forbs, deciduous shrubs and trees. Riparian vegetation along Birch Creek is composed of 1) forests (coniferous, deciduous and mixed) 2) shrub communities (willows (Salix), alder (Alnus crispa) and dwarf birch (Betula nana and Betula glandulosa), and 3) herbaceous communities (composed of cottongrass (Eriophorum spp.), other sedges (Carex spp.) and ericaceous shrubs) (Viereck et al. 1992).

\section{Methods}

Current BLM procedure for asserting water rights attempts to reserve a minimum in-stream flow. As a result, water rights assessment documents produced by the BLM, such as the Rio Chama Instream Flow Assessment (Fogg et al. 1992) and Dolores River Instream Flow Assessment (Vanadas et al.1990), base much of their rational for asserting water rights on the assumption that water quantity is the limiting factor in determining composition of riparian vegetation. However, for Interior Alaska, the literature does not support this assumption. Instead, the literature describes Alaska ecosystems as heat-limited, not water-limited (Van Cleve et al. 1986). High-flow periods determine permafrost distribution, and therefore control composition of riparian plant communities. Also, the importance of ensuring adequate flow during the growing season to prevent mortality of seedling herbaceous and woody vegetation within the main channel, along low banks and gravel bars is discussed.

A literature search was done to elucidate ecological processes that determine composition of riparian vegetation communities in Interior Alaska. Knowledge gained by interviewing ecologists and botanists

* Formerly a BLM botanist, Fairbanks, AK

Now a USFWS biologist, Olympia, WA. supplemented data gained from the literature. For the purposes of this document, the terrestrial riparian zone is defined as any area in or adjacent to a drainageway, or its floodplain, and is characterized by species different than those of surrounding communities.

A channel cross section was established on Birch Creek about 1,500 feet above Clums Fork during the resource assessment trips in June and July 1990. This site was selected to represent riparian vegetation structure because the floodplain is relatively wide ( $>1$ mile) and meanders of Birch Creek and Clums Fork created a mosaic of wetlands and upland vegetation types. Also, because substantial amounts of deciduous browse are present, the site can be considered representative of high-quality moose wintering areas found along Birch Creek.

\section{Resource Value}

Stands of large white spruce (Picea glauca) balsam poplar (Populus balsamifera), and to a lesser extent, trembling aspen (Populus tremuloides) and paper birch (Betula papyrifera) occur on warm, welldrained soils in riparian areas. These soils are usually of alluvial origin. Understory vegetation often is high-bush cranberry, wild rose, forbs and grasses. Shrub communities of early successional species like willows, sapling Populus spp., and alder also occur on warm soils, e.g., point bars, abandoned channels and silt deposited during flood events. Open woodlands of scattered black spruce (Picea mariana) with understories of mosses, sedges and ericaceous shrubs occur on cold soils with reduced fertility and excess moisture. Where the permafrost table is nearing the surface, creating a permanently wet, cold and unproductive environment, trees cannot maintain vigor, and hence these sites are dominated by herbaceous communities, typically composed of cottongrass (Eriophorum spp.), other sedges (Carex spp.), mosses and ericaceous shrubs.

Unless a site is drastically disturbed, usually by fire or flooding or channel realignment, natural suc- 
cession tends toward development of permafrost soil conditions. On river floodplains, active erosion and deposition result in a mosaic of vegetation types of varying successional stages. Newly deposited silt bars (alluvial soils) or recently abandoned stream channels are composed of warm, permafrost-free soils that have high nutrient content and cation exchange capacity (Juday and Zasada 1982). These soil characteristics are favorable for growth of soil microorganisms and plants.

Invasion of recently disturbed sites by plants follows a fairly predictable sequence. Succession begins with willows and forbs colonizing the site, usually followed by alders, to form a dense shrub community. Balsam poplars become established, and eventually develop into forests (most productive vegetation type in Interior Alaska, characterized by rapid nutrient cycling and warm soils,). The dense willow and alder understory persists, but gradually begins to thin as the poplars form a closed canopy. White spruce can become established in either the shrub or balsam poplar stage, and will persist in the understory until the poplars reach maximum age (60-100 years) and begin to topple. The forest canopy is opened up, releasing white spruce, which become dominant. Gradually, as succession proceeds, nutrients become tied up in living and dead plant matter. Duff, and especially mosses on the forest floor, accumulate and insulate the soil from heat sources during the brief subarctic summer. Over decades, soil temperatures gradually cool, and because the ability of the plants to uptake nutrients is temperature dependent, the site's capacity for primary productivity is gradually reduced. Several generations of white spruce may occupy a site before soil conditions are no longer favorable for their reproduction and survival. If not catastrophically disturbed by channel realignment, inundation by flooding or fire, permafrost conditions will develop (i.e., soil temperature and productivity decline and moisture becomes excessive) and black spruce invade. Eventually black spruce out-compete white spruce for growing space, as commonly seen on older river terraces. The permafrost table continues to rise nearer to the surface, creating continually shallower rooting zones and soils that are saturated and cold throughout the growing season. Usually, the climax vegetation community to persist on such a site is an herbaceous type composed of cottongrass (Eriophorum spp.), other sedges, ericaceous shrubs and scattered black spruce. These sites are characterized by low species diversity and productivity (Van Cleve et al. 1986, Van Cleve et al. 1980, Viereck 1970).

In the taiga environment, disturbance caused by high-flow events often determine the distribution of permafrost, and hence riparian vegetation communities (Van Cleve et al. 1986). In fact, the primary determinant of the plant communities in riparian areas is the time since the river deposited the substrate. For example, flood events alter channel morphology by creating oxbows, point bars and side bars. Deposited silt and abandoned river channels are free of permafrost and nutrient-rich, and are rapidly colonized by early successional plants. High flows, when accompanied by ice flows, scour gravel bars, thus creating seedbeds or shear off willow spp. and Populous spp., which rebound quickly by sprouting and suckering. Finally, extreme flood events that inundate the floodplain remove insulating duff and moss, which permits soil temperatures to rise, thus creating more productive growing conditions.

In addition to determining location of permafrost soils by erosion and deposition, high flow, especially overbank flows, have major effects on seed dispersal, seedling survival and growth of riparian vegetation (Hill et al. 1991). Also, floodplains receive large quantities of nutrients, silt, and organic matter during overbank floods, which serve to maintain riparian communities in a productive growth stage, and if reduced, can enable non-riparian species to invade riparian zones (Hill et al. 1991).

\section{Importance of Ensuring Minimum Flow}

Though minimum flow is of primary importance to ensure continuation of flood events, it is also important to ensure a certain minimum instream flow during summer. July and early August are moisturelimited for plants in the Interior, especially newly established seedlings on exposed gravel bars. As flow levels drop, the groundwater table also begins to recede, and shallowly rooted seedlings are unable to get moisture and wither. Older perennial plants usually have root systems that extend down to more reliable soil moisture, and hence are more likely to weather a drought. However, low flows required to maintain fish populations and recreational values will likely be sufficient to maintain seedling riparian vegetation. 


\section{Fish and Wildlife Populations Supported by Riparian Habitats}

Plant communities growing in riparian zones, especially on recent alluvial soils, often have higher primary productivity than surrounding upland areas [annual above-ground tree productivity ranged from $264-952 \mathrm{~g} / \mathrm{m}^{2}$ in balsam poplar stands to about $14 \mathrm{~g} /$ $\mathrm{m}^{2}$ in permafrost black spruce in test plots in Tanana Flats (Van Cleve et al. 1986)]. Accompanying higher productivity is greater species diversity and numbers of individuals per unit area.

Deciduous forests and shrublands in Interior Alaska that are growing on productive alluvial soils provide substantial amounts of browse. These areas, considering their relative availability on the landscape, are disproportionately important to herbivores, and support relatively high populations of moose (Alces alces), hares (Lepus americanus), microtines and invertebrates. These populations in turn support higher trophic levels such as wolves (Canis lupus), lynx (Felis lynx), mustelids and birds (especially raptors) dependent on microtines, and neotropical migrants dependent on invertebrates.

Large "old-growth" white spruce and large decadent balsam poplar growing in riparian areas provide habitat for cavity nesters such as marten (Martes americana), northern flying squirrel (Glaucomys sabrinus), boreal owls (Aegolius funereus), hawk owls (Surnia ulula), woodpeckers (Picoides spp.), chickadees (Parus spp.), bufflehead ducks (Bucepahala albeola), common mergansers (Mergus merganser americanus) and other species. Many cavity nesters require trees $>12$ " DBH, and trees of this size are only found in riparian areas in upper Birch Creek drainage.

Large woody debris (LWD) is an important component of stream ecosystem function in forested watersheds (Murphy and Koski 1989). Instream LWD creates pools and eddies important to fish populations, and large trees grown in riparian forests are the only sources of LWD in Alaska ecosystems. Also, riparian forests contribute to secondary productivity of aquatic ecosystems by adding nutrients in the form of leaf litter and twigs (detritus). Fungal, microbial and macroinvertebrate populations are dependent on these inputs of detritus (Cummins et al. 1989). Forested stream ecosystems depend on energy input from abscised leaves of riparian trees. After entering the stream, leaves quickly lose mass due to leaching of soluble nutrients, then are colonized by fungi and bacteria. Eventually, leaves become palatable to another species assemblage of invertebrates called shredders (Irons et al. 1991, Cummins et al. 1989). LWD also contributes a gradual release of nutrients as it slowly decomposes (Murphy and Koski 1989). Terrestrial invertebrates, such as defoliators, as well as other invertebrates that prey on them, such as beetles, frequently cling to riparian vegetation overhanging the streams, fall into the water and contribute energy to the aquatic ecosystem.

Hill et al. (1991) state that frequently the weakest link in most instream flow analyses is assessing importance of riparian vegetation in ensuring long-term channel stability and form. Root systems of stream bank vegetation hold soil in place and reduce erosion, and tree boles and LWD divert water flow away from vulnerable stream banks and reduce current velocities. Also, riparian vegetation along stream banks influences water quality parameters, such as amounts of incident light and suspended solids, and water temperature.

\section{Clums Fork Field Site}

Figure 9 is a graphical representation of a stream cross section that was established at the Clums Fork site, which was chosen as representative of high-quality moose wintering habitat found along Birch Creek. Both banks were densely vegetated with willows and alder, providing bank stability and forage for herbivores. Cross-section measurements did not include the floodplain area, which is where most of the riparian vegetation communities occur. However, examining topographic maps and aerial photos indicate that the Clums Fork site is representative of the reach below Harrington Fork: a broad floodplain maintained by periodic inundation, with sweeping meanders that create sloughs, and erosional processes that deposit warm, nutrient-rich silt that produce productive vegetation communities. 



\section{Literature Cited}

Cummins, K.W., M.A. Wilzbach,, D.M. Gates, J.B. Perry and W.B. Taliaferro. 1989. Shredders and riparian vegetation. Bioscience 39: 24-30.

Fogg, J.L.; B.L. Henry, H.T. Mottl, D.P. Muller, R.C. Eaton and S. Swanson. 1992. Rio Chama instream flow assessment. U.S. Department of the Interior-Bureau of Land Management, Denver Service Center 75pp. plus appendices.

Hill, M.A.; W.S. Platts and R.L. Beschta. 1991. Ecological and geomorphological concepts of instream and outof-stream flow requirements. Rivers 2:198-210.

Irons, III, J.G; J. P. Bryant and M.W. Oswood. 1991. Effects of moose browsing on decomposition rates of litter in a subarctic stream. Can. J. Fish. Aquat. Sci. 48:442-444.

Juday, G.P and J.C. Zasada. 1982. Structure and development of an old-growth white spruce forest on an interior Alaskan floodplain. Pp. 227-234 In Meehan, W.R., T.R. Merrell, Jr., and T.A. Hanley, eds. 1984. Fish and wildlife relationships in old-growth forests: proceedings of a symposium held in Juneau, Ak., 12-15 April 1982. Amer. Inst. Fish Res. Biol. $425 \mathrm{pp}$.

Murphy, M.L. and K.V. Koski. 1989. Input and depletion of woody debris in Alaska streams and implications for streamside management. N. Am. J. Fish. Manag. 9:427-436.

Vanadas, S.; D. Whittaker, D. Murphy, D. Pritchard, L. MacDonnell, B. Shelby, D. Muller, J. Fogg, B. Van Havern 1990. Dolores River instream flow assessment. U.S. Department of the Interior-Bureau of Land Management, Denver Service Center 92 pp. plus appendices.

Van Cleve, K.; T. Dyrness and L. Viereck. 1980. Nutrient cycling in Interior Alaska flood plains and its relationship to regeneration and subsequent forest development. Pp. 11-18, In Murray, M. and R.M. Van Vedhuizen, eds. 1980. Forest regeneration at high latitudes. Proc. of an International Workshop, Nov. 15-17, 1979. (Fairbanks, AK) USDA For. Serv.

Gen. Tech. Rpt. PNW-107.
Van Cleve, K.; F.S. Chapin III, P.W. Flanagan, L.A. Viereck and C.T. Dyrness, eds. 1986. Forest ecosystems in the Alaskan taiga. Springer-Verlag, N.Y., N.Y. 225 pp.

Viereck, L.A. 1970. Forest succession and soil development adjacent to the Chena River in interior Alaska. Arctic and Alpine Res. 2:1-26.

Williams, G.P. 1978. Bankfull discharge of rivers. Water Resources Research, Vol. 14:6, 1141-1154.

Whittaker, Doug; B. Shelby, W. Jackson and R. Beschta. 1993. Instream Flows for Recreation: A Handbook on Concepts and Research Methods. National Park Service. 104 pp.

Williams, G.P. 1978. Bank-Full Discharge of Rivers. Water Resources Research V.4, N.6. pp. 1141-1154.

Zakharchenko, G.M. 1973. Migrations of the grayling (thymallus arcticus) in the upper reaches of the Pechora. Journal of Icthyology 13: 628-629. 



\section{A PPENDiX D: Field NOTES-1990}

\section{July 20 - Day One}

Friday afternoon, the team entered Birch Creek by way of Twelvemile Creek. The first day's float carried us approximately halfway to Harrington Fork. Water quality was excellent compared to the previous year. Stream substrate appeared clean, on the surface but close examination showed significant cementing (loss of interstitial spacing) in the substrate. This is the result of discharges (poor water quality) in the past from placer mining activity. Some macroinvertebrates were observed by turning over the substrate, but not the number observed in Twelvemile Creek.

Aquatic habitat features (structure) were diverse in this reach, with the quality being good. The riparian vegetation was a good mix of forest, scrub, and herbaceous communities. Streambanks were stable and provided important features like undercut banks. Pool/riffle ratio was in the range of $40 / 60$ to $60 / 40$. The pools, varying in size and depth, would provide good habitat for adults as well as sub-adults.

A larger number of fish were observed in this reach then we expected. This is related to the water quality taking place this year compared to past years. Most of these fish appeared to be sub-adult (juvenile) grayling.

\section{July 21-Day Two}

The first half of day two was spent floating to the confluence of Harrington Fork and Birch Creek, as well as collecting data (transect) at one site on Birch Creek to represent the reach from Twelvemile Creek to Harrington Fork. After Harrington Fork, the aquatic habitat of Birch Creek changed. The number of pools and the quality of pools declined. Most of this section of river is a combination of short riffles leading into long runs/glides. This held true to campsite \#2 (River Mile 20).

Water quality and the appearance of the substrate remained excellent, although there is significant ce- menting of the substrate. Fewer macroinvertebrates were observed in the mainstem than day one.

Again, the riparian vegetation was diverse and in excellent condition. Most streambanks were stable but there was some evidence of last summer's high flow.

A transect was located in this stretch of river to represent pool habitat for adult and sub-adult habitat during summer months.

Fewer fish were observed on day two and most of the fish caught were small sub-adult grayling, less than eight inches total length. We did observe what appeared to be large suckers in this stretch of river. Most of the fish caught were at the confluence of Harrington Fork and Birch Creek.

\section{July 22-Day Three}

From campsite \#2 to approximately $3 / 4$ mile below the confluence of Clums Fork, the river remained much the same as day two. However, there were small stretches within this reach that resembled habitat we observed between Twelvemile Creek and Harrington Creek. Also, around the area of Clums Fork we observed some large boulders in the system.

Riparian vegetation, water quality, stream substrate, bank stability and macroinvertebrates remained much the same as was observed from day one.

Very few fish were observed on day three and those that were caught were small grayling, less than seven inches total length. We did observe some suckers.

We established a transect above Clums Fork to determine flows to maintain riparian vegetation that provide important winter range for moose.

\section{July 23-Day Four}

Clums Fork to Portage Creek has long, shallow runs connected by short riffle areas. The area also 
contains a few deep pools, greater than six feet deep, that provide some habitat for sub-adults and adults. This reach had a steeper gradient from what was observed the previous two days.

Water quality remained excellent and streambank stability, substrate, macroinvertebrate, etc. remained as previously observed. The riparian vegetation was mostly forested communities with some scrubs (willow, alder).

Very few fish were observed in this section of river. Most of the fish we did observe were in deep pools, in an area above the confluence of Harrison Creek.

The excitement of day four was floating through a fire burning on the north side of Birch Creek. Areas that the fire had burned over left very good mosaic patterns that should benefit the watershed, vegetation succession, and wildlife.

\section{July 24 -Day Five}

On day five, we floated from Portage Creek to approximately two miles into the Yukon Flats. The aquatic habitat from Portage Creek to the entrance of the Yukon Flats was a series of short riffles into high-quality deep pools greater than six feet that extended into long glides. Leaving the mountains, the river's gradient, sinuosity, and vegetation changed significantly. It also became a more pronounced multi-channel system.

The riparian vegetation on the Yukon Flats contained many more aspen and the appearance of cottonwoods. Prior to the flats, the vegetation was mostly forested communities. Stability, macroinvertebrates, water quality, etc. remained the same as observed the previous days.

Few fish were observed or caught prior to the flats. Once in the flats, we observed and caught a number of grayling in the 7-to-12 inch range (total length).

We established a transect on South Fork to determine flows to insure the accessibility of adult grayling migrating into South Fork to spawn. We also established a transect on Birch Creek below South Fork for floatabliity.

\section{July 25-Day 6}

Day six was a repeat of the last two miles of day five. We traveled approximately 28 miles to camp- site \#6, just below the confluence of Crooked Creek and Birch Creek. The river is multiple-channel and would be described as a series of deep pools tailing into long runs connected by short riffles. At times, one-half of the rivers' flow would split off for several miles before rejoining. Most of the pools were of high quality, but some lacked instream cover (ex. woody debris).

The water quality in Birch Creek was excellent until we reached the confluence of Crooked Creek. Placer mining activity has discolored the river from this point on.

Macroinvertebrates, substrate and stability remained much the same as in the rest of the river. The riparian vegetation was a good mix of aspen, willow, alder, cottonwood, and forest communities.

Fish sampling produced only grayling, 7 to 12 inches in total length, except one that was 15 inches in total length.

A streamflow measurement was made on Birch Creek below Crooked Creek.

\section{July 26-Day 7}

On day seven, we traveled approximately one mile before portaging to the Steese Highway. The habitat was the same as was seen on day six. We established a transect below the portage to determine flows for adult grayling winter habitat.

Summary of Wildlife Observations: A wide variety of wildlife was observed by the team that floated Birch Creek from July 20, 1990 to July 26, 1990. Big game species included moose, caribou and black bear. Tracks left by grizzly bears and wolves were noted on several river bars. Among the important furbearers observed were a red fox and numerous beavers. Raptors included a good number of bald eagles, red-tailed hawks, as well as two pairs of peregrine falcons. Waterfowl was numerous throughout the system. 


\section{Appendix E: Detailed Maps of River Segments}

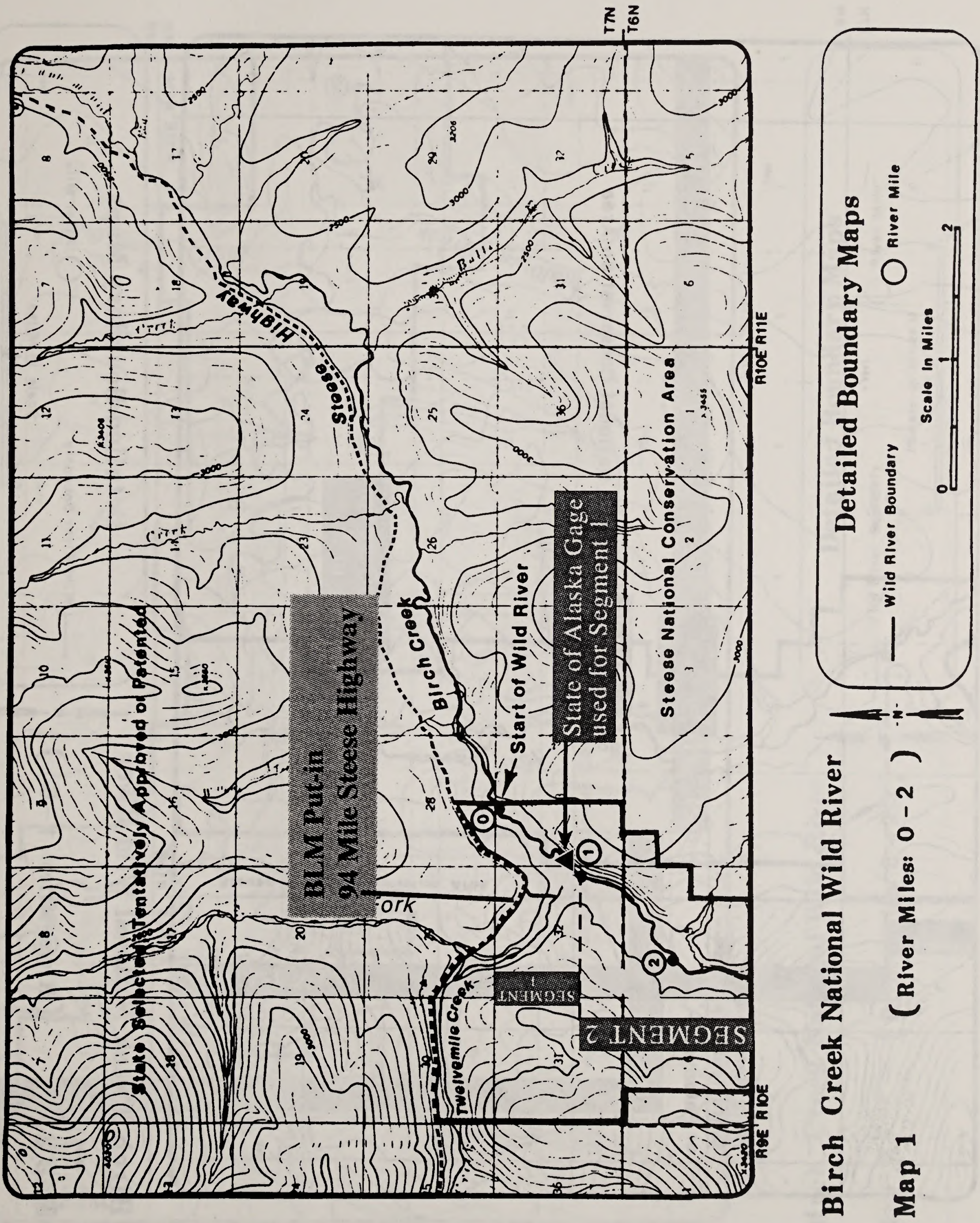




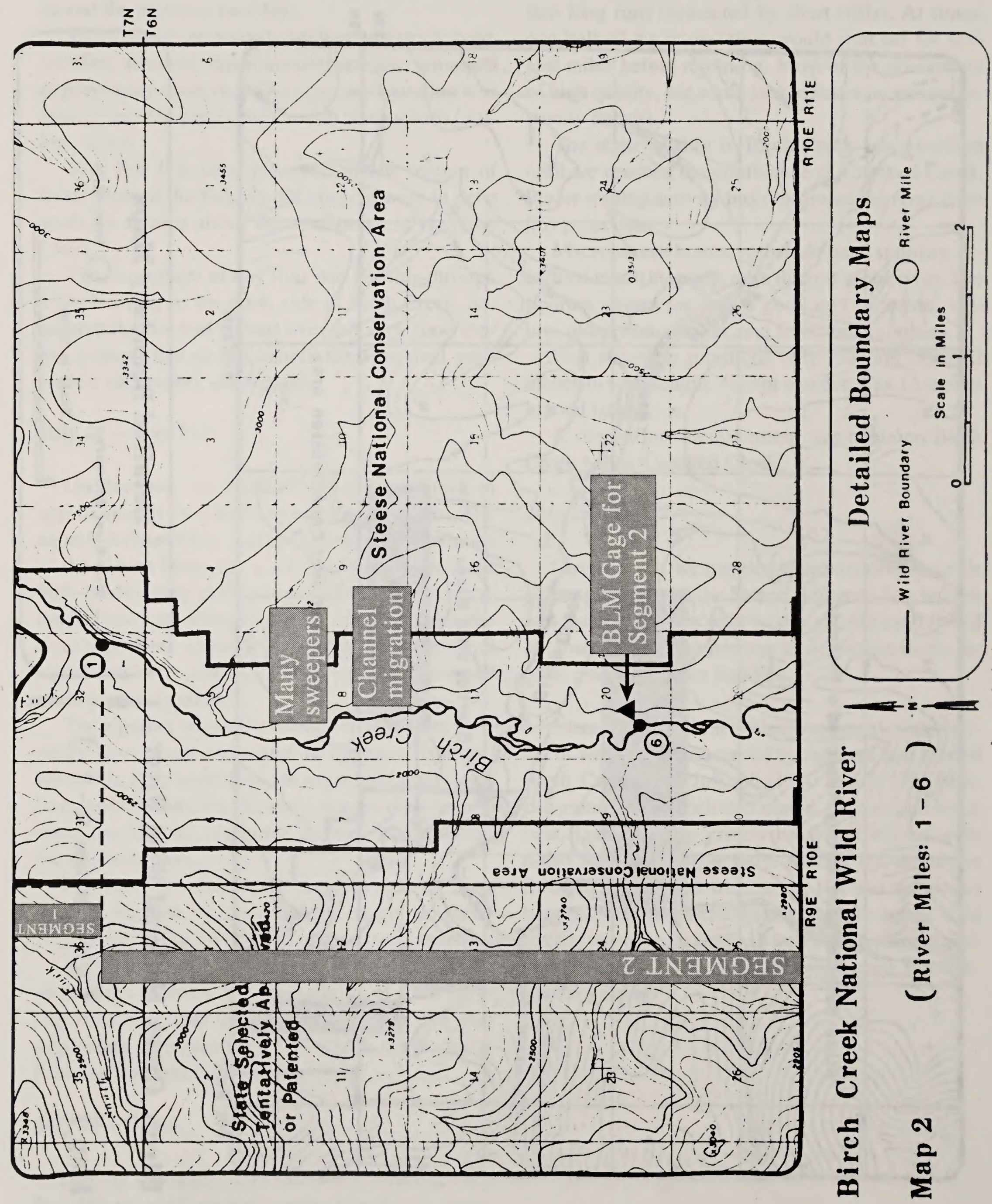




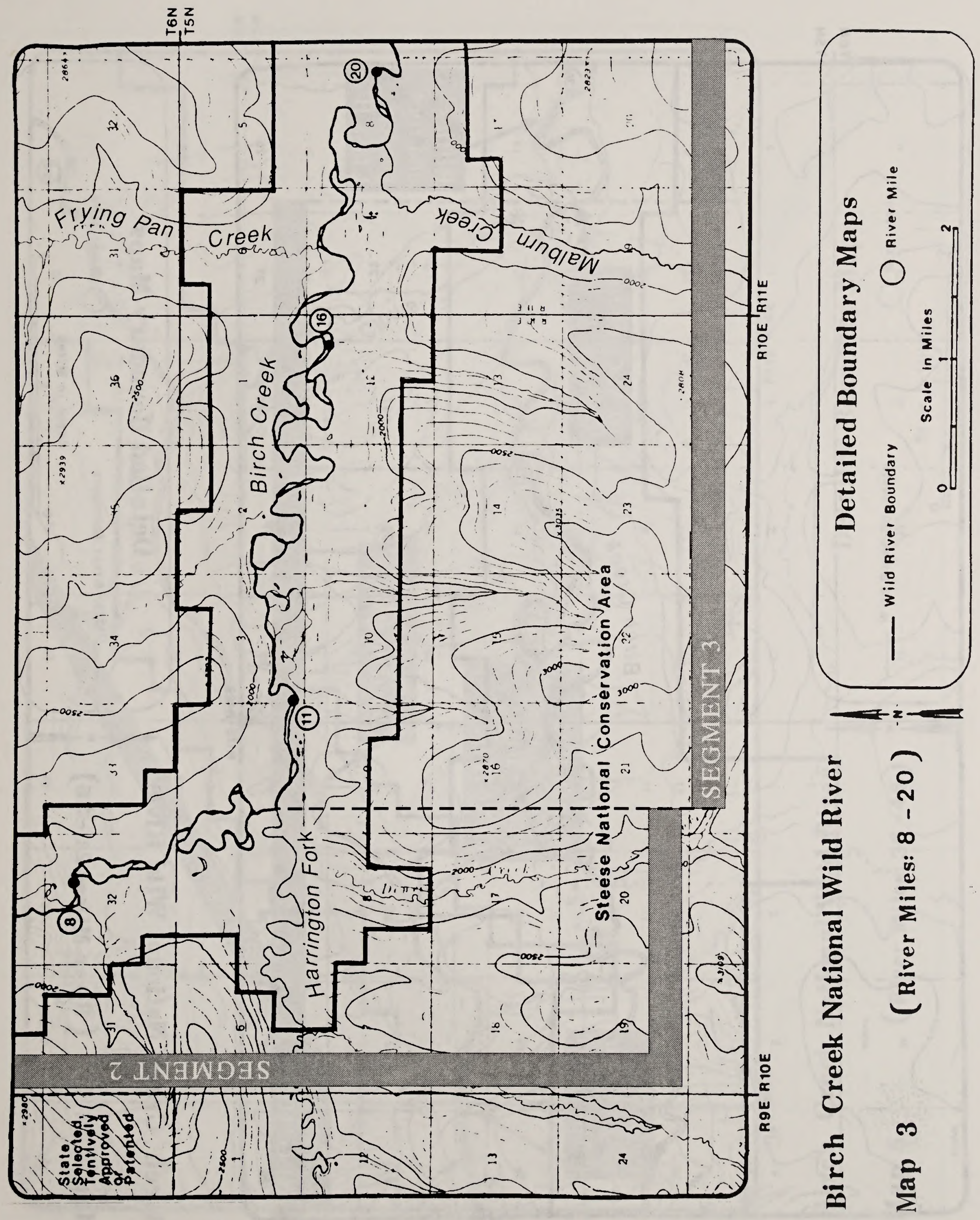



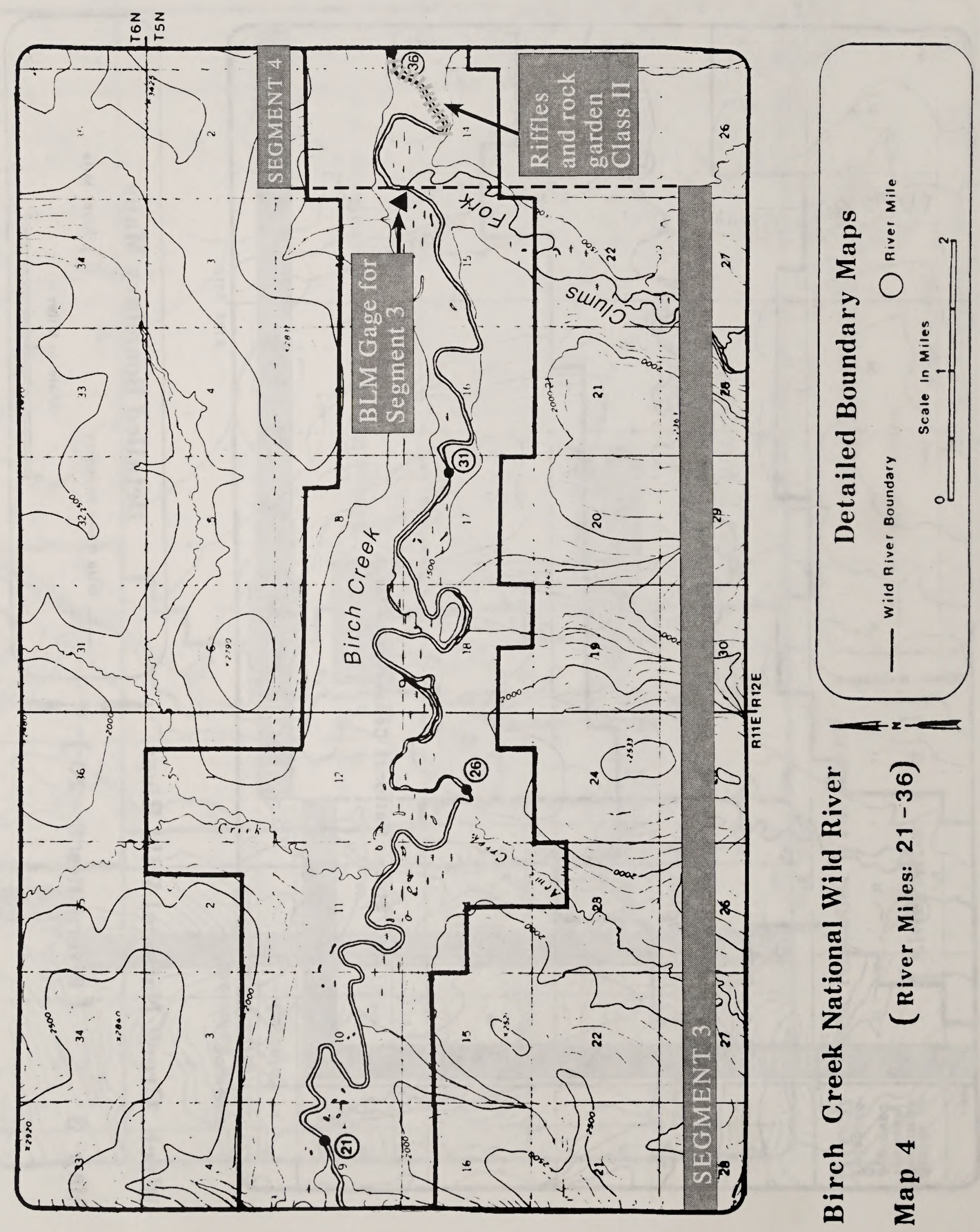


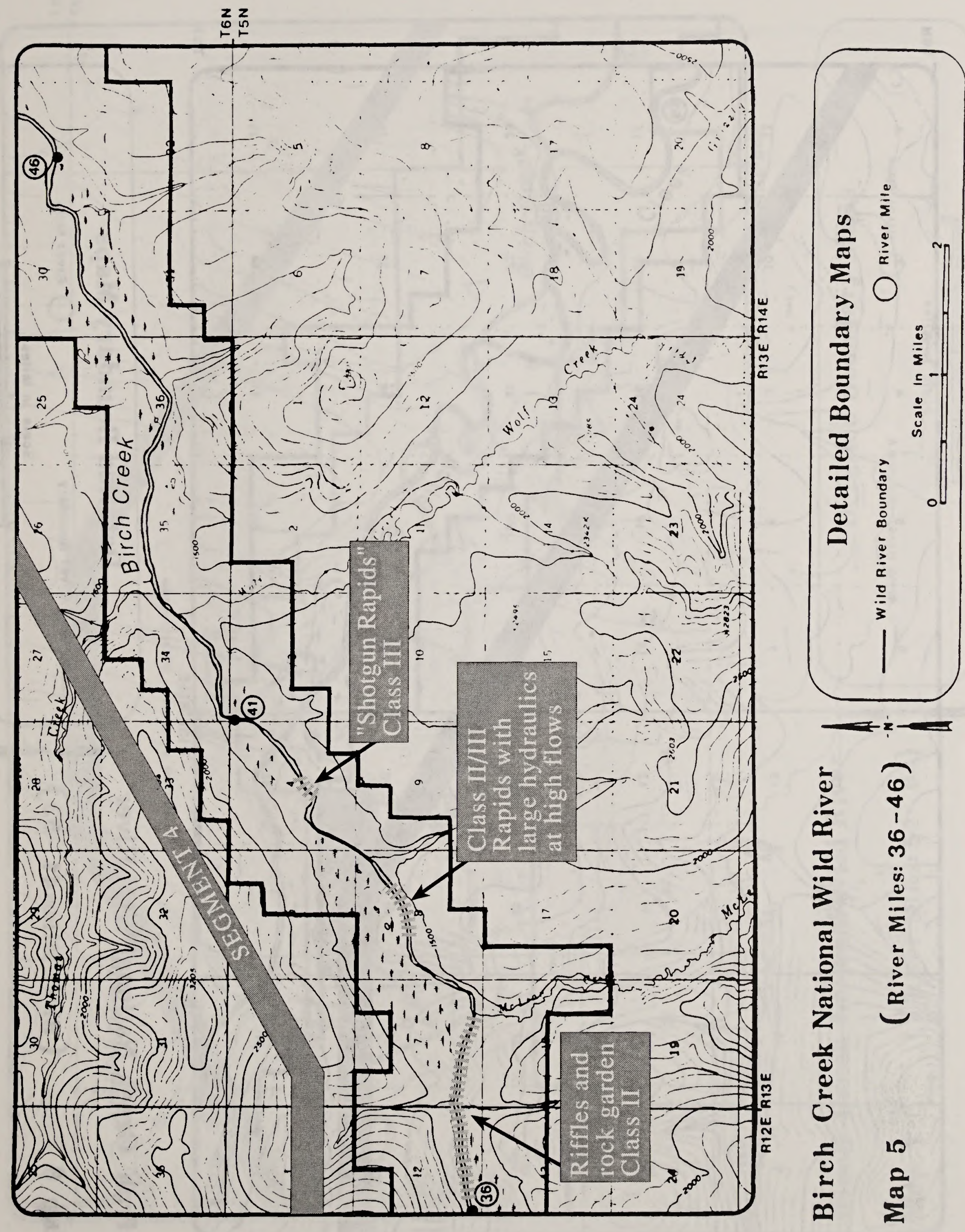




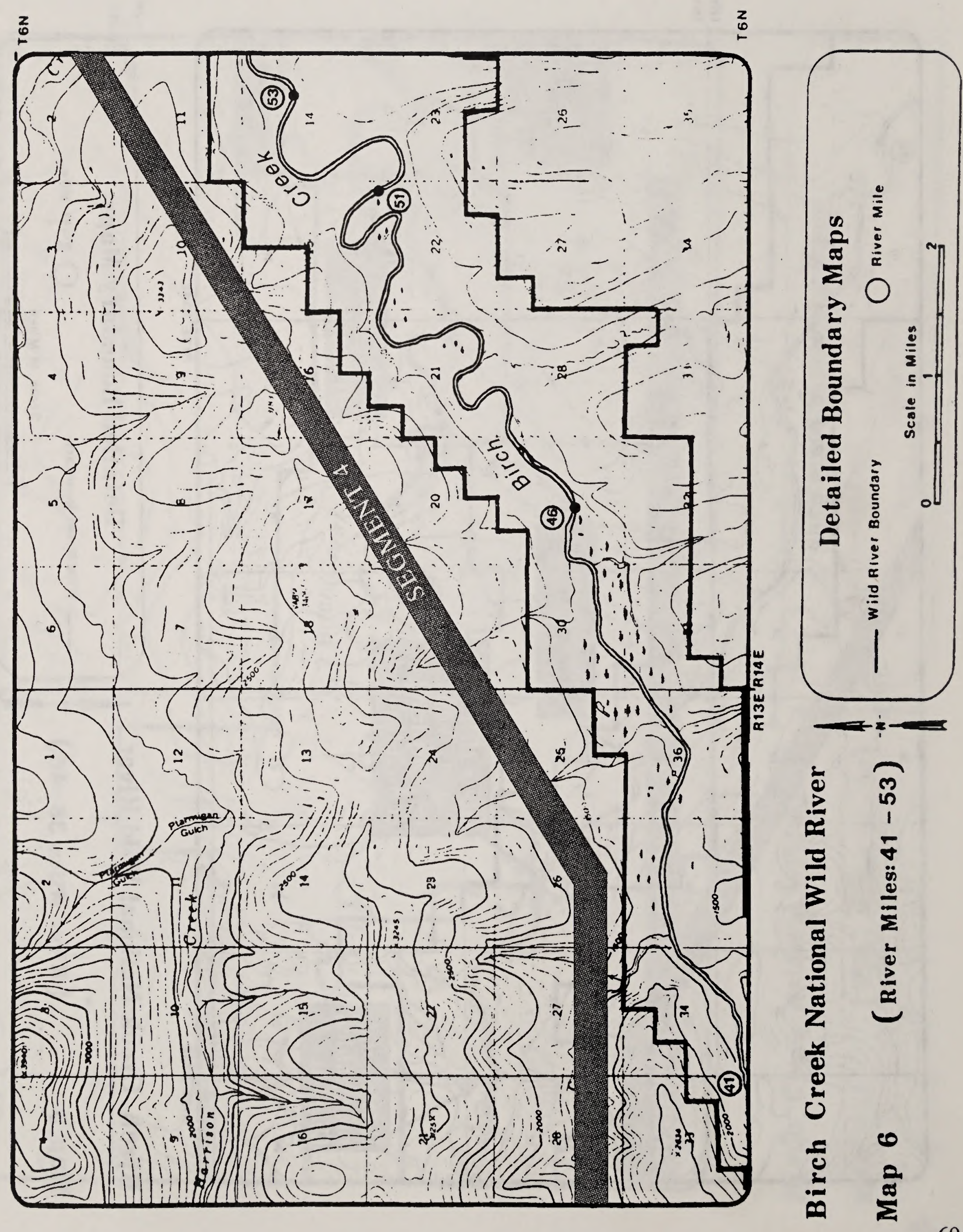







zo

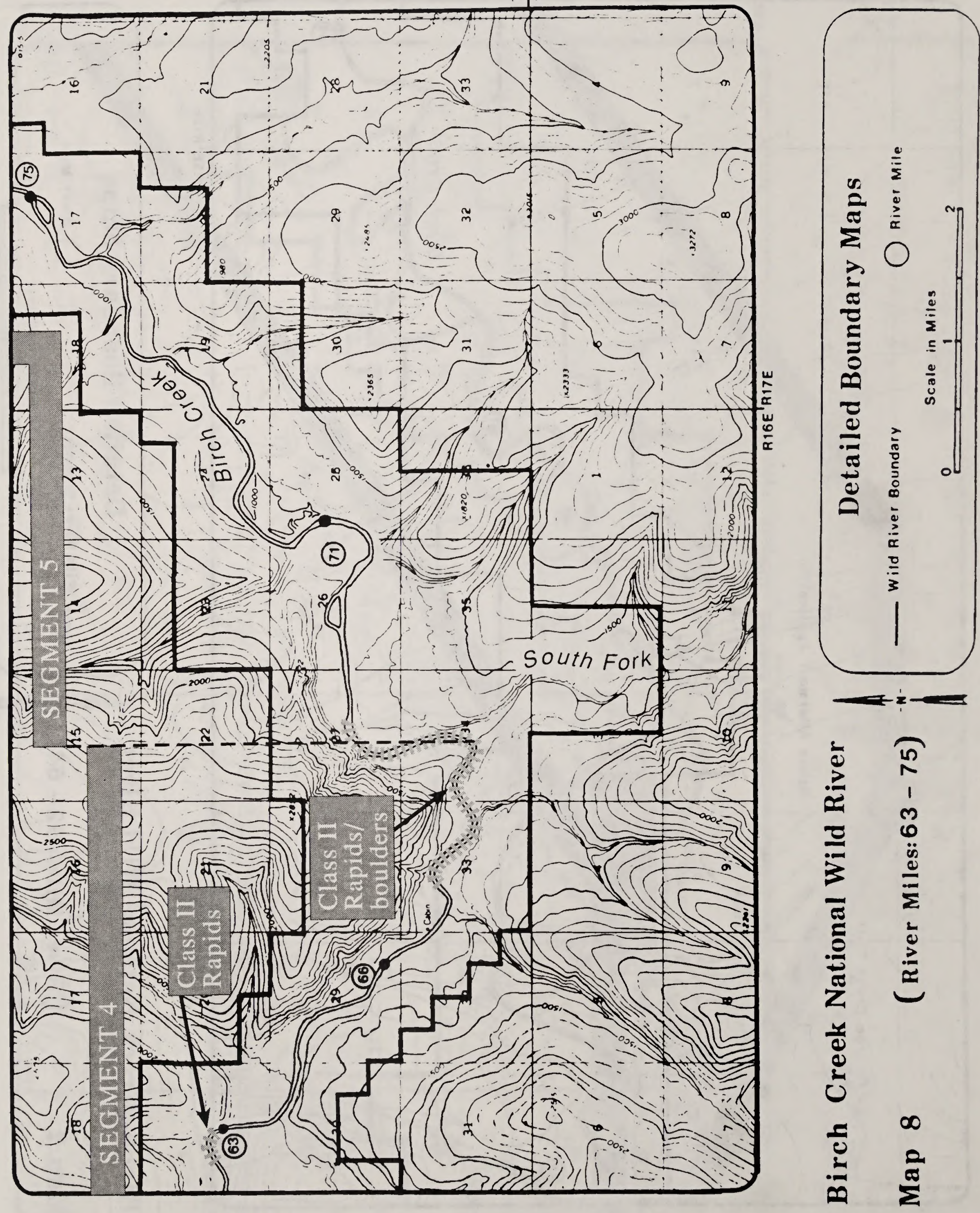




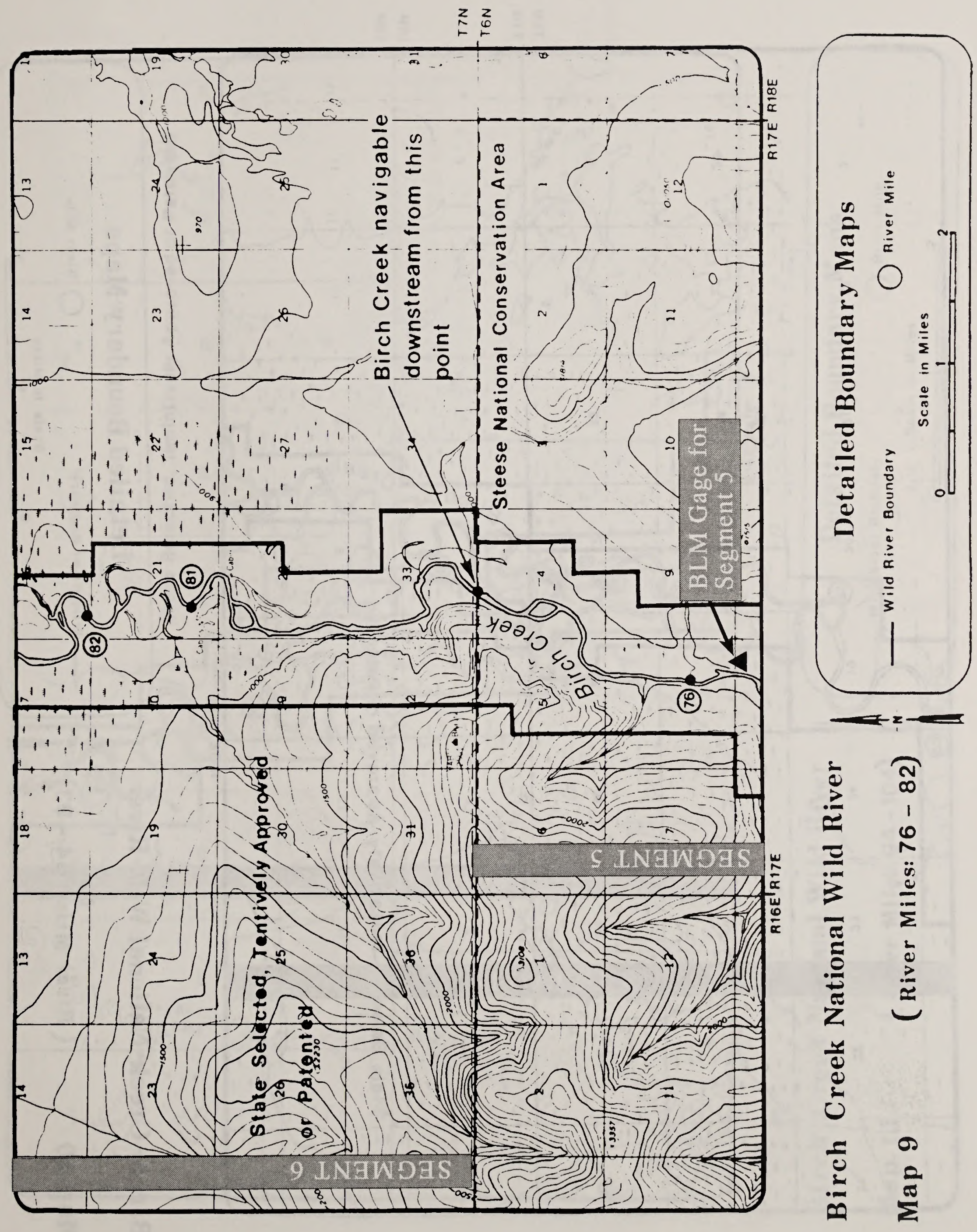


혼?
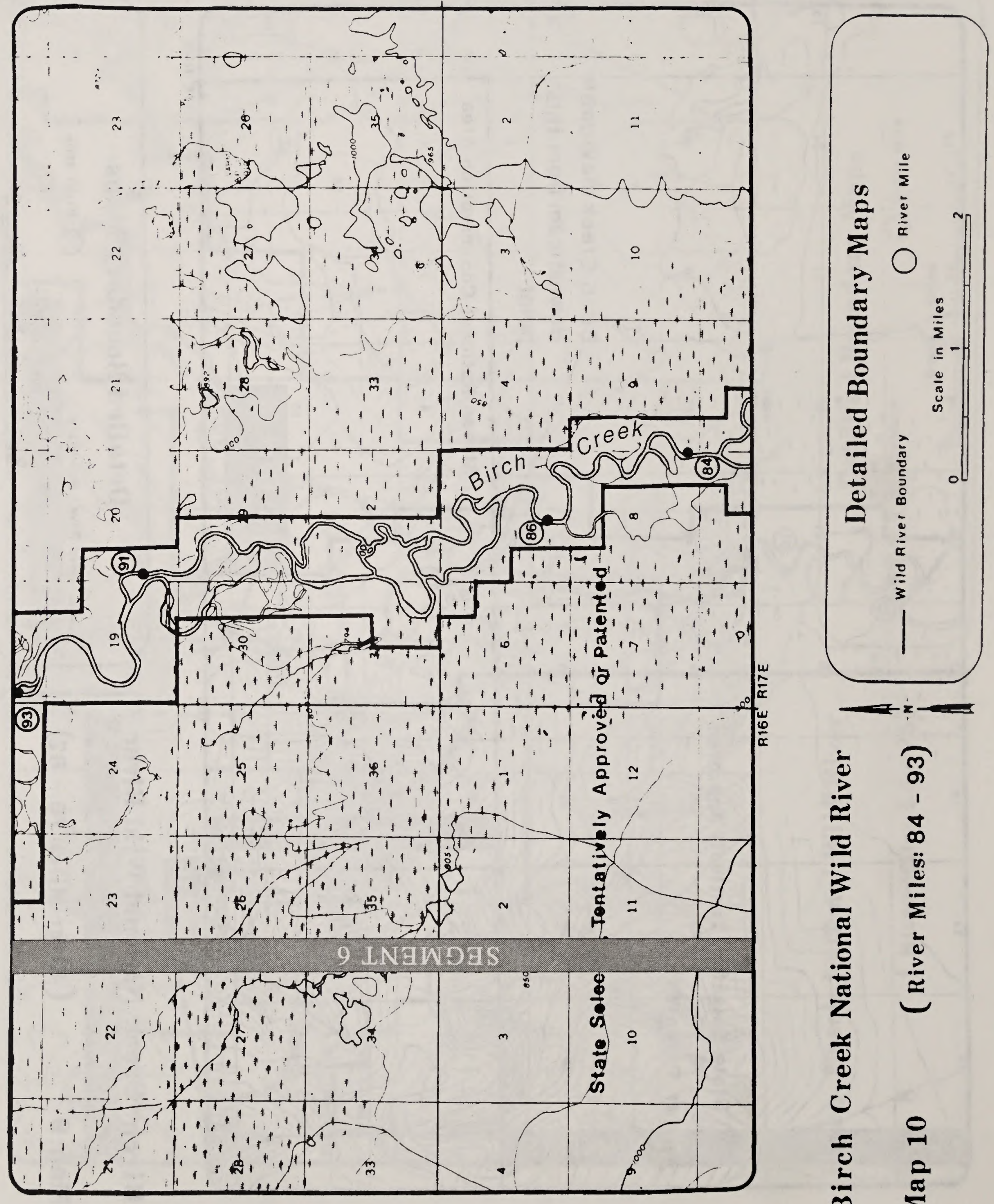

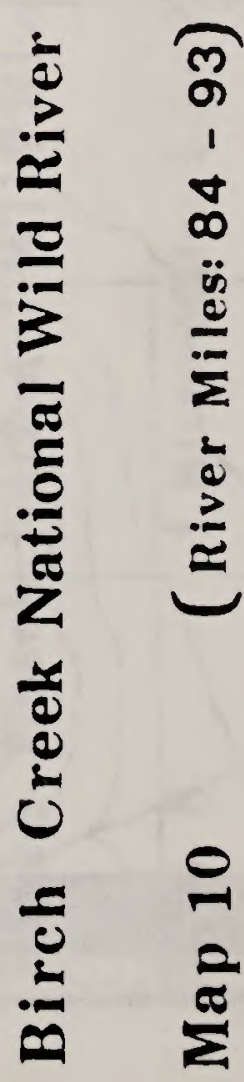




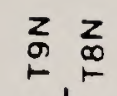

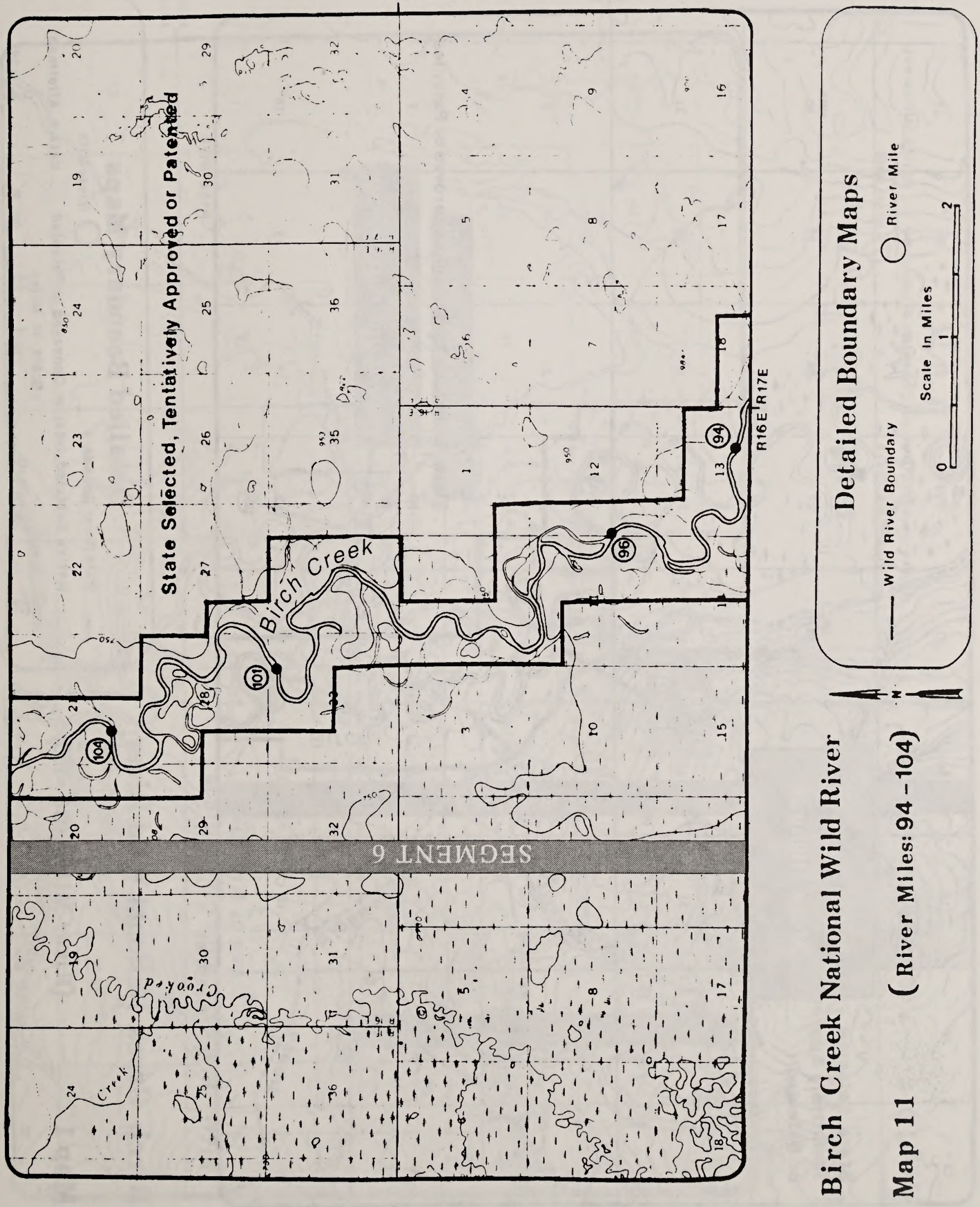




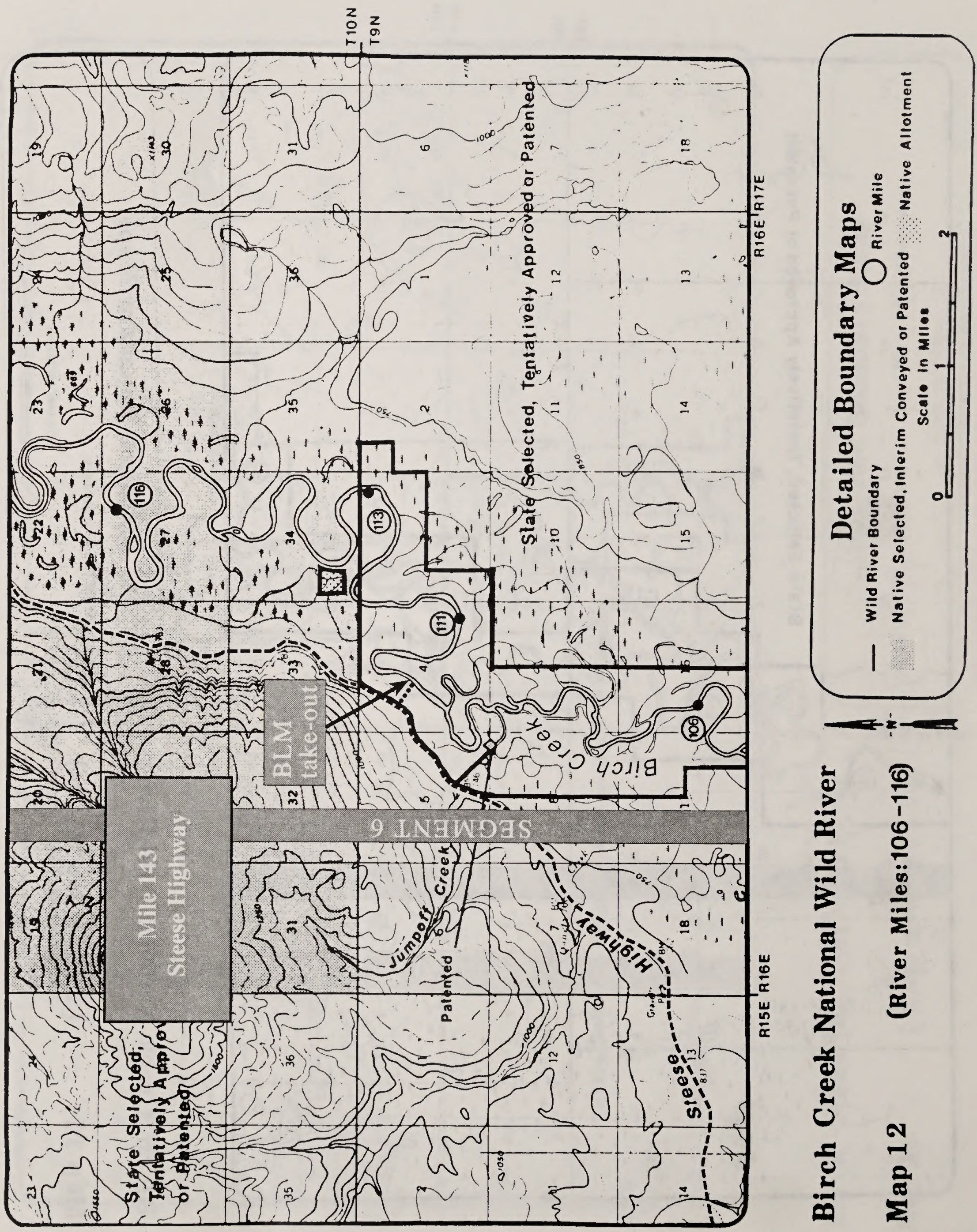




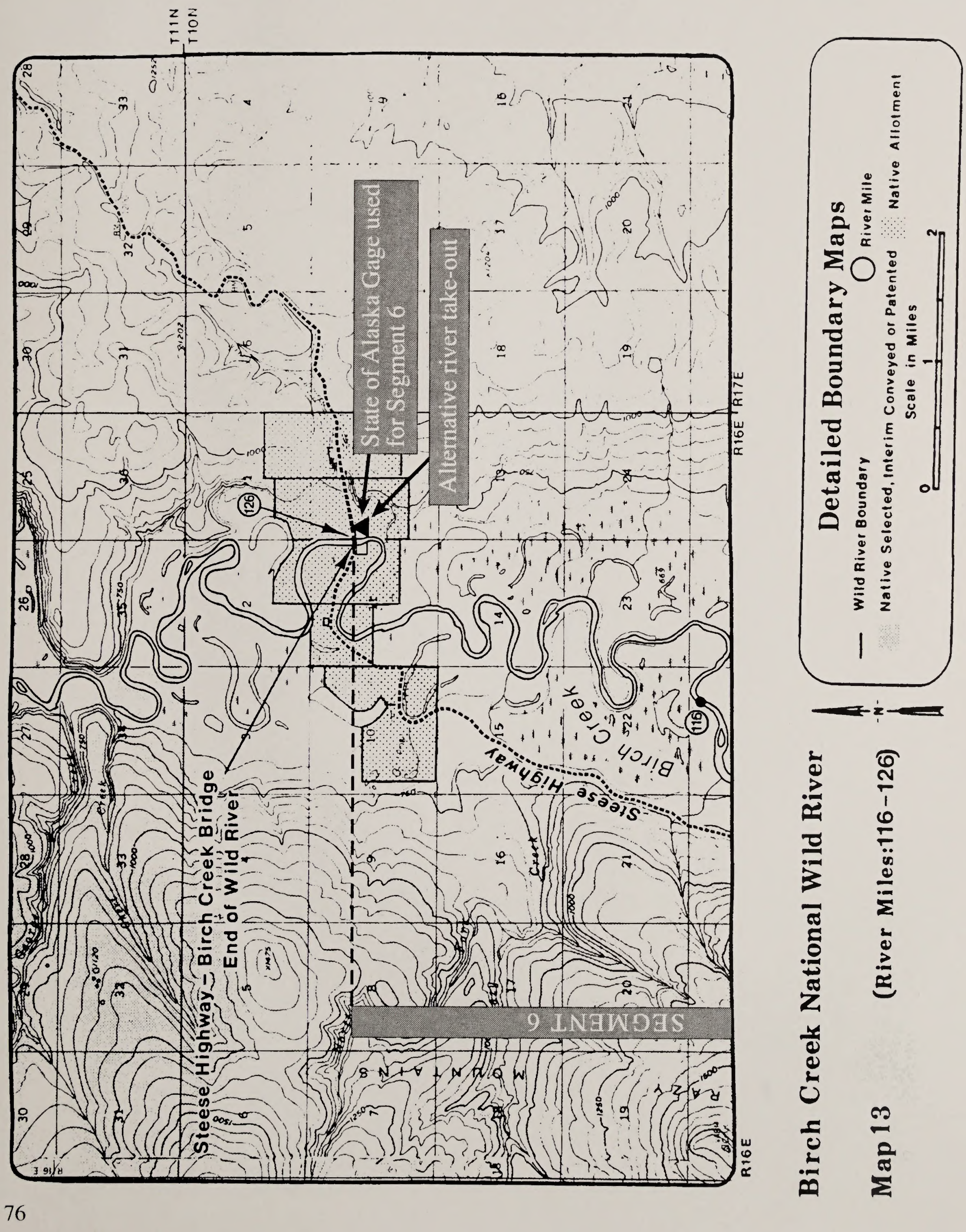





\section{BLM LIBRARY \\ BLDG 50, ST-150A \\ DENVER FEDERAL CENTER \\ P.O. BOX 25047 \\ DENVER, COLORADO 80225}


